\title{
BIOGAS HARVESTING FROM ANAEROBICALLY DIGESTED FOOD WASTE: A REVIEW
}

\author{
SABIANI, N. H. M. ${ }^{{ }^{*}}-$ TAJARUDIN, H. A. ${ }^{2}$ \\ ${ }^{1}$ School of Civil Engineering, Universiti Sains Malaysia, 14300 Nibong Tebal, Pulau Pinang, \\ Malaysia
}

${ }_{2}^{2}$ School of Industrial Technology, Universiti Sains Malaysia, 11800 USM, Penang, Malaysia

(phone: +60-46-536-194; fax: +60-46-536-375)

${ }^{*}$ Corresponding author

e-mail: cenoor@usm.my; phone: +60-45-996-228; fax: +60-45-996-906

(Received $3^{\text {rd }}$ May 2021; accepted $20^{\text {th }}$ Sep 2021)

\begin{abstract}
Food waste (FW) is the largest and most problematic organic waste component in the solid waste management system around the world including Malaysia. In promoting renewable energy production, FW has enormous potential and is one of the most promising sources as it can be converted into energy due to high organic matter content found in this source. Improper handling of FW has adverse effects on humans and the environment. FW that ends up in landfills is capable of producing greenhouse gases such as methane and carbon dioxide which can lead to increased atmospheric temperature, climate change, and global warming as well as causing serious health hazards. Compared to landfilling, incineration, and composting, anaerobic digestion (AD) is considered the best treatment alternative in FW management. This paper reviews the efficacy of using FW AD for energy production, focusing on the critical factors influencing the digestion process, the characteristics of the FW and their impact on the AD process, and the method of anaerobic conversion of FW (batch or continuous) to methane. To enhance the AD of FW, the co-digestion and pretreatment method will also be discussed further in this review paper.
\end{abstract}

Keywords: anaerobic digestion, food waste, energy, methane, co-digestion, pretreatment, factors influencing anaerobic digestion process

\section{Introduction}

Food waste $(\mathrm{FW})$, which is known as a complex heterogeneous organic material consisting of highly recalcitrant material up to extremely biodegradable compounds has become a major global problem. In the United States, the generation of FW has reached $188 \mathrm{~kg} /$ capita per year with total losses reaching $\$ 165.6$ billion at consumer and retail levels (Abd Ghafar, 2017). According to Liu et al. (2021), the annual food loss per capita in North America and Europe is $280-300 \mathrm{~kg}$. Furthermore, approximately $33 \%$ of food is wasted in Southeast Asia (Yang et al., 2016). According to Kamaruddin et al. (2017), Malaysia presently produces around $1.1 \mathrm{~kg} / \mathrm{capita} /$ day of municipal solid waste (MSW) where about $40 \%$ of MSW consists of $\mathrm{FW}$. The remaining $60 \%$ is comprised of inorganic waste such as plastics, papers, diapers/napkins, textile, metal, glass, rubber and leather, garden or yard waste, and others (SWCorp, 2016). Approximately, 77\% of the FW produced consists of cooked rice, noodles, bread, and pastries (carbohydrate group) produced by cafeterias, commercial restaurants, meat, and market industries (Tanimu et al., 2014). Most of the polymeric carbohydrates and proteins are present in solid form, for example, rice, bread, noodles, vegetables, and meat. The composition of FW discarded from the households and foodservice level comprising restaurants, canteens, and others can be varied. In countries like Europe and Asia, the largest composition of FW produced is vegetables and fruits with a percentage of $40 \%$ and $56 \%$, respectively. The rest consists 
of pasta and bread, rice, dairy products, meat, and fish. In general, the FW generated comprises $41-62 \%$ of degradable carbohydrate, $15-25 \%$ protein, and followed by $13-30 \%$ of lipids (Braguglia et al., 2018). In addition, for many countries in Southeast Asian continent such as Malaysia and Thailand, the largest composition of FW is dominated by carbohydrates groups such as cooked or uneaten rice, noodles, and bread. Meanwhile, proteins and lipids are typically derived from FW comprising meat, fish, eggs, and oily gravy.

Ineffective FW disposal will contribute to severe environmental problems including odour emission, leachate production, greenhouse gas emissions (GHG), and groundwater pollution (Zhou et al., 2018). Landfilling, incineration, and aerobic composting are some of the traditional approaches that are often taken into consideration in FW management in Malaysia. Several factors make these three methods unfavourable to dispose of FW, namely the tendency to create environmental problems, space constraints, and characteristics of FW. In FW management, anaerobic digestion (AD) is considered the best alternative of treatment compared to landfilling, incineration, and composting. Limited environmental impacts and a high potential for energy recovery make this technology best suited for treating FW (Ariunbaatar et al., 2014) as well as having great potential in reaching 40 to $60 \%$ of waste reduction. Anaerobic digestion is a biological process that takes place in the absence of oxygen and results in the destruction and stabilization of organic waste (Negri et al., 2020), involving 4 stages of processes namely hydrolysis, acidogenesis, acetogenesis, and methanogenesis (Zhou et al., 2018; Negri et al., 2020). This method offers several environmental benefits over other forms of treatment technology, for example, it reduces greenhouse gas emission (methane and carbon dioxide), reduces odors, and produces sanitized nutrient-rich fertilizer (Seruga, 2021).

This paper will discuss the anaerobic conversion of FW for energy production, particularly methane. The focus will be given to the critical factors influencing the digestion process, the characteristics of the FW, and their impact on the AD process. Further explanation will be given to the anaerobic conversion of FW into methane either by batch or continuous AD method. Methods to enhance the AD of FW such as codigestion and pretreatment will also be evaluated further.

\section{Anaerobic digestion}

Biogas is the most important product in the anaerobic digestion process. Biogas is a combustible gas, and the quality is defined by its composition. The main composition of biogas consists of $\mathrm{CH}_{4}$ and $\mathrm{CO}_{2}$. In addition, small quantities of other gas components are also present in the biogas produced through the anaerobic digestion process which includes nitrogen $\left(\mathrm{N}_{2}\right)$, hydrogen $\left(\mathrm{H}_{2}\right)$, hydrogen sulfide $\left(\mathrm{H}_{2} \mathrm{~S}\right)$, ammonia $\left(\mathrm{NH}_{3}\right)$, oxygen $\left(\mathrm{O}_{2}\right)$, and water vapour $\left(\mathrm{H}_{2} \mathrm{O}\right)$. According to Bharathiraja et al. (2018), biogas is largely made up of methane $\left(\mathrm{CH}_{4}\right)(40-75 \%)$ and carbon dioxide $\left(\mathrm{CO}_{2}\right)(15-60 \%)$, with minor amounts of hydrogen $\left(\mathrm{H}_{2}\right)$, nitrogen $\left(\mathrm{N}_{2}\right)(0-5 \%)$, hydrogen sulfide $\left(\mathrm{H}_{2} \mathrm{~S}\right)(0-5000 \mathrm{ppm})$, oxygen $\left(\mathrm{O}_{2}\right)(2 \%)$, water $\left(\mathrm{H}_{2} \mathrm{O}\right)(1-5 \%)$, and saturated hydrocarbons (i.e. ethane, propane). Furthermore, the anaerobic digestion process is becoming popular nowadays because of its methane recovery potential, and the nutrient-rich solids produced following digestion (digestate) can be utilized as fertilizer. Waste stabilization is demonstrated by the generation of methane and carbon dioxide at the end of the anaerobic digestion process. 
The anaerobic process begins with hydrolysis where complex organic materials will be hydrolyzed to a smaller size and soluble organic substrate. Meanwhile, in acidogenesis stage, amino acids, simple sugars, and long-chain fatty acids have been broken down into short-chain fatty acids. In the third stage (acetogenesis), the simple molecules from acidogenesis are further digested to produce carbon dioxide, hydrogen, and mainly acetic acid. Then, methanogenesis stage will take place in which the carbon dioxide and hydrogen are converted into methane gas.

\section{Critical factors influencing anaerobic digestion}

In order to ensure the operation of the anaerobic digestion process occurs in optimum conditions, there are a few parameters that should be taken into consideration and controlled. Therefore, any drastic changes in the parameters involved in the anaerobic digestion system will affect the chain reaction that ultimately inhibits the digestion process. Complete microbial metabolic processes, which entail intricate interactions of various types of bacteria, must be in continual equilibrium to ensure the digester remains stable. Physiology, nutritional needs, growth kinetics, and sensitivity to environmental conditions are the important characteristics that distinguish between the acid-forming and methane-forming microorganisms in the anaerobic digestion system. The instability of an anaerobic digester is caused by the failure to ensure a balance between these two groups of microorganisms ( $\mathrm{Li}$ et al., 2018). Thus, parameters such as temperature, $\mathrm{pH}$ and alkalinity, volatile fatty acids (VFA), mixing, hydraulic retention time (HRT), and organic loading rate (OLR) must be observed and maintained within the permitted range to enhance microbial activity and thus boost the efficiency of the anaerobic decomposition of organic matter in the system.

\section{Temperature}

Anaerobic digestion (AD) can function over a large range of temperatures. Temperature is one of the important operating parameters in determining the performance of $\mathrm{AD}$ reactor to ensure the survival and optimum development of microbial consortium. Bacteria have two optimum temperature ranges known as mesophilic and thermophilic although they can survive in a wide range of temperatures. Anaerobic digesters are discovered to be operated at temperatures ranging from $20{ }^{\circ} \mathrm{C}$ to $60{ }^{\circ} \mathrm{C}$. Mesophilic $\left(20-40{ }^{\circ} \mathrm{C}\right)$ and thermophilic $\left(50-65^{\circ} \mathrm{C}\right)$ temperature ranges are responsible for methane generation, with optimum temperatures of $35{ }^{\circ} \mathrm{C}$ and $55^{\circ} \mathrm{C}$, respectively (Panigrahi and Dubey, 2019). The value of the optimum temperature for the anaerobic digestion process is different and it depends on the composition of the feedstock and type of digester used. Since the rate of digestion is greatly affected by temperature, it is considered a critical parameter that must be maintained in the desired range. Anaerobic bacteria can survive in a wide temperature range, from low temperatures (freezing point) until reaching a temperature of $70{ }^{\circ} \mathrm{C}$. However, the most significant development is in the two ranges of temperature from $25{ }^{\circ} \mathrm{C}$ to $40{ }^{\circ} \mathrm{C}$ (mesophilic) and from $50{ }^{\circ} \mathrm{C}$ to $65{ }^{\circ} \mathrm{C}$ (thermophilic). The active microbial community structure is different at both optimum temperatures. The temperature range had a significant influence on the transition of the reactor's methanogenic activity from mesophilic to thermophilic, as evidenced by the sudden performance deterioration and complete cessation of methane recovery when the temperature range was increased from mesophilic to thermophilic (Kim and Lee, 2016).

The optimum temperature setting $\left(35^{\circ} \mathrm{C}\right)$ during mesophilic anaerobic digestion of FW has successfully produced a high methane yield. This is evidenced through a study 
conducted by Wang et al. (2014), Gou et al. (2014), Dai et al. (2013), Shen et al. (2013), Ratanatamskul and Manpetch (2016), Drennan and Di Stefano (2014), Wu et al. (2016) and Paudel et al. (2017). The range of methane yield recorded through their study was between 153-620 L CH$/ \mathrm{kgVS}$. In addition, the setting of the optimum temperature $\left(55^{\circ} \mathrm{C}\right)$ during thermophilic anaerobic digestion of $\mathrm{FW}$ also produced a high methane yield. Some researchers such as Castrillon et al. (2013), Gou et al. (2014), Yang et al. (2015), Nagao et al. (2012), and Qiang et al. (2013) have recorded high methane yield production (178-475 $\left.\mathrm{L} \mathrm{CH}_{4} / \mathrm{kgVS}\right)$. However, the increase in methane yield produced does not only depend on the setting of the optimum temperature during the process alone. Factors such as $\mathrm{pH}$ and co-digestion of the $\mathrm{FW}$ with other substrates also contributed to the increase in methane yield.

In comparison to mesophilic digestion, thermophilic digestion results in a greater reduction of pathogens in the digested substrate, a higher specific growth rate of microorganisms, a shorter hydraulic retention time (HRT), and a faster rate of biogas production (Fernandez-Rodriguez et al., 2013; Cavinato et al., 2013). According to the Arrhenius equation, increasing the reaction temperature by $10^{\circ} \mathrm{C}$ doubles the rate of many chemical processes (Panigrahi and Dubey, 2019). The specific gas production and gas production rate rose from 0.34 to $0.49 \mathrm{~m}^{3} / \mathrm{kgVS}$ and $0.53-0.78 \mathrm{~m}^{3} / \mathrm{m}^{3}$ day, respectively, as the temperature climbed from 37 to $55{ }^{\circ} \mathrm{C}$ (Cavinato et al., 2013). In the thermophilic process, on the other hand, the high rate of acidogenesis leads to an buildup of propionic acid in the digester, which may limit methanogen activity. Another issue with thermophilic AD is its greater energy demand and process instability, both of which can have a negative impact on energy balance and the entire digestion process (Beevi et al., 2015). The benefits of thermophilic (increased hydrolysis and conversion rates) and mesophilic (elevated process stability, better effluent quality) conditions were combined to develop temperature phased AD (TPAD) (Fuess et al., 2018). TPAD consists of two stages: a shorter thermophilic pretreatment phase and a subsequent mesophilic phase with a longer retention duration. The thermophilic stage accelerates hydrolysis and acidogenesis, which seem to be the rate-limiting processes in anaerobic digestion whereas the mesophilic stage maintains constant conditions for syntrophic acetogenesis and methanogenesis owing to methanogens' superior resistance to inhibitory or toxic chemicals (Borowski, 2015). According to Borowski (2015) and Akgul et al. (2017), TPAD can improve volatile solids and total coliform degradation, enhance methane production and organic loading rates (OLR), increase operational stability and effluent quality in terms of volatile fatty acids (VFA) and soluble chemical oxygen demand (SCOD), and lowering hydraulic retention times (HRT) for total coliform degradation. It has the same potential as single-stage thermophilic anaerobic digestion, but it is much more efficient than single-stage mesophilic anaerobic digestion. The TPAD has been used to digest sewage sludge, FW, the organic fraction of municipal solid waste (OFMSW), as well as a solid residue from olive mills. The TPAD of FW is capable of producing high methane yields as reported by Ventura et al. (2014), Yeshanew et al. (2016), Wu et al. (2016), and Li et al. (2020). Ventura et al. (2014) have conducted TPAD of FW from a recycling company using a combination of mesophilic-thermophilic (10L: 30L) and thermophilic-mesophilic (10L: 30L) reactors. They found that the methane yields obtained were 440 and $370 \mathrm{~L} \mathrm{CH}_{4} / \mathrm{kg} \mathrm{VS}_{\text {added, }}$ respectively using a combination of mesophilic-thermophilic and thermophilic-mesophilic reactors. Yeshanew et al. (2016) reported that approximately $334.7 \mathrm{~L} \mathrm{CH}_{4} / \mathrm{kg} \mathrm{COD}_{\text {removed }}$ of methane yield was produced through the TPAD process of synthetic FW using a combination of continuously stirred 
tank reactor (CSTR) and anaerobic baffled reactor (ABR) with recirculation. Wu et al. (2016) used a combination of the thermophilic-mesophilic reactor with a capacity of 10L to digest food waste with de-oiled grease trap waste and found that a total of $520 \mathrm{~L} \mathrm{CH}_{4} / \mathrm{kg}$ $\mathrm{VS}_{\text {added }}$ of methane yield was produced. Li et al. (2020) reported that two temperaturephased anaerobic digestion (TPAD) systems, non-recirculation temperature-phased anaerobic digestion (NR-TPAD) and recirculation temperature-phased anaerobic digestion (R-TPAD), were operated in parallel for the co-digestion of FW and paper waste $\left(55^{\circ} \mathrm{C}\right.$ in the first reactor and $35^{\circ} \mathrm{C}$ in the second reactor). The range of methane content obtained through these two systems is between 53.99-59.23\% and 56.14-60.28\% respectively, using NR-TPAD and R-TPAD. Recirculation had a big impact on the microbial population's composition and variations. Recirculation promotes phase separation in the R-TPAD system, converting lactic acid to hydrogen in the first reactor, and has been shown to enhance co-digestion of food waste and paper waste, resulting in methane production. However, the utilization of the TPAD system does not all produce the expected results. For example; Xiao et al. (2018) found methane yield produced through the TPAD system was lower (454 L CH4/kg VSadded) compared to single mesophilic AD (477 $\mathrm{L} \mathrm{CH}_{4} / \mathrm{kg} \mathrm{VS}_{\text {added }}$ ) and single thermophilic AD system (461 L $\mathrm{CH}_{4} / \mathrm{kg} \mathrm{VS}$ added). The TPAD employed in the test resulted in a lower biogas and methane production rate and yield, but a greater biogas and methane recovery rate than the two single-stage anaerobic digestion systems. The methane recovery rate for TPAD, single mesophilic $\mathrm{AD}$, and single thermophilic $\mathrm{AD}$ systems is 577,574 , and $564 \mathrm{~L} \mathrm{CH}_{4} / \mathrm{kg}$ $\mathrm{VS}_{\text {degraded, }}$, respectively.

\section{pH and alkalinity}

For optimum growth, each group of anaerobic microorganisms involved in the anaerobic digestion process has a specific optimum $\mathrm{pH}$, therefore $\mathrm{AD}$ is strongly dependent on the $\mathrm{pH}$ of the system. In order to ensure the success of the operation and stability of an anaerobic digester, this parameter must be monitored and maintained. According to Parawira (2004), the utilization of carbon and energy sources, efficiency of substrate dissimilation, synthesis of protein and various types of storage material, and release of metabolic products of cells are among a few aspects that are influenced by $\mathrm{pH}$. Since fermentative microorganism is less sensitive to changes, then it can work in a wider $\mathrm{pH}$ range. The acetogenesis phase necessitates a $\mathrm{pH}$ of $6.5-7$, which is near neutral to acidic. A slightly acidic and basic $\mathrm{pH}$ of 6 and 7.5 are essential for hydrolysis and methanogenesis, respectively (Leung and Wang, 2016). The literature has indicated a range of $\mathrm{pH}$ values (6.5-8.5) for anaerobic digestion, although the ideal $\mathrm{pH}$ for an efficient anaerobic digestion process is about 7 (Kumar and Samadder, 2020). A decline in $\mathrm{pH}$ (below 6) significantly reduces the activity of the methanogens more than that of the acidogens and causes volatile fatty acids (VFAs) formation (Panigrahi and Dubey, 2019), which could inhibit the whole process and contributed to digester instability (Kumar and Samadder, 2020). Alkalinity can be defined as a measurement of the chemical buffering capacity of an aqueous solution. Agbalakwe (2011) states that to ensure the operation of an anaerobic digester is in stable condition, the digester needs to provide adequate buffering capacity to maintain the $\mathrm{pH}$ of the system to be in the range of 6.7 to 7.4 by neutralizing the VFA which may present in the system. The presence and concentration of buffering compounds are influenced by the composition of the total organic load and substrate. Several compounds provide significant buffering capacity in the anaerobic digestion process such as hydrogen sulfide $\left(\mathrm{H}_{2} \mathrm{~S}\right)$, ammonia $\left(\mathrm{NH}_{3}\right)$, bicarbonate $\left(\mathrm{H}_{2} \mathrm{CO}_{3}\right)$, 
and di-hydrogen phosphate. An anaerobic treatment system has its buffering capacity against $\mathrm{pH}$ drop. Alkalinity in the form of $\mathrm{CO}_{2}, \mathrm{NH}_{3}$, and $\mathrm{H}_{2} \mathrm{CO}_{3}$ is produced by methanogenic bacteria. According to Appels et al. (2008), the concentration of $\mathrm{CO}_{2}$ in the gaseous state and bicarbonate $\left(\mathrm{H}_{2} \mathrm{CO}_{3}\right)$ alkalinity in the liquid state play a huge role in controlling the $\mathrm{pH}$ system. The addition of bicarbonate alkalinity (in the liquid phase) will increase the $\mathrm{pH}$ if the concentration of $\mathrm{CO}_{2}$ (in the gas phase) is constant.

According to Zamri et al. (2021), the optimum $\mathrm{pH}$ ranges for acidogenesis and methanogenesis are 5.5 to 6.5 and 6.5 to 8.2 , respectively. Optimum $\mathrm{pH}$ values for high methane yield recovery in $\mathrm{AD}$ have been discovered in several studies. According to Liu et al. (2008), the optimum $\mathrm{pH}$ range for OFMSW biogas yield in $\mathrm{AD}$ is 6.5-7.5. The optimal $\mathrm{pH}$ range for methanogenesis utilizing Korean FW leachate was 6.5-8.2 (Lee et al., 2009). Meanwhile, when anaerobic digestion was performed on FW obtained from the hostel mess of the National Institute of Technology Calicut, Kerala, India, Jayaraj et al. (2014) discovered that biogas yield and degradation efficiency were significantly higher for the substrate of $\mathrm{pH} 7$ compared to other $\mathrm{pH}$ values. The methane content of biogas produced at $\mathrm{pH} 7$ was found to be $60.8 \%(\mathrm{v} / \mathrm{v})$. The cumulative biogas production over a 30-day retention period at the same $\mathrm{pH}$ was measured at $5655 \mathrm{~mL}$. The results, however, vary depending on the characteristics of the OFMSW and the acid conditions. Alkali-based chemicals such as sodium bicarbonate $\left(\mathrm{NaHCO}_{3}\right)$, sodium carbonate $\left(\mathrm{Na}_{2} \mathrm{CO}_{3}\right)$, calcium hydroxide $\left(\mathrm{Ca}(\mathrm{OH})_{2}\right)$, and sodium hydroxide $(\mathrm{NaOH})$ were added to the reactor during the start-up period to maintain the $\mathrm{pH}$ stability for the continuous process, and $\mathrm{NaOH}$ is most efficacious in enhancing the AD process (Kondusamy and Kalamdhad, 2014; Jain et al., 2015). Before the reactors are fed, neutralization is required if the anaerobic digestion feedstock has a very high or low pH (Kouzi et al., 2020; Zamri et al., 2021). According to Zhang et al. (2009), hydrolysis and $\mathrm{pH}$ have also been found to have a strong positive correlation $(\mathrm{P}=0.01)$. Therefore, the hydrolysis rate constant is inferred to depend on the $\mathrm{pH}$. Both methanogenic and acidogenic microorganisms have optimum $\mathrm{pH}$ levels, which should be highlighted. $\mathrm{pH}$ 6.5-8.2 is optimum for methanogenesis, while 7.0 is the most efficient pH (Lee et al., 2009). Methanogens' growth rate is considerably lowered at $\mathrm{pH}$ values below 6.6, and methanogenic bacteria's activity is inhibited at higher or lower $\mathrm{pH}$ levels (Mao et al., 2015). Because the optimal $\mathrm{pH}$ for acidogenesis was between 5.5 and 6.5, a two-stage AD process splitting the hydrolysis-acidification and acetogenesis-methanogenesis processes is the recommended mode of operation (Mao et al., 2015).

The equilibrium of $\mathrm{CO}_{2}$ and bicarbonate ions is known as buffering capacity. Direct $\mathrm{pH}$ measurement is less reliable than buffering capacity in determining digester imbalance. VFAs are formed during the acidogenesis phase, and the $\mathrm{pH}$ inside the digester is decreased. Methanogens, which produce alkalinity in the form of $\mathrm{CO}_{2}$ and bicarbonate, counteract this $\mathrm{pH}$ drop. The concentration of $\mathrm{CO}_{2}$ in the gas phase and the bicarbonate in the liquid phase govern the $\mathrm{pH}$ inside the digester. Lowering the OLR, applying salts to turn $\mathrm{CO}_{2}$ to bicarbonate, or simply adding bicarbonate can all help with inadequate buffering capacity (Panigrahi and Dubey, 2019). The food/microorganism (F/M) ratio also can be altered to adjust for insufficient buffer capacity. It is typically recommended that alkalinity be kept around 1000 and $5000 \mathrm{mg} \mathrm{CaCO}_{3} / \mathrm{L}$ to maximize methane production (Tchobanoglous et al., 2003). 


\section{Volatile fatty acids (VFA)}

In an anaerobic digestion monitoring process, volatile fatty acids (VFA) concentration is one of the parameters that play an important role that causes toxicity and reactor failure. VFA consisting of acetic, propionic, butyric and valeric acid is an intermediate compound produced during the acidogenesis stage. The presence of VFA in the anaerobic digestion process can reduce the production of methane gas. The effect of fermentation digestion can be seen as a result of an increase in acid concentration in the system. In case of uncontrolled accumulation of acid, hydrogen exists in the anaerobic digestion process will play an important role in preventing the formation of methane gas. According to Mao et al. (2015) and Jin et al. (2021), methanogenesis inhibition can occur in anaerobic digestion if the VFA produced has a high concentration. The dissociated form of VFA is dominant at elevated $\mathrm{pH}$, while at low $\mathrm{pH}$ the undissociated VFAs (free volatile fatty acids) are dominant (Forgacs, 2012). According to Deublein and Steinhauser (2008), the ability of undissociated VFAs to diffuse into cells and denatured the proteins can cause inhibiting effect. The best indicator of the most sensitive metabolic group of microbial groups in the anaerobic system usually refers to the concentration of acetic, propionic, and butyric acids (Lee et al., 2015). In anaerobic digestion, acetic acid normally presents in much higher concentrations than the other types of fatty acids (Lee et al., 2015). Sabri et al. (2018) explain that the conversion rate of VFA to methane varies according to the sequence of acetic acid > ethanol> butyric acid> propionic acid. Lactic acid is an undesirable terminal fermentation product and this acid has the potential to be converted into propionic acid. Propionic acid which accumulates during anaerobic digestion will lead to failure in the production of methane gas (Mamimin et al., 2017).

VFAs regulate $\mathrm{pH}$, which is one of the most critical factors in AD. Fermentative bacteria require a $\mathrm{pH}$ range of $4.0-8.5$, whereas methanogens prefer a limiting $\mathrm{pH}$ range of 6.5-7.2 (Zhang et al., 2014). Previous studies have shown that the $\mathrm{pH}$ of anaerobic digesters has a substantial impact on VFAs: at low $\mathrm{pH}$, acetic and butyric acids are the predominant VFAs, but at $\mathrm{pH}$ 8.0, acetic and propionic acids play a prominent role (Appels et al., 2011). Furthermore, $\mathrm{pH}$ control can influence both the type and amount of acid-producing bacteria (Horiuchi et al., 2002). The generation and accumulation of volatile fatty acids (VFAs) have been found to impede and harm the digestion process, resulting in delayed biogas production (Labatut et al., 2011; Vijayaraghavan et al., 2012). According to Paritosh et al. (2017), the inhibition of VFAs on methanogen activity is produced by a $\mathrm{pH}$ drop, which may result in acid-sensitive enzyme activity loss. Macromolecules can be destroyed by large amounts of undissociated acids that can penetrate cellular membranes. Solid-state food waste anaerobic digestion might produce VFA concentrations of up to $20,000 \mathrm{mg} / \mathrm{L}$, which is significantly greater than a wastewater anaerobic process. VFAs vary from 2000 to $3000 \mathrm{mg} / \mathrm{L}$ in the optimal conditions for metabolic activity (Paritosh et al., 2017). According to Lee et al. (2015), VFA concentrations in field anaerobic digestion facilities processing FW leachate should be kept below 4,000 mg/L to achieve the Korean guideline of $65 \%$ VS removal rate. The concentrations of VFA should be employed as a key operational parameter for controlling and managing the anaerobic digestion process. To ensure the success of anaerobic digestion processes in which high methane yields can be produced as well as prevent inhibition from occurring, the VFA content must be controlled to be within the optimal range. The $\mathrm{pH}$ control needs to be done throughout the digestion process. 


\section{Mixing strategy}

Mixing is one of the important factors in the production of biogas during the AD process. Increasing the contact between substrate and microorganisms is the main objective to carry out the mixing process in the digester. Mixing will uniformly distribute heat and bacteria in the digester to prevent the formation of scum and the occurrence of temperature gradients in the digester. In addition to maintaining a more uniform temperature in the digester, mixing can also help to release the resulting biogas during the AD process. Substrates that have been introduced into the digester should be mixed at regular intervals to prevent settling as well as maintaining contact between bacteria and substrate. Mixing aids in achieving substrate homogeneity and uniform distribution of nutrients, $\mathrm{pH}$, and temperature in the digester, as well as assisting in the release of trapped biogas in the digestate (Singh et al., 2020).

A slow or minimal mixing process is preferable rather than vigorous and excessive mixing. Vigorous continuous mixing process will disrupt the structure of microbial flocs, which consequently interfere with the syntrophic relationships between microorganisms in the digester which will ultimately affect the reactor performance (Singh et al., 2020). When compared to vigorous continuous mixing, Lindmark et al. (2014) found that minimal mixing intensities boosted biogas production rate and overall volume produced. Kariyama et al. (2018) reported that excellent performance is achieved (high biogas production rates and specific gas production) when minimal mixing is used in the digestion of livestock manure. Mechanical mixers, recirculation of digester contents, or recirculation of the produced biogas to the bottom of the digester using pumps are a few methods used to mix the organic material in the digester during the AD process (Mao et al., 2019). To ensure that the solids are in suspension, mechanical or gas mixers can be used for mixing the organic material in the digester. One of the inexpensive methods to enhance the movement of organic materials in the digester is by bubbling the biogas through the chamber. Recirculation of waste is another mixing method in which the digestate produced at the end of the AD process will be removed and only certain percentages will be fed into the digester along with the fresh substrate. This action aims to inoculate the fresh substrate fed into the digester with the bacteria and thus increase the movement in the digester and avoid the formation of the scum layer.

Mixing is a major difficulty in attaining good digestion performance, especially in dry AD (TS $>10 \%)$, because a thick slurry like food waste slurry requires more energy input to homogenize the feedstock. Mechanical mixing outperforms gas circulation and pumped circulation, according to a comparison of the three mixing methods (Panigrahi and Dubey, 2019). During startup and shock loads in combination with higher mixing intensities, instabilities in the anaerobic digestion process, the buildup of volatile fatty acids (VFAs), and decreased gas generation were detected (Lindmark et al., 2014). Shear stress is caused by high mixing intensity, which can decrease and disintegrate flock formations, as well as reduce biogas generation. Higher mixing intensities also impact the microbial community's composition by boosting VFA concentrations during startup and shock loads, hence increasing the relative competitiveness of certain acetate-degrading bacteria (Lindmark et al., 2014). Lowering the mixing intensity can aid in digester stabilization. Biogas yield has been demonstrated to increase during mixing in contrast to unmixed digesters for greater organic loadings and TS concentrations, whereas mixing is less significant at lower loadings (Karim et al., 2005). Changing from a continuous to an intermittent mixing regime can also help enhance biogas production (Kaparaju et al., 2008). 
Lindmark et al. (2014) compared three different mixing intensities for a fresh substrate of the organic fraction of municipal solid waste (OFMSW), i.e. $150 \mathrm{rpm}$ and $25 \mathrm{rpm}$ continuous mixing and minimally intermittent mixing, to the effect of mixing intensity on biogas production and energy efficiency of the biogas plant (OFMSW). The results show that a lower mixing intensity leads to a higher biogas production rate and higher total biogas production in both cases. After process stability, $25 \mathrm{rpm}$ continuous mixing and minimally intermittent mixing produced equivalent amounts of biogas, however, 150 rpm continuous mixing produced lesser biogas throughout the trial. During digestion, cumulative biogas generation was $295 \pm 2.9,317 \pm 1.9$, and $304 \pm 2.8 \mathrm{NmL} / \mathrm{g} \mathrm{VS}$ added until day 31. In addition to improving gas generation, optimal mixing can increase the anaerobic digestion process' energy efficiency.

\section{Hydraulic retention time ( $H R T)$}

One of the most important design parameters that affect the economics of anaerobic digestion is hydraulic retention time (HRT) (Ta et al., 2020). A shorter HRT reduces the size of the digester for a given waste volume, thus reducing the capital cost. Depending on the substrate types and process parameters, the HRT of a digester can range from a few days to months. A longer retention duration typically results in higher cumulative methane production as well as a lower total VS reduction. Microbes can adapt to toxic compositions by having a lengthy retention duration. For a longer HRT, a large digester volume would be required, as a short retention period could result in the microbial washout, leading to a low methane yield (Panigrahi and Dubey, 2019). The rate of microbe loss may outweigh the rate of bacterial growth in the case of a short HRT, causing the anaerobic digestion process to fail. A short HRT also caused VFAs to build up in the digester (Pan et al., 2021). HRT measures the time taken by the substrate or feedstock to stay in the digester. HRT can be calculated using Equation 1.

$$
\operatorname{HRT}=\frac{V}{Q}
$$

where, HRT denotes the hydraulic retention time (days), $\mathrm{V}$ denotes the working volume $\left(\mathrm{m}^{3}\right)$, and $\mathrm{Q}$ denotes the flow rate $\left(\mathrm{m}^{3} /\right.$ day).

Several researchers agree that the HRT for mesophilic digesters is longer (15-30 days) (Mao et al., 2015) compared to the thermophilic digesters with a shorter HRT range between 12-14 days (Arsova, 2010). Though, some AD process requires longer HRT. For example, as reported by Owamah and Izinyon (2015) and Bhatia et al. (2021), the HRT between 50-100 days was required to decompose the solid waste generated from the feedstock from fibers and lignocellulose-containing plants. Owamah and Izinyon (2015) reported that the HRT for anaerobic digestion process of food waste and maize husk is 68 days and produces cumulative methane production of about $400 \mathrm{LCH}_{4} / \mathrm{kgVS}$. Meanwhile, Bhatia et al. (2021) recorded an HRT of 120 days to decompose a lignin-rich plant (Ludwigia grandiflora) and produced an average biogas yield of $265 \mathrm{LCH}_{4} / \mathrm{kgVS}$. Meanwhile, Arsova (2010) points out that longer HRT can be observed in AD processes using high solid content systems or dry digestion compared to low solid content systems or also known as wet digestion. Normally, the HRT range for dry digestion is between 14-30 days, while the HRT range is as low as 3 days for wet digestion. The decomposition of organic material inside the digester will become more complete if the substrate is allowed to have a longer HRT. The substrate in the reactor that has uniform HRT can be 
observed in a continuously mixed digester. Different microbial communities that grow in the digesters function according to their respective HRT. In a continuously mixed digester, the minimum HRT is determined by the growth rate of the slowest growing, an important microorganism in the anaerobic bacterial community. Nevertheless, the reaction rate will decrease with HRT. This suggests that there is an optimum retention time that will allow the AD process to completely occur while reducing operational costs. The HRT has been identified as a significant parameter that may influence bacteriological ecology (Siddique et al., 2016). The HRT must be optimized for each waste mixture introduced into the system (Anggarini et al., 2015).

There are several examples of studies involving the influence of HRT on biogas production during anaerobic digestion of food waste as conducted by Kim et al. (2006), and Liu et al. (2018). The effects of temperature and hydraulic retention time (HRT) on methanogenesis were investigated by Kim et al. (2006). The operating temperature was varied between $30^{\circ} \mathrm{C}$ and $55^{\circ} \mathrm{C}$, with HRTs ranging from 8 to 12 days. Thermophilic digesters were shown to remove more sCOD from liquid food waste than mesophilic digesters. Regardless of HRT, the rates of biogas and methane production in thermophilic digesters were higher than those in mesophilic digesters. Although a 10-day HRT produced the most biogas, a 12-day HRT yielded the most methane $\left(223 \mathrm{LCH}_{4} / \mathrm{kg}\right.$ $\left.\mathrm{sCOD}_{\text {degraded }}\right)$ in the reactor. This suggests that longer HRTs can produce more biogas. Nevertheless, when 8-day HRT was used, digestion stability showed a decrease. By varying process parameters such as hydraulic retention time (HRT) and organic loading rate (OLR), Liu et al. (2018) observed the biogasification performance of food waste. Using a continuously stirred tank reactor (CSTR), they experimented with two operating conditions: R1 (fixed HRT and OLR) and R2 (varying HRT and OLR) for 116 and 92 days, respectively. They discovered that food waste was anaerobically digested with CSTR under two distinct circumstances, producing the highest biogas generation of $787 \mathrm{~mL} / \mathrm{g}$.day achieved at $2.25 \mathrm{~g} / \mathrm{L}$.day with a fixed HRT of 30 days. OFMSW (including food waste) comprises a high concentration of carbohydrate, cellulose, protein, lipid, and fat components, necessitating a longer HRT (Zamri et al., 2021). Longer HRTs can result in higher biogas production. The shorter HRT is advantageous because it directly corresponds to production costs and process efficiency improvements (Shi et al., 2017).

\section{Organic loading rate $(O L R)$}

Organic loading rate (OLR) can be defined as the quantity of organic matter fed per unit volume of reactor per unit of time. This parameter plays a significant role in the AD process that serves to evaluate the performance of a reactor (Panigrahi and Dubey, 2019). The OLR values are usually associated with the HRT. If the concentration of the organic matter in the substrate is relatively constant, high OLR will be attained from short HRT. Instead, the OLR will vary at the same HRT if there are variations in the concentration of organic matter in the substrate. Generally, OLR of liquid substrates or slurry refers to organic matter expressed as $\mathrm{kg} \mathrm{COD} / \mathrm{m}^{3}$.day, while the OLR of solid feedstock refers to volatile solids denoted as $\mathrm{kg} \mathrm{VS} / \mathrm{m}^{3}$.day. OLR can be computed by using Equation 2.

$$
\operatorname{OLR}\left(\mathrm{kg} \mathrm{COD} / \mathrm{m}^{3} \cdot \text { day }\right)=\frac{Q \times S_{O}}{V}
$$

where $\mathrm{Q}$ denotes the flow rate $\left(\mathrm{m}^{3} /\right.$ day), $\mathrm{S}_{\mathrm{o}}$ denotes COD or VS concentration $(\mathrm{kg}$ $\mathrm{COD} / \mathrm{m}^{3}$ or $\left.\mathrm{kg} \mathrm{VS} / \mathrm{m}^{3}\right)$, and $\mathrm{V}$ denotes the working volume $\left(\mathrm{m}^{3}\right)$. 
The overloading system (high OLR) tends to result in the accumulation of inhibiting substances such as VFAs which will cause low biogas production and thereby causing a process termination or reactor failure. Meanwhile, reactors operating on low OLR are uneconomical because they are not fully utilized (Forgacs, 2012). Optimum OLR to dispersed growth digesters have been reported to be $1-4 \mathrm{~kg} \mathrm{VS} / \mathrm{m}^{3}$.day and $1-6 \mathrm{~kg}$ $\mathrm{COD} / \mathrm{m}^{3}$.day, $1-15 \mathrm{kgCOD} / \mathrm{m}^{3}$.day for attached growth digesters, and $5-30 \mathrm{~kg}$ $\mathrm{COD} / \mathrm{m}^{3}$.day for anaerobic filters and upflow sludge blanket digesters, respectively (Polprasert, 2007). In a biological system, OLR can be added to a degree of starvation of microorganisms where too low OLR leads to starvation, whereas high OLR leads to intoxication (subjected to fast microbial growth). The system will fail if it is not prepared because high OLR will require more bacterial to decompose the organic material found in the reactor. Acidogenic bacteria, which act early in the degradation process and multiply rapidly if given sufficient substrates, will reproduce and be able to generate acids quickly. This is one of the issues of OLR if it is not monitored since the beginning of the $\mathrm{AD}$ process. On the other hand, methanogenic bacteria that take a longer time to escalate their population will not be able to utilize acid at the same rate. As a result, the $\mathrm{pH}$ of the system will drop and this will kill more methanogenic bacteria, stop the digestion process and ultimately lead to reactor failure. Low biogas production is an indication that the system has experienced a drop in $\mathrm{pH}$ (Charalambous and Vyrides, 2021).

The OLR ranges from 1.2 to $12 \mathrm{~kg} \mathrm{VS} / \mathrm{m}^{3} /$ day or $2.2-33.7 \mathrm{kG} \mathrm{COD} / \mathrm{m}^{3} /$ day in organic digestion (Qiao et al., 2013; Guo et al., 2014). Nonetheless, the OLR behavior is influenced by substrate features, temperature conditions, and the HRT of the AD operation (Zamri et al., 2021). According to Panigrahi and Dubey (2019), many anaerobic digesters treating actual OFMSW operated at an OLR of $4.4-22 \mathrm{kgVS} / \mathrm{m}^{3} /$ day. There are several examples of studies involving the influence of OLR on biogas production during the anaerobic digestion of food waste. Nagao et al. (2012) found that as OLR climbed to $3.7,5.5,7.4$, and $9.2 \mathrm{kgVS} / \mathrm{m}^{3} /$ day, the volumetric biogas production rate has risen to roughly $2.7,4.2,5.8$, and $6.6 \mathrm{~L} / \mathrm{L} /$ day, respectively, and remained constant. The volumetric gas production rate fell below the gas production rate at OLR of $7.4 \mathrm{kgVS} / \mathrm{m}^{3} /$ day at the greatest OLR (12.9 $\mathrm{kgVS} / \mathrm{m}^{3} /$ day). Tampio et al. (2014) investigated autoclaved and untreated food waste and discovered that the maximum methane yield was produced for untreated food waste at an organic loading rate of $3 \mathrm{kgVS} / \mathrm{m}^{3} /$ day and for autoclaved food waste at a rate of $4 \mathrm{kgVS} / \mathrm{m}^{3} / \mathrm{day}$. The experiment was carried out at 2, 3, 4, and $6 \mathrm{kgVS} / \mathrm{m}^{3} /$ day. Agyeman and Tao (2014) co-digested food waste with dairy manure anaerobically at various OLRs and found that when OLR was increased from 1 to $2 \mathrm{gVS} / \mathrm{L} /$ day, biogas generation rate rose by 101-116\%, but only by $25-38 \%$ when OLR was increased from 2 to $3 \mathrm{gVS} / \mathrm{L} /$ day. In the digesters using fine and medium-sized food waste, specific methane yield reached an OLR of $2 \mathrm{gVS} / \mathrm{L} / \mathrm{day}$. In an experiment conducted by Dhar et al. (2016), 3 distinct OLRs were introduced into a lab-scale batch anaerobic digester processing OFMSW. At OLRs of 5.1, 10.4, and $15.2 \mathrm{~g} / \mathrm{L}$ COD, methane yields of $84.3,101.0$, and $168.4 \mathrm{mg} / \mathrm{gVS}_{\text {removed }}$ were recorded; the optimum OLR was discovered to be $15.2 \mathrm{~g} / \mathrm{L}$ COD for a HRT of 27 days and temperature of $38{ }^{\circ} \mathrm{C}$. Furthermore, OLR affects bacterial populations. Firmicutes are the most common bacteria at low OLR, while Gammaproteobacteria, Actinobacteria, Bacteroidetes, and Deferribacteria have been found at high OLR (Mao et al., 2015). 


\section{Anaerobic digestion of food waste}

As reported by the Food and Agriculture Organization of the United Nation in 2011, about one-third of all food produced for human consumption is wasted as much as 1.3 billion tonnes per year (Kondusamy and Kalamdhad, 2014). Of this amount, the rest of the food produced will be distributed equally between industrialized countries and developing countries. Approximately, $40 \%$ of $\mathrm{FW}$ is produced at retail and consumer levels of consumption in industrialized countries (Kondusamy and Kalamdhad, 2014). Some amount of energy can be recovered when FW is anaerobically digested. This method has a great potential to generate $367 \mathrm{~m}^{3}$ of biogas per dry tone of $\mathrm{FW}$ at about $65 \%$ of $\mathrm{CH}_{4}$ with an energy content of $6.025 \times 10^{-9} \mathrm{TWh} / \mathrm{m}^{3}$ (Kondusamy and Kalamdhad, 2014). Sen et al. (2016) agree that the selection of FW as a feedstock to run the $\mathrm{AD}$ process is a well-established process for the production of sustainable energy. The method is capable to produce carrier materials for biofertilizers (Kuruti et al., 2017), producing restricted environmental tracks (Capson-Tojo et al., 2016), and has a great prospective for energy recovery (Zhang et al., 2014; Zamanzadeh et al., 2016; Kuruti et al., 2017). Therefore, AD has been selected as one of the alternative methods that are environmentally friendly to treat the FW generated daily.

\section{The composition and characteristics of FW}

The results from the previous studies conducted worldwide by several researchers found that the composition of FW generated greatly influences the physicochemical characteristics of the FW. According to Fisgativa et al. (2016a), the value of moisture content, volatile solid fraction, and $\mathrm{pH}$ that are commonly reported worldwide are $74-90 \%, 85 \pm 5 \%$, and $5.1 \pm 0.7$, respectively, are the general characteristics of FW. The characteristics of FW which include moisture content (MC), total solids (TS), volatile solids (VS), VS/TS ratio, $\mathrm{pH}$, and $\mathrm{C}$ : $\mathrm{N}$ are summarized in Table 1. Previous studies conducted in the countries in Southeast Asian continent (Malaysia and Thailand) on FW have shown that the value of moisture content varies from 70-98\% (Ibrahim et al., 2010; Cheerawit et al., 2012; Tanimu et al., 2014). Since it has a relatively high moisture content, thus the FW contained sufficient moisture for AD. Moreover, Zhang et al. (2011, 2015, 2017, 2018, 2020), Tanimu et al. (2014), Nguyen et al. (2017), Hegde and Trabold (2019), and Chuenchart et al. (2020) found that the TS of FW sample obtained in their characterization work was in the range between 15-33\%. Meanwhile, the VS recorded was between 13-31\% in the FW sample tested. High VS indicates that the FW is rich in organic solid content which can be converted to biogas during the anaerobic digestion process. The volatile fraction of total solids of the FW (VS/TS ratio) was greater than 0.90, indicating that the FW contained more digestible organic matters which favours anaerobic conversion (Zhang et al., 2011). In anaerobic digestion of $\mathrm{FW}$, the $\mathrm{pH}$ value of the feedstock or substrate is considered a pivotal factor as the methanogenic bacteria are very sensitive to acidic conditions. An acidic environment may impede methane production and retard the growth of bacteria. Table 1 shows that the $\mathrm{pH}$ value of the $\mathrm{FW}$ produced is within the acidic $\mathrm{pH}$ range between 4.06-6.50 (Ibrahim et al., 2010; Zhang et al., 2011, 2015, 2017, 2018, 2020; Cheerawit et al., 2012; Tanimu et al., 2014; Nguyen et al., 2017; Hegde and Trabold, 2019; Chuenchart et al., 2020). In the anaerobic digestion process, constant $\mathrm{pH}$ is important in the start-up stage because the fresh $\mathrm{FW}$ to be fed into the digester has to go through the hydrolysis and acidogenesis stage before methane formation (methanogenesis stage), which will lower the $\mathrm{pH}$. To maintain the value of $\mathrm{pH}$ 
in equilibrium, a buffer such as sodium hydroxide, calcium carbonate or lime, has to be added into the digester. As shown in Table 1, FW is reported to have a $\mathrm{C}: \mathrm{N}$ ratio of 13.2-28.2 (Ibrahim et al., 2010; Zhang et al., 2011, 2015, 2017, 2020; Cheerawit et al., 2012; Tanimu et al., 2014; Nguyen et al., 2017; Hegde and Trabold, 2019; Chuenchart et al., 2020). The optimum $\mathrm{C}: \mathrm{N}$ ratio is 20-30:1, which is a suitable range used in the AD process as reported in many pieces of literature (Esposito et al., 2012). In the AD process, carbon is generally used 20-35 times faster than nitrogen by the bacteria. Thus, at optimum C: $\mathrm{N}$ ratio, the digester is anticipated to function at an optimum level to produce methane. Nitrogen is transformed to ammonium at a faster rate than can be assimilated by methanogenic bacteria at a minimum $\mathrm{C}$ : $\mathrm{N}$ ratio. Meanwhile, a high $\mathrm{C}: \mathrm{N}$ ratio will inhibit methane production due to the increase in acid formation in the digester.

Table 1. The characteristics of $F W$ as reported in the literatures

\begin{tabular}{c|c|c|c|c|c|c|c|c|c|c|c}
\hline & $\begin{array}{c}\text { Ibrahim } \\
\text { et al. } \\
(2010)\end{array}$ & $\begin{array}{c}\text { Zhang } \\
\text { et al. } \\
(2011)\end{array}$ & $\begin{array}{c}\text { Cheerawit } \\
\text { et al. } \\
(2012)\end{array}$ & $\begin{array}{c}\text { Tanimu } \\
\text { et al. } \\
(2014)\end{array}$ & $\begin{array}{c}\text { Zhang } \\
\text { et al. } \\
(2015)\end{array}$ & $\begin{array}{c}\text { Nguyen } \\
\text { et al. } \\
(2017)\end{array}$ & $\begin{array}{c}\text { Zhang } \\
\text { et al. } \\
(2017)\end{array}$ & $\begin{array}{c}\text { Zhang } \\
\text { et al. } \\
(2018)\end{array}$ & $\begin{array}{c}\text { Hedge } \\
\text { and } \\
\text { Trabold } \\
(2019)\end{array}$ & $\begin{array}{c}\text { Chuenchart } \\
\text { et al. } \\
(2020)\end{array}$ & $\begin{array}{c}\text { Zhang } \\
\text { et al. } \\
(2020)\end{array}$ \\
\hline $\begin{array}{c}\text { Moisture } \\
(\%)\end{array}$ & $70.88-$ & - & 72.31 & 97.43 & - & - & - & - & - & 85.11 & - \\
TS (\%) & - & 18.1 & - & 29.57 & 18.9 & 23.02 & 22.1 & 32.70 & 23.8 & 14.89 & 30.57 \\
VS (\%) & - & - & - & - & 17.5 & 20.55 & 20.4 & 30.99 & 22.9 & 13.89 & 29.10 \\
VS/TS & - & 0.94 & - & - & 0.93 & 0.92 & 0.92 & 0.95 & 0.91 & 0.93 & 0.95 \\
pH & $4.59-$ & 6.5 & 5.5 & 4.25 & 5.2 & 4.91 & 5.92 & - & 4.2 & 4.06 & - \\
C:N & - & 13.2 & 20.24 & 16.5 & 21.3 & $14.58-$ & 22.0 & $16.46-$ & 15.8 & 21.20 & 16.07 \\
\hline
\end{tabular}

There are various types of macronutrients and micronutrients $(\mathrm{Ni}, \mathrm{Zn}, \mathrm{Cu}, \mathrm{Pb}, \mathrm{Fe}, \mathrm{Mn}$, $\mathrm{Cd}, \mathrm{Al}, \mathrm{M}, \mathrm{P}$, and $\mathrm{K}$ ) present in the $\mathrm{FW}$ with varying concentrations. These nutrients are required by methanogenic bacteria for robust growth which plays an important role in the production of methane gas. To ensure proper bacterial metabolism and a stable AD process, these nutrients must be present in the feedstock in correct ratios and concentrations. According to Zhang et al. (2013b) and Fisgativa et al. (2016a), the characteristics of the feedstock or substrate will greatly affect the performances of the AD process. The basic features such as high carbohydrate content, extensive obtainability, and extremely decomposable organic fractions causing FW to be a very attractive source for AD substrates as well as economical for energy production.

\section{The implementation of batch or continuous method in the AD of FW}

There are two methods or systems to be described in this section, namely the batch and continuous systems. In a batch system, the feedstock will be fed into the digester and completed until the methane gas production ceases. There are several advantages of the batch system which include minimum operating costs, shorter digestion time and less complicated technical problems to be solved. Meanwhile, in the continuous system, the feedstock will be fed continuously into the digester until the steady-state condition is achieved with a constant methane yield. Compared to a batch system, continuous reactors are capable to maintain and allow the microorganisms to adapt to the system and thus 
avoiding lag time accompanied by the growth of microorganisms. However, the methane yield generated from the anaerobic conversion of organic feedstock in the continuous digester is highly dependent on the OLR and HRT.

In the batch method, Biochemical Methane Potential (BMP) test is a popular method that is often used to determine the feasibility of a substrate or feedstock in the AD process. In this BMP test, the organic materials that have been mixed with anaerobic bacteria will be incubated in the incubator under controlled conditions (e.g. temperature, mixing), and monitoring is performed on the production of methane gas. A comprehensive protocol for BMP determination has been suggested as the BMP for organic matter is extremely vital in the design, fitting, and conducting of an anaerobic reactor (Holliger et al., 2016).

Table 2 summarizes the generation of methane yield from batch anaerobic digestion of FW as reported in the literatures. Several researchers have reported that the BMP value recorded was between $400-530 \mathrm{~L} \mathrm{CH}_{4} / \mathrm{kgVS}_{\text {added }}$ when the AD process of $\mathrm{FW}$ was conducted at mesophilic temperature $\left(35-37{ }^{\circ} \mathrm{C}\right.$ ) (Izumi et al., 2010; Lu et al., 2012; Browne and Murphy, 2013; Facchin et al., 2013; Zhang et al., 2013a; Kawai et al., 2014; Ariunbaatar et al., 2014). Meanwhile, Nathao et al. (2013) and Yang et al. (2015) reported that a relatively low methane yield between $90-180 \mathrm{~L} \mathrm{CH}_{4} / \mathrm{kg} \mathrm{VS}_{\text {added }}$ was recorded when the batch $\mathrm{AD}$ process was performed at both temperatures. Low methane yield is usually associated with the acidification process that occurs during digestion.

The substrate to inoculum ratio (S/I) is a significant aspect influencing the performance of batch reactors. In order to prevent the accumulation of VFAs in inoculum particles beyond their assimilative methanogenic ability, batch reactors play a significant role. According to Kawai et al. (2014), to overcome the irreversible acidification during the start-up stage, the amount of inoculum fed into the digester has been increased to prevent the accumulation of VFAs. Based on previous studies, it is found that acidification can be prevented when the AD process is conducted at $\mathrm{S} / \mathrm{I}$ ratio below 1.0. Table 2 shows that the values of methane yield between 417-529 $\mathrm{L} \mathrm{CH}_{4} / \mathrm{kg} \mathrm{VS}$ added can be achieved from a single mesophilic batch-test performed using the $\mathrm{S} / \mathrm{I}$ ratio of $\leq 0.5$ (Browne and Murphy, 2013; Facchin et al., 2013; Kawai et al., 2014; Ariunbaatar et al., 2015a). This indicates that the stability of the process has been achieved in the AD process. Nathao et al. (2013) has conducted the AD process on synthetic FW and found that methane yield less than $100 \mathrm{~L} \mathrm{CH}_{4} / \mathrm{kg} \mathrm{VS}$ added was obtained when the high S/I ratio (greater than 1.0) was used and the AD process was performed within a shorter time (100 hours). Instead, Lu et al. (2012) obtained methane yield exceeding $400 \mathrm{~L} \mathrm{CH}_{4} / \mathrm{kg} \mathrm{VS}$ added although using a S/I ratio $\geq 1.0$ (18.9). This may be due to the application of double-stage batch reactors that can separate acidogenic and methanogenic phases and a longer digestion period (55 days).

The production of methane yield in the batch AD system is also influenced by other factors such as the impact of process temperature, addition of micronutrients or trace elements, and inoculum acclimatization. The effect of temperature (mesophilic or thermophilic) on the batch AD system plays a significant role in the production of methane. However, only a couple of studies, such as those carried out by Algapani et al. (2017), Jiang et al. (2018) and Yang et al. (2015) have concentrated on thermophilic AD. High risk of ammonia inhibition and a greater degree of imbalance are two important things that need to be considered in the implementation of thermophilic AD. At thermophilic temperature, Algapani et al. (2017) and Jiang et al. (2018) obtained higher methane yields between 531-591 $\mathrm{L} \mathrm{CH}_{4} / \mathrm{kgVS}_{\text {added, }}$, but a lower methane yield value (178 $\mathrm{L} \mathrm{CH}_{4} / \mathrm{kgVS}_{\text {added }}$ ) was achieved by Yang et al. (2015). It is due to the $\mathrm{S} / \mathrm{I}$ ratio $>1.0$ used and the difference in the characteristics of the FW based on the source of the FW. 
Table 2. Methane yield from batch anaerobic digestion of $F W$

\begin{tabular}{|c|c|c|c|c|}
\hline Substrate & $\begin{array}{c}\text { Anaerobic digestion } \\
\text { conditions }\end{array}$ & $\mathbf{S} / \mathbf{I}$ & $\begin{array}{c}\text { Methane yield } \\
\text { L CH4 }_{4} / \mathbf{k g ~ V S} \text { added }\end{array}$ & References \\
\hline $\begin{array}{l}\text { Disposer ground } \\
\text { standard FW }\end{array}$ & $\begin{array}{c}\text { Volume }=1 \mathrm{~L} \\
\text { Temperature }=\text { Mesophilic } \\
\text { Digestion period = } 16 \text { days }\end{array}$ & N.R & 417 & Izumi et al. (2010) \\
\hline Standard FW & $\begin{array}{c}\text { Volume }=2 \mathrm{~L} \\
\text { Temperature }=\text { Mesophilic } \\
\text { Digestion period }=45 \text { days }\end{array}$ & 0.33 & 435 & Kawai et.al (2014) \\
\hline Canteen FW & $\begin{array}{c}\text { Volume }=1 \mathrm{~L} \\
\text { Temperature }=\text { Mesophilic } \\
\text { Digestion period }=28 \text { days }\end{array}$ & $8 \mathrm{~g} \mathrm{VS} / \mathrm{L}$ & 410 & Zhang et al. (2013a) \\
\hline Synthetic FW & $\begin{array}{c}\text { Volume }=1 \mathrm{~L} \\
\text { Temperature }=\text { Mesophilic } \\
\text { Digestion period }=25 \text { days }\end{array}$ & 0.5 & $469 \pm 6.8$ & $\begin{array}{l}\text { Ariunbaatar et al. } \\
\qquad(2015 a)\end{array}$ \\
\hline Canteen FW & $\begin{array}{c}\text { Volume }=0.5 \mathrm{~L} \\
\text { Temperature }=\text { Thermophilic } \\
\text { Digestion period }=29 \text { days }\end{array}$ & $\begin{array}{l}20.12 \mathrm{~g} \\
\text { VS/L }\end{array}$ & $591 \pm 30$ & Jiang et al. (2018) \\
\hline Synthetic FW & $\begin{array}{c}\text { Volume }=0.5 \text { L each (Double } \\
\text { stage) } \\
\text { Temperature }=\text { Mesophilic } \\
\text { Digestion period }=100 \text { hours }\end{array}$ & 7.5 & 94 & Nathao et al. (2013) \\
\hline Canteen FW & $\begin{array}{c}\text { Volume }=0.5 \mathrm{~L} \\
\text { Temperature }=\text { Thermophilic } \\
\text { Digestion period }=28 \text { days }\end{array}$ & 1.5 & 178 & Yang et al. (2015) \\
\hline Canteen FW & $\begin{array}{c}\text { Volume }=0.12 \mathrm{~L} \\
\text { Temperature }=\text { Thermophilic } \\
\text { Digestion period }=55 \text { days }\end{array}$ & N.R & 531 & $\begin{array}{l}\text { Algapani et al. } \\
\quad(2017)\end{array}$ \\
\hline $\begin{array}{l}\text { Vegetable waste } \\
\text { from the } \\
\text { supermarket }\end{array}$ & $\begin{array}{l}\text { Volume }=1 \mathrm{~L} \text { (Double stage) } \\
\text { Temperature }=\text { Mesophilic } \\
\text { Digestion period }=55 \text { days }\end{array}$ & 18.9 & 445 & Lu et al. (2012) \\
\hline Canteen FW & $\begin{array}{c}\text { Volume }=0.5 \mathrm{~L} \\
\text { Temperature }=\text { Mesophilic } \\
\text { Digestion period }=25 \text { days }\end{array}$ & 0.33 & 529 & $\begin{array}{l}\text { Browne and Murphy } \\
\qquad(2013)\end{array}$ \\
\hline $\begin{array}{c}\text { Source segregated } \\
\text { FW }\end{array}$ & $\begin{array}{c}\text { Volume }=\text { N.R } \\
\text { Temperature }=\text { Mesophilic } \\
\text { Digestion period }=40 \text { days }\end{array}$ & $0.3-0.4$ & $\begin{array}{c}434 \pm 40 \text { (inoculum } \\
\mathrm{A} \text { ) } \\
338 \pm 30 \\
\text { (inoculum B) }\end{array}$ & Facchin et al. (2013) \\
\hline
\end{tabular}

Batch anaerobic digestion was carried out using 0.12-2.0 L screw cap bottles and glass reactors, N.R= not reported

Several studies on the addition of micronutrients were conducted during AD of FW. Micronutrients such as $\mathrm{Na}, \mathrm{Ni}, \mathrm{Co}, \mathrm{Fe}, \mathrm{Zn}, \mathrm{Mg}, \mathrm{Ca}, \mathrm{K}, \mathrm{W}$, and Mo help the methanogens to grow. High methane yields (45-65\%) have been achieved when micronutrients such as $\mathrm{Co}, \mathrm{Mo}, \mathrm{Ni}, \mathrm{Se}$, and $\mathrm{W}$ were added to the $\mathrm{FW}$ during the digestion process (Facchin et al., 2013). The addition of Se and Mo with a concentration of $10 \mathrm{mg} / \mathrm{kg}$ and 3-12 mg/kg dry matter, respectively, will enhance the production of methane up to $30-40 \%$. The study 
on the effects of the use of an acclimatized inoculum in the BMP test to promote the production of methane was conducted by some previous researchers. Browne and Murphy (2013) emphasize that for precise BMP evaluation, inoculums must be obtained from the $\mathrm{AD}$ process that has achieved stability and is acclimatized to their substrate. However, Holliger et al. (2016) argue that the inoculum to be used in the AD process does not need to be acclimatized first with the feedstock to be tested. This is based on the comparisons of the latest methodologies used in different laboratories. Facchin et al. (2013) also studied the effect of inoculum source and found that high methane yield $\left(434 \mathrm{~L} \mathrm{CH}_{4} / \mathrm{kg}\right.$ $\mathrm{VS}_{\text {added }}$ ) was produced in the AD process when the inoculum from anaerobic digester codigesting FW and waste activated sludge was used rather than consuming the inoculum obtained from anaerobic digester handling only $\mathrm{FW}\left(338 \mathrm{~L} \mathrm{CH}_{4} / \mathrm{kg} \mathrm{VS}_{\text {added }}\right)$.

Two limits influence the effectiveness of methane gas production from a semicontinuous digester that processes $\mathrm{FW}$, i.e solubilization of organic matters and acidogenesis stage. According to Capson-Tojo et al. (2016), to ensure the success of biogas production, two critical factors should be given special attention which is microbial communities and the quality of inoculum to be applied in the digester start-up process. Long acclimatization duration and operational changes that occur gradually in the semi-continuous digester are caused by slower growth of methanogens than acidogens. The semi-continuous test requires a longer period. The digestion process is considered to have reached stability when parameters such as $\mathrm{pH}$, VS content, and specific methane production recorded an average value of around 10\% consistently for a minimum duration of one HRT.

The performance for a single and two-stage for the semi-continuous AD system that has been reported by some previous researchers is shown in Table 3. In the semicontinuous AD system, parameters such as OLR and HRT greatly affect the stability of the digester and methane gas production. It can be inferred from Table 3 that equilibrium has been achieved in the AD of FW when OLR is less than $4.5 \mathrm{gVS} / \mathrm{L}$.day and HRT range between 16-40 days. The range of methane yield obtained is between $316-544 \mathrm{LCH}_{4} / \mathrm{kg}$ $\mathrm{VS}_{\text {added }}$ (Shen et al., 2013; Ventura et al., 2014; Grimberg et al., 2015; Zhang et al., 2015; Voelklein et al., 2016; Zamanzadeh et al., 2016). According to Ariunbaatar et al. (2015a), the AD can operate at high OLR and subsequently produces high methane yield without decreasing the $\mathrm{pH}$ when the $\mathrm{AD}$ system has high buffering capacity due to the production of total ammoniacal nitrogen (TAN). The literature has indicated a wide range of inhibitory (TAN) concentrations (1700-14000 mg/L). Unacclimated microorganisms are hazardous at TAN concentrations of 1700-2000 mg/L, whereas acclimated methanogens can be inhibited at concentrations of 12,000-14,000 mg/L (Ariunbaatar et al., 2015a). However, this depends on the operating parameters, source of inoculum, and feedstock applied. The addition of micronutrients in a small quantity in the FW plays a significant role in the AD process. According to Yirong et al. (2015), the addition of micronutrients such as selenium (Se) into the digester can restore the digester that experiences propionic acid accumulation due to the increase in the concentrations of ammonia. The addition of cobalt is required in the digester which operates at high OLR.

The two-stage AD system separates between acidogenesis and methanogenesis phases that optimize the reactor condition for different microbes performing their functions. In the acidogenesis (first stage), lower $\mathrm{pH}$ and shorter HRT (2-3 days) lead to the washout of acidogenic bacteria. Meanwhile, methanogenesis (second stage) which occurs in the $\mathrm{pH}$ range of 6-8 and HRT of 20-30 days provides a suitable environment for the development of slow-growing methanogens. Grimberg et al. (2015) have made 
comparisons in methane yields between single-stage and two-stage anaerobic digesters processing kitchen waste with a capacity of $5 \mathrm{~m}^{3}$ in mesophilic conditions. Two-stage digesters produced higher methane yield (446 $\mathrm{LCH}_{4} / \mathrm{kg} \mathrm{VS}_{\text {added }}$ ) compared to single-stage digester (380 $\mathrm{LCH}_{4} / \mathrm{kg} \mathrm{VS}$ added). It is found that OLR used for the single-stage digester was much higher than the two-stage digester. At the same time, the fermentation reactor can maintain stability with $\mathrm{pH} 5.2$ despite operating under very low OLR $\left(0.78 \mathrm{~kg} \mathrm{COD} / \mathrm{m}^{3} \mathrm{~d}\right)$. Ventura et al. (2014) treated FW from an FW recycling company using an alternating mesophilic and thermophilic two-stage AD process involving three different temperature combinations (mesophilic: mesophilic, mesophilic: thermophilic, thermophilic: mesophilic) and found that the highest methane yield was recorded (440 $\mathrm{L} \mathrm{CH}_{4} / \mathrm{kgVS}_{\text {added}}$ ) when the $\mathrm{FW}$ was treated using a combination of mesophilic: thermophilic two-stage AD process. Due to higher temperatures in the second digester, the process was found to be less stable than the first digester. The use of higher OLR and the combination of thermophilic: thermophilic two-stage AD by Micolucci et al. (2014) produced higher methane yields of $476 \mathrm{~L} \mathrm{CH}_{4} / \mathrm{kg} \mathrm{VS}$ added. By optimizing OLRs and HRTs using methanogenic sludge recirculation, this combination will prevent inhibition from happening in the digesters. Additionally, Chu et al. (2012) used the same combination of two-stage AD to treat the same waste without sludge recirculation and thereby achieved low methane yield (364 $\mathrm{L} \mathrm{CH}_{4} / \mathrm{kg} \mathrm{VS}_{\text {added}}$ ) with low TS content in the feedstock. Shen et al. (2013) conducted a study on the FW mixed with vegetable and fruit waste using a twostage anaerobic digester. They found that this digester was able to produce a higher methane yield (546 $\mathrm{L} \mathrm{CH}_{4} / \mathrm{kg} \mathrm{VS}_{\text {added}}$ ) because it is less susceptible to overloading systems due to the increase in methanogenic activity.

During the AD process in a single-stage digester, all four AD stages in the biochemical pathway including hydrolysis, acidogenesis, acetogenesis, and methanogenesis occur in the same digester in which polymeric organic compounds converted to $\mathrm{CH}_{4}, \mathrm{H}_{2} \mathrm{~S}, \mathrm{NH}_{3}$, and $\mathrm{CO}_{2}$ are also taken place in the same digester (Kondusamy and Kalamdhad, 2014). The use of a single-stage digester to treat complex FW has been proposed by Shen et al. (2013), Zhang et al. (2014), and Tran (2017). Up to 38\% more methane is obtained when the AD process is performed in a single-stage digester than a two-stage digester (Nagao et al., 2012). The use of a single-stage digester in AD of FW also exhibits an increase in methane yield as shown in Table 3. Tampio et al. (2014) reported that about $483 \pm 13 \mathrm{LCH}_{4} / \mathrm{kg} \mathrm{VS}_{\text {added }}$ of methane yield was obtained when treating source segregated domestic FW using $1 \mathrm{~L}$ single-stage digester at the mesophilic condition with an OLR of $3 \mathrm{~g} \mathrm{VS} / \mathrm{L} . \mathrm{d}$, where the VS removal obtained was $77.7 \%$. A comparison has been made by Zamanzadeh et al. (2016) in methane yield produced by two $10 \mathrm{~L}$ single-stage digesters operating at two different conditions, i.e. mesophilic and thermophilic, but at the same OLR and HRT ( $3 \mathrm{gVS} / \mathrm{L}$.day, 20 days) with digestate recirculation. The resulting methane yield was higher $\left(480 \pm 33 \mathrm{LCH}_{4} / \mathrm{kg} \mathrm{VS}\right.$ added $)$ in the mesophilic single-stage digester than thermophilic single-stage digester ( $448 \pm 44 \mathrm{LCH}_{4} / \mathrm{kg} \mathrm{VS}$ added). It also shows that the recirculation of digestate worked very well under mesophilic conditions. Zhang et al. (2015a) have investigated the effect of micronutrients on the anaerobic digestion of campus restaurant FW in a single-stage digester operating at OLRs ranging from 1.0 to $5.5 \mathrm{~g} \mathrm{VS} / \mathrm{L} . \mathrm{d}$ in mesophilic conditions. A high methane yield (465.4 $\mathrm{L} \mathrm{CH}_{4} / \mathrm{kgVS}_{\text {added }}$ ) was obtained. In the digester containing micronutrients, there was no substantial buildup of VFA. These data suggest that introducing micronutrients to the $\mathrm{AD}$ of $\mathrm{FW}$ has a significant influence on its stability. 
Table 3. The performance of semi-continuous AD involving single and double stage digesters

\begin{tabular}{|c|c|c|c|c|c|c|c|}
\hline $\begin{array}{c}\text { Type of } \\
\text { FW/source }\end{array}$ & $\begin{array}{c}\text { Single/double } \\
\text { stage } \\
\text { digesters/type } \\
\text { of reactor } \\
\text { (volume) } \\
\end{array}$ & $\begin{array}{c}\text { Process } \\
\text { temperature } \\
/ \\
\text { condition }\end{array}$ & $\begin{array}{c}\text { HRT } \\
\text { (days) }\end{array}$ & $\begin{array}{c}\text { Digestion } \\
\text { period }\end{array}$ & $\begin{array}{c}\text { OLR } \\
\text { (g VS/L.d; } \\
\text { kg } \\
\text { VS } / \mathbf{m}^{3} \text {.day) }\end{array}$ & $\begin{array}{l}\text { Methane } \\
\text { yield } \\
\text { (LCH4/kg } \\
\left.\text { VS }_{\text {added }}\right)\end{array}$ & References \\
\hline $\begin{array}{c}\mathrm{FW}+\text { fruit and } \\
\text { vegetable } \\
\text { waste }\end{array}$ & $\begin{array}{l}\text { Single (8L) } \\
\text { Double } \\
\text { (5L: 8L) } \\
\text { CSTR }\end{array}$ & $\begin{array}{l}\text { Mesophilic } \\
\text { Mesophilic: } \\
\text { Mesophilic }\end{array}$ & $\begin{array}{c}30 \text { days } \\
10 \text { days: } 10 \\
\text { days }\end{array} \mid$ & $\begin{array}{l}210 \text { days } \\
210 \text { days }\end{array}$ & \begin{tabular}{|c|}
$1-3.5$ \\
First stage: \\
$2.0-10$ \\
Second stage \\
$: 1.0-5.0$ \\
\end{tabular} & $\begin{array}{l}328-544 \\
198-546\end{array}$ & $\begin{array}{l}\text { Shen et al. } \\
\text { (2013) }\end{array}$ \\
\hline $\begin{array}{l}\text { Local waste } \\
\text { management } \\
\text { company }\end{array}$ & $\begin{array}{c}\text { Double } \\
(5 \mathrm{~L}: 5 \mathrm{~L}) \\
\text { Single }(5 \mathrm{~L}) \\
\text { CSTR } \\
\end{array}$ & $\begin{array}{l}\text { Mesophilic: } \\
\text { Mesophilic } \\
\text { Mesophilic }\end{array}$ & $\begin{array}{c}4 \text { days: } 12 \\
\text { days } \\
16 \text { days }\end{array}$ & $\begin{array}{l}\text { N.R } \\
\text { N.R }\end{array}$ & $\begin{array}{c}15: 5 \\
4\end{array}$ & $\begin{array}{l}389.2 \pm 31.8 \\
316.4 \pm 17.9\end{array}$ & $\begin{array}{l}\text { Voelklein et } \\
\text { al. (2016) }\end{array}$ \\
\hline $\begin{array}{c}\text { Source } \\
\text { segregated FW } \\
\text { (with } \\
\text { micronutrients) } \\
\end{array}$ & $\begin{array}{l}\text { Single (5L) } \\
\text { CSTR }\end{array}$ & Thermophilic & N.R & 50 days & 2 & 400 & $\begin{array}{c}\text { Yirong et al. } \\
(2015)\end{array}$ \\
\hline $\begin{array}{l}\text { Pasteurized } \\
\text { FW }\end{array}$ & $\begin{array}{l}\text { Single }(10 \mathrm{~L}) \\
\text { Single }(10 \mathrm{~L}) \\
\text { CSTR }\end{array}$ & $\begin{array}{l}\text { Mesophilic } \\
\text { Thermophilic }\end{array}$ & $\begin{array}{l}20 \text { days } \\
20 \text { days }\end{array}$ & $\begin{array}{l}152 \text { days } \\
152 \text { days }\end{array}$ & $\begin{array}{l}3 \\
3\end{array}$ & $\begin{array}{l}480 \pm 33 \\
448 \pm 44\end{array}$ & $\begin{array}{l}\text { Zamanzadeh } \\
\text { et al. (2016) }\end{array}$ \\
\hline $\begin{array}{l}\text { Campus } \\
\text { restaurant } \\
\text { (with TEs) }\end{array}$ & $\begin{array}{c}\text { Single }(6 \mathrm{~L}) \\
\text { Semi continuous } \\
\text { fed digester }\end{array}$ & Mesophilic & 40 days & - & 4.5 & 465.4 & $\begin{array}{l}\text { Zhang et al. } \\
\text { (2015a) }\end{array}$ \\
\hline $\begin{array}{c}\text { Source } \\
\text { segregated } \\
\text { domestic FW }\end{array}$ & $\begin{array}{c}\text { Single }(11 \mathrm{~L}) \\
\text { SCSTR }\end{array}$ & Mesophilic & 78 days & 100 days & 3 & $483 \pm 13$ & $\begin{array}{l}\text { Tampio et } \\
\text { al. (2014) }\end{array}$ \\
\hline Kitchen & $\begin{array}{c}\text { Single }\left(5 \mathrm{~m}^{3}\right) \\
\text { Double } \\
\left(5 \mathrm{~m}^{3}: 5 \mathrm{~m}^{3}\right) \\
\text { CSTR } \\
\end{array}$ & $\begin{array}{l}\text { Mesophilic } \\
\text { Mesophilic: } \\
\text { Mesophilic }\end{array}$ & $\begin{array}{l}\text { N.R } \\
\text { N.R }\end{array}$ & $\begin{array}{l}6 \text { months } \\
400 \text { days }\end{array}$ & $\begin{array}{l}3.79 \\
0.78\end{array}$ & $\begin{array}{l}380 \\
446\end{array}$ & $\begin{array}{l}\text { Grimberg et } \\
\text { al. (2015) }\end{array}$ \\
\hline $\begin{array}{l}\text { Incoming FW } \\
\text { at the WWTP }\end{array}$ & $\begin{array}{c}\text { Double } \\
\text { (200 L : 380L) } \\
\text { CSTR }\end{array}$ & $\begin{array}{c}\text { Thermophilic } \\
\text { : } \\
\text { Thermophilic }\end{array}$ & $\begin{array}{l}3.3 \text { days : } \\
12.6 \text { days }\end{array}$ & 140 days & $18.4: 4.8$ & 476 & $\begin{array}{l}\text { Micolucci et } \\
\text { al. (2014) }\end{array}$ \\
\hline $\begin{array}{l}\text { Kitchen } \\
\text { garbage }\end{array}$ & $\begin{array}{l}\text { Double } \\
(1 \mathrm{~L}: 5 \mathrm{~L}) \\
\text { CSTR }\end{array}$ & $\begin{array}{c}\text { Thermophilic } \\
\text { : } \\
\text { Thermophilic }\end{array}$ & $\begin{array}{c}2 \text { days : } 10 \\
\text { days }\end{array}$ & 60 days & N.R & 364 & $\begin{array}{l}\text { Chu et al. } \\
\text { (2012) }\end{array}$ \\
\hline $\begin{array}{l}\text { Food waste } \\
\text { recycling } \\
\text { company }\end{array}$ & $\begin{array}{c}\text { Double } \\
(10 \mathrm{~L}: 30 \mathrm{~L}) \\
\text { Double } \\
(10 \mathrm{~L}: 30 \mathrm{~L}) \\
\text { Double } \\
(10 \mathrm{~L}: 30 \mathrm{~L}) \\
\text { CSTR } \\
\end{array}$ & $\begin{array}{l}\text { Mesophilic: } \\
\text { Mesophilic } \\
\text { Mesophilic: } \\
\text { Thermophilic } \\
\text { Thermophilic } \\
\text { : Mesophilic }\end{array}$ & $\begin{array}{c}5 \text { days: } 15 \\
\text { days } \\
5 \text { days: } 15 \\
\text { days } \\
5 \text { days: } 15 \\
\text { days }\end{array}$ & $\begin{array}{l}195 \text { days } \\
109 \text { days } \\
43 \text { days }\end{array}$ & $\begin{array}{l}3.2 \\
4.4 \\
4.0\end{array}$ & $\begin{array}{l}380 \\
440 \\
370\end{array}$ & $\begin{array}{l}\text { Ventura et } \\
\text { al. (2014) }\end{array}$ \\
\hline
\end{tabular}

\section{Methods for improving the AD of FW}

Food waste $(\mathrm{FW})$ is a complex organic material that consists of highly recalcitrant substances up to biodegradable compounds. Therefore, to enhance the performance of $\mathrm{AD}$ of FW, two main strategies can be utilized: 1) co-digestion the FW with the different 
substrate to stabilize the entire process and 2) conducting the pretreatment on the feedstock to increase the solubilization of organic matter in the AD process.

\section{a, Co-digestion of $F W$ with other substrates}

Siddique and Wahid (2018) have considered co-digestion as the instantaneous digestion of two or more substrate and co-substrate mixtures. Co-digestion of FW with organic substrates is getting more attention from researchers who have conducted researches related to the AD of FW. The ability to increase the number of major nutrients, stabilize the digestate produced, dilute toxic chemicals, balance the nutrients, and take full advantage of the synergistic effect of microorganisms to enhance biogas and methane production for an efficient AD process are all advantages of the co-digestion strategy (Nghiem et al., 2017; Chen et al., 2020). According to Mata-Alvarez et al. (2014), green waste and agricultural waste, sewage sludge and animal dungs are among the organic wastes that are often used to co-digest with the FW to increase the biogas and methane yields. Table 4 shows a summary of anaerobic digestion of FW with different cosubstrates involving green/agricultural waste, sewage sludge, and animal dungs obtained from the previous literatures.

Due to a very low cost associated with their collection, agricultural waste and green waste can be considered as the potential co-substrate to be mixed with FW besides animal dungs and sewage sludge (Chen et al., 2014). According to Gianico et al. (2013), conducting $\mathrm{AD}$ processes on agricultural waste and green waste will face various challenges. Besides having high lignin and cellulose content, these wastes are not suitable for single digestion because of several reasons such as low nutrient content, long retention time, and have a great potential to produce inhibitory compounds. The biodegradable rate of FW can be reduced when co-digesting the FW with agricultural waste or green waste to prevent the accumulation of VFAs in the digester. Yong et al. (2015) reported that an increase in methane yields from 171 to $313 \mathrm{LCH}_{4} / \mathrm{kg} \mathrm{VS}$ added were observed when the FW ratio was increased during mesophilic batch co-digestion $\left(35^{\circ} \mathrm{C}\right.$ with the initial loading of $5 \mathrm{gVS} / \mathrm{L} . \mathrm{d}$ ) with straw. Owamah and Izinyon (2015) achieved an increase in methane yields of up to $482 \mathrm{~L} \mathrm{CH}_{4} / \mathrm{kg} \mathrm{VS}$ added with the removal of approximately $74.3-80.7 \%$ of VS when co-digesting FW with maize husk (MH). Ratanatamskul and Manpetch (2016) have attempted to co-digest the $\mathrm{FW}$ with rain tree leaf using a pilot-scale single-stage $(2500 \mathrm{~L})$ and two-stage $(1000 \mathrm{~L}: 2500 \mathrm{~L})$ digesters and found that the VS removal was higher than $80 \%$, but the resulting methane yield was lower: $153 \mathrm{~L} \mathrm{CH}_{4} / \mathrm{kg} \mathrm{VS}_{\text {added }}$ (singlestage) and $283 \mathrm{~L} \mathrm{CH}_{4} / \mathrm{kg} \mathrm{VS}_{\text {added }}$ (two-stage). Jabeen et al. (2015) co-digested FW with rice husk $(\mathrm{RH})$ with $\mathrm{C}$ : $\mathrm{N}$ ratio of 28 using an $80 \mathrm{~L}$ pilot-scale plug flow reactor at $37{ }^{\circ} \mathrm{C}$. When the OLR was raised from $5 \mathrm{gVS} / \mathrm{L}$.d to $9 \mathrm{gVS} / \mathrm{L}$.d, it was found that there was a reduction in the reactor stability, VS removal efficiency (a decline from $82.4 \%$ to $35.4 \%$ ), and biogas production (from $446 \mathrm{~L}$ biogas $/ \mathrm{kg}$ VS to $215 \mathrm{~L}$ biogas $/ \mathrm{kg}$ VS). Tanimu et al. (2014) co-digested FW mixture ( $\mathrm{C}: \mathrm{N}$ ratio 17 ) with meat, fruits, and vegetable wastes to achieve a $\mathrm{C}: \mathrm{N}$ ratio of 26 and 30 . From their work, it can be seen that the increase in methane yield is $48.2 \%$ from 0.352 to $0.679 \mathrm{~L} / \mathrm{gVS}_{\text {added }}$ and at the same time recording the methane composition by $85 \%$. COD removal showed an increase from $69 \%$ to $85 \%$ at $\mathrm{C}: \mathrm{N}$ ratio of 30 . While at $\mathrm{C}: \mathrm{N}$ ratio of 26 , the increase in methane yield is $21.3 \%$ from 0.352 to $0.447 \mathrm{~L} / \mathrm{gVS}$ added and recorded $54 \%$ and $74 \%$ of VS and COD removal, respectively. Panigrahi et al. (2020) used mesophilic conditions to co-digest FW (rice, cooked vegetables, bread, meat) with pretreated YW (grass-33\% w/w; dry leaves-65\% w/w; wood chips-2\% w/w). They discovered that anaerobic co-digestion of FW with 
pretreated $\mathrm{YW}$ at $\mathrm{F} / \mathrm{M}$ ratio of 1.5 improved biogas generation to $431 \mathrm{~mL} / \mathrm{g} \mathrm{VS}_{\text {added, }}$, with VS removal of $62 \%$. Tayyab et al. (2019) have conducted anaerobic co-digestion of catering food waste (CFW) and pretreated parthenium weed (PPW) to assess the potential of these plants for biogas production. The investigation involved different mixing ratios (0: 100, 20:80, 60:40, 40:60, 80:20, and 100: 0 TS basis) using laboratory-scale bioreactors under mesophilic conditions $\left(30 \pm 1{ }^{\circ} \mathrm{C}\right)$. The results showed that in the codigestion reactor, where $60 \% \mathrm{CFW}$ and $40 \% \mathrm{PPW}$ were employed, the maximum biogas production rate $(559 \mathrm{~mL} / \mathrm{L}$.day) and accumulative biogas $(5532 \mathrm{~mL} / \mathrm{L})$ were attained.

Sewage sludge is another co-substrate for FW which is often used by researchers in studies related to anaerobic co-digestion. Sewage sludge has a low $\mathrm{C}$ : $\mathrm{N}$ ratio and organic content. These two characteristics can help to balance $\mathrm{C}: \mathrm{N}$ ratio, reduce the intermediate accumulation such as ammonia and increase the microbial activity (Liu et al., 2013). Dai et al. (2013) co-digested the FW with dewatered sludge and found that the stability has been achieved and produced high methane yield $\left(258-380 \mathrm{LCH}_{4} / \mathrm{kgVS}_{\text {added }}\right)$ with VS removal of 46-67\%. Meanwhile, Gou et al. (2014) conducted anaerobic co-digestion of FW and WAS using a mixing ratio of 33: 67 with increased temperature and increased HRT using $2 \mathrm{~L}$ CSTR. The increased process temperature up to the thermophilic condition was found to result in higher methane yields from $250 \mathrm{LCH}_{4} / \mathrm{kg}$ VS to $370 \mathrm{LCH}_{4} / \mathrm{kg}$ VS, but the VS removal decreased from $62-58 \%$. The co-digestion between FW and WAS resulted in a significant reduction in volatile solids in a single-stage and two-stage CSTR up to $48 \%$ and a significant increase in biogas yields, i.e. $960 \mathrm{~L}$ biogas/kg VS (single-stage) and 440 L biogas/kg VS (two-stage) (Zhang et al., 2013b).

The use of biochar to AD processes improves the removal of COD and lowers the lag phase of methanogenesis, resulting in increased methane generation (Kumar et al., 2021). Li et al. (2018) utilized biochar in batch tests to increase stable and efficient methane generation from thermophilic co-digestion of food waste (FW) and waste activated sludge (WAS) at F/S ratios of $0.25,0.75,1.5,2.25$, and 3 . The addition of biochar significantly reduced the lag time of methane production and enhanced the rate of methane production with increased organic loading, according to the findings. Microorganism growth and adaptation to VFA accumulation were aided by biochar's increased buffer capacity and large specific surface area.

Features such as the low $\mathrm{C}$ : $\mathrm{N}$ ratio and a wide range of macronutrients and micronutrients needed by anaerobic bacteria have resulted in the combination of animal waste with $\mathrm{FW}$ to encourage higher methane yields through the $\mathrm{AD}$ process as an excellent co-substrate. The results from the co-digestion of fine and coarse ground FW particle and dairy manure showed that the highest specific methane yield $\left(630 \mathrm{LCH}_{4} / \mathrm{kg}\right.$ $\mathrm{VS}_{\text {added }}$ ) was obtained in the fine ground $\mathrm{FW}$ while the lowest methane yield (470 $\mathrm{LCH}_{4} / \mathrm{kg} \mathrm{VS}$ added) was obtained in the coarse ground food co-digested with dairy manure (Agyeman and Tao, 2014). Wang et al. (2014) used chicken manure as a cosubstrate to study the possibility of increasing methane yield from the co-digestion of FW with chicken manure in CSTR using alternate feeding mode (FW and chicken manure were fed into the reactor alternately) at OLR $2.50 \mathrm{gVS} / \mathrm{L}$.day. A higher methane yield of $508 \mathrm{~mL} / \mathrm{gVS}$ was obtained from the co-digestion process. Zhang et al. (2012) conducted a study using a continuously stirred tank reactor (CSTR) with the capacity of $75 \mathrm{~L}$ to co-digest FW with cattle slurry (CS) with a ratio of 20:80 (FW: CS). Greater stability was achieved when operating at OLR $2 \mathrm{kgVS} / \mathrm{m}^{3}$.day with the methane yield of $220 \mathrm{~L}$ $\mathrm{CH}_{4} / \mathrm{kgVS}$ added. According to Naran et al. (2016), when mono-digestion was conducted on the FW, it produces a lot of VFAs together with substances containing ammonium, 
which impede microbial activity and digestion rate. When FW is digested at organic loadings of more than $2.5 \mathrm{~g} \mathrm{VS} / \mathrm{L} / \mathrm{d}$ and at predominantly thermophilic conditions, the $\mathrm{AD}$ process can become more extreme and even fail completely (Oladejo et al., 2020). To address this issue, FW is frequently co-digested with animal dung, lignocelluloses, and sewage sludge, which assist to dilute harmful chemicals, improve nutritional balance, and accelerate microbial activities (Zhang et al., 2014). In the production of biogas, cow dung (CD) is a significant organic feedstock (Franco et al., 2018). Due to its poor biogas output, it is frequently co-digested with other biodegradable organic feedstock in order to boost biogas yield (Ormaechea et al., 2018). According to Dhamodharan et al. (2015), although co-digested of FW with the $\mathrm{CD}$ is revealed to generate the highest methane compared to other livestock manure, Gaur and Suthar (2017) noted that the combination of a few types of animal manure in anaerobic co-digestion with FW will increase biogas production. As a result, Oladejo et al. (2020) have used automated batch anaerobic reactors to examine the production of biogas from co-digestion of FW with 2 types of animal manure namely cow dung (CD) and piggery dung (PD). The major goal of their research is to see how substrate mixing affects the overall reactor and biogas production. Although biogas was generated by mono-digesting each of the substrates, nutritional balance and gas output were severely limited. From the observation, after 30 days, the digestion of FW + CD + PD produced the maximum cumulative biogas yield of $0.67 \mathrm{~L}$. The digestion of FW + PD yielded the highest methane level of 64.6\%, while digestion of FW alone yielded the lowest $(54.0 \%)$. Overall, the four digestion regimes of cumulative biogas production can be stated in the following order: FW + CD + PD, FW $+\mathrm{PD}, \mathrm{FW}+\mathrm{CD}$, and FW only.

Apart from the utilization of agricultural waste or green waste, sewage sludge, and animal manures as co-substrate in the $\mathrm{AD}$ of $\mathrm{FW}$, researchers have carried out extensive research on other co-substrates such as fresh leachate (Zhang et al., 2015b), brown wastewater (Paudel et al., 2017) and grease trap waste (Wu et al., 2016) which can help to increase higher methane production and reactor stability. In conclusion, anaerobic codigestion has been identified as an efficient, low-cost, and adaptable method for minimizing process constraints and improving digestion and biodegradation rates, the quantity of biogas, and methane yield. There are various types of co-substrates commonly used in the anaerobic co-digestion of organic waste including the organic fraction of MSW, fat, oil, and grease (FOG), lipid-rich industrial effluent, agricultural waste (including animal manure), sewage sludge, and wood waste. Agricultural waste/green waste, sewage sludge, and animal manure are among the potential co-substrate that are often used in anaerobic co-digestion of FW. The agricultural plant residues consist of rice husks, sugar cane fiber, coconut husks and shells, groundnut shells, wheat straws, and other crop residues. Animal manures usually comprise cattle, chicken, and pig manure. HRT, OLR, operating temperature (mesophilic and thermophilic), $\mathrm{C}$ : $\mathrm{N}$ ratio, particle size, and feeding method can all affect co-digestion with different substrates. Although co-digestion can offer essential nutrients, the features and components of the substrates must be thoroughly examined to guarantee that the anaerobic co-digestion process produces good outcomes. To prevent the inhibition and optimize the production of methane gas, the mixture ratio between FW and selected co-substrate should provide positive interactions based on proper nutrient selection and moisture balance. If the selection of the combination between FW and the co-substrate is not appropriate, negative results will be achieved such as low methane yield and digester instability. 
Table 4. Anaerobic co-digestion of FW with other substrates

\begin{tabular}{|c|c|c|c|c|c|c|c|c|c|}
\hline $\begin{array}{l}\text { Types of co- } \\
\text { substrate }\end{array}$ & $\begin{array}{l}\text { Types of co- } \\
\text { digestion }\end{array}$ & $\begin{array}{l}\text { Types of } \\
\text { reactor }\end{array}$ & $\begin{array}{c}\text { Process } \\
\text { temperature/ } \\
\text { condition }\end{array}$ & HRT & OLR or $\mathrm{S} / \mathrm{I}$ & $\begin{array}{c}\text { Duration } \\
\text { (days) }\end{array}$ & $\begin{array}{c}\text { VS } \\
\text { removal } \\
(\%)\end{array}$ & $\begin{array}{c}\mathrm{CH}_{4} \text { yield } \\
\left(\mathrm{LCH}_{4} / \mathrm{kg} \mathrm{VS}\right)\end{array}$ & References \\
\hline \multirow{6}{*}{$\begin{array}{c}\text { Agricultural } \\
\text { waste / green } \\
\text { waste }\end{array}$} & $\begin{array}{c}\mathrm{FW}+\text { pretreated } \\
\text { yard waste } \\
(\mathrm{PYW})\end{array}$ & Batch & Mesophilic $\left(30^{\circ} \mathrm{C}\right)$ & NR & $\begin{array}{l}1.0 \\
1.5 \\
2.0 \\
2.5\end{array}$ & $\begin{array}{l}30 \\
30 \\
30 \\
30\end{array}$ & $62 \pm 0.4$ & $\begin{array}{l}394 \\
431 \\
419 \\
338 \\
\end{array}$ & $\begin{array}{c}\text { Panigrahi et al. } \\
\text { (2020) }\end{array}$ \\
\hline & $\begin{array}{c}\text { Catering FW + } \\
\text { pretreated } \\
\text { parthenium } \\
\text { weed (PPW) } \\
\end{array}$ & $\begin{array}{l}\text { Batch } \\
(2.5 \mathrm{~L})\end{array}$ & $\begin{array}{c}\text { Mesophilic }(30 \pm 1 \\
\left.{ }^{\circ} \mathrm{C}\right)\end{array}$ & NR & NR & 60 & 62.2 & $\begin{array}{c}559 \mathrm{~mL} / \mathrm{L} . \mathrm{d} \\
\text { (maximum biogas } \\
\text { production rate) }\end{array}$ & $\begin{array}{c}\text { Tayyab et al. } \\
(2019)\end{array}$ \\
\hline & $\begin{array}{c}\text { FW + maize } \\
\text { husk }(\mathrm{MH}) \\
(\mathrm{w} / \mathrm{w}) \\
75: 25 \\
\end{array}$ & $\begin{array}{c}\text { CSTR } \\
(5 \mathrm{~L})\end{array}$ & Mesophilic $\left(37^{\circ} \mathrm{C}\right)$ & $\begin{array}{l}68 \\
27 \\
19 \\
15\end{array}$ & $\begin{array}{c}1 \mathrm{gVS} / \mathrm{L} . \mathrm{d} \\
2.5 \mathrm{gVS} / \mathrm{L} . \mathrm{d} \\
3.5 \mathrm{gVS} / \mathrm{L} . \mathrm{d} \\
4.5 \mathrm{gVS} / \mathrm{L} . \mathrm{d}\end{array}$ & $\begin{array}{l}120 \\
120 \\
120 \\
120 \\
\end{array}$ & $\begin{array}{l}80.7 \% \\
76.5 \% \\
74.3 \% \\
78.3 \% \\
\end{array}$ & $\begin{array}{l}400 \\
408 \\
447 \\
482 \\
\end{array}$ & $\begin{array}{l}\text { Owamah and } \\
\text { Izinyon (2015) }\end{array}$ \\
\hline & $\begin{array}{c}\text { FW + straw } \\
(\mathrm{w} / \mathrm{w}) \\
20: 80 \\
60: 40 \\
80: 20 \\
\end{array}$ & $\begin{array}{l}\text { Batch } \\
(1 \mathrm{~L})\end{array}$ & $\begin{array}{l}\text { Mesophilic } \\
\left(35^{\circ} \mathrm{C}\right)\end{array}$ & - & $\begin{array}{l}\text { Initial loading } \\
=5 \mathrm{~g} \mathrm{VS} / \mathrm{L}\end{array}$ & NR & NR & $\begin{array}{l}171 \\
299 \\
313 \\
\end{array}$ & $\begin{array}{l}\text { Yong et al., } \\
\quad(2015)\end{array}$ \\
\hline & 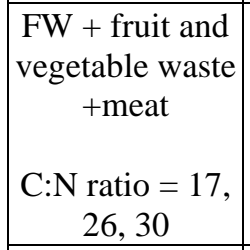 & $\begin{array}{l}\text { Batch } \\
(1 \mathrm{~L})\end{array}$ & $\begin{array}{l}\text { Mesophilic } \\
\quad(35 \mathrm{oC})\end{array}$ & N.R & $\begin{array}{l}\text { Initial loading } \\
=3.5 \mathrm{gVS} / \mathrm{L}\end{array}$ & 30 & $\begin{array}{l}38 \% \\
54 \% \\
71 \%\end{array}$ & $\begin{array}{l}0.352 \\
0.447 \\
0.679\end{array}$ & $\begin{array}{c}\text { Tanimu et al., } \\
\text { (2014) }\end{array}$ \\
\hline & $\begin{array}{c}\mathrm{FW}+\text { rain tree } \\
\text { leaf }(\mathrm{RTL}) \\
(\mathrm{w} / \mathrm{w}) \\
95: 5\end{array}$ & $\begin{array}{c}\text { Pilot scale one } \\
\text { stage } \\
(2500 \mathrm{~L}) \\
\text { Pilot scale } \\
\text { two stage } \\
(1000 \mathrm{~L}+ \\
2500 \mathrm{~L})\end{array}$ & $\begin{array}{l}\text { Mesophilic } \\
\left(35^{\circ} \mathrm{C}\right)\end{array}$ & 30 & $\begin{array}{l}6.8 \mathrm{~g} \mathrm{VS} / \mathrm{L} . \mathrm{d} \\
9.5 \mathrm{gVS} / \mathrm{L} . \mathrm{d}\end{array}$ & 112 & $\begin{array}{l}80.4 \% \\
89.2 \%\end{array}$ & 153 & $\begin{array}{c}\text { Ratanatamskul } \\
\text { and Manptech } \\
\text { (2016) }\end{array}$ \\
\hline
\end{tabular}




\begin{tabular}{|c|c|c|c|c|c|c|c|c|c|}
\hline $\begin{array}{l}\text { Types of co- } \\
\text { substrate }\end{array}$ & $\begin{array}{l}\text { Types of co- } \\
\text { digestion }\end{array}$ & $\begin{array}{l}\text { Types of } \\
\text { reactor }\end{array}$ & $\begin{array}{c}\text { Process } \\
\text { temperature/ } \\
\text { condition }\end{array}$ & HRT & OLR or $\mathrm{S} / \mathrm{I}$ & $\begin{array}{l}\text { Duration } \\
\text { (days) }\end{array}$ & $\begin{array}{c}\text { VS } \\
\text { removal } \\
(\%)\end{array}$ & $\begin{array}{c}\mathrm{CH}_{4} \text { yield } \\
\left(\mathrm{LCH}_{4} / \mathrm{kg} \mathrm{VS}\right)\end{array}$ & References \\
\hline & $\begin{array}{c}\text { FW + rice husk } \\
\text { (RH) Mixed to } \\
\text { obtain a C:N = } \\
28\end{array}$ & $\begin{array}{l}\text { Pilot scale plug } \\
\text { flow (80L) }\end{array}$ & $\begin{array}{l}\text { Mesophilic } \\
\quad\left(37^{\circ} \mathrm{C}\right)\end{array}$ & $\begin{array}{l}26 \\
25 \\
14\end{array}$ & $\begin{array}{l}5 \mathrm{gVS} / \mathrm{L} . \mathrm{d} \\
6 \mathrm{gVS} / \mathrm{L} . \mathrm{d} \\
9 \mathrm{gVS} / \mathrm{L} . \mathrm{d}\end{array}$ & $\begin{array}{l}27 \\
52 \\
30\end{array}$ & $\begin{array}{l}82.4 \% \\
73.1 \% \\
35.4 \%\end{array}$ & $\begin{array}{l}446 \mathrm{~L}_{\text {biogas }} / \mathrm{kg} \text { VS } \\
399 \mathrm{~L}_{\text {biogas }} / \mathrm{kg} \mathrm{VS} \\
215 \mathrm{~L}_{\text {biogas }} / \mathrm{kg} \mathrm{VS}\end{array}$ & $\begin{array}{l}\text { Jabeen et al., } \\
\quad(2015)\end{array}$ \\
\hline \multirow{4}{*}{ Sewage sludge } & \begin{tabular}{|c|} 
FW + dewatered \\
sludge (DS) \\
FW : DS \\
(VS ratio) \\
$30: 70$ \\
$50: 50$ \\
$70: 30$ \\
\end{tabular} & CSTR (6L) & $\begin{array}{l}\text { Mesophilic } \\
\quad\left(35^{\circ} \mathrm{C}\right)\end{array}$ & 20 days & $\begin{array}{l}6.3 \mathrm{gVS} / \mathrm{L} . \mathrm{d} \\
7.2 \mathrm{gVS} / \mathrm{L} . \mathrm{d} \\
7.6 \mathrm{gVS} / \mathrm{L} . \mathrm{d}\end{array}$ & NR & $\begin{array}{l}46 \% \\
58 \% \\
67 \%\end{array}$ & $\begin{array}{l}258 \\
332 \\
380\end{array}$ & $\begin{array}{l}\text { Dai et al., } \\
\text { (2013) }\end{array}$ \\
\hline & \begin{tabular}{|c|} 
FW + WAS \\
(TS ratio) \\
33.3:66.6 \\
33.3:66.6 \\
33.3:66.6 \\
\end{tabular} & $\begin{array}{l}\text { CSTR } \\
(2 \mathrm{~L})\end{array}$ & $\begin{array}{l}35 \\
45 \\
55 \\
\end{array}$ & 16.7 days & $2 \mathrm{gVS} / \mathrm{L} . \mathrm{d}$ & $\begin{array}{l}160 \\
178 \\
188 \\
\end{array}$ & $\begin{array}{l}62 \% \\
60 \% \\
58 \% \\
\end{array}$ & $\begin{array}{l}250 \\
290 \\
370 \\
\end{array}$ & $\begin{array}{l}\text { Gou et al., } \\
\text { (2014) }\end{array}$ \\
\hline & $\begin{array}{c}\text { FW + WAS } \\
(\mathrm{VS} \text { ratio) } \\
16.5: 83.5 \\
\text { FW + WAS } \\
(\mathrm{VS} \text { ratio) } \\
16.5: 83.5\end{array}$ & $\begin{array}{l}\text { Single stage } \\
\text { pilot CSTR ( } 20 \\
\text { tonnes) } \\
\text { Two stage pilot } \\
\text { CSTR ( } 4.5+ \\
15.5 \text { tonnes) }\end{array}$ & $\begin{array}{l}\text { Mesophilic } \\
\quad\left(35^{\circ} \mathrm{C}\right) \\
\text { Mesophilic } \\
\quad\left(35^{\circ} \mathrm{C}\right)\end{array}$ & 20 & $\begin{array}{c}0.85 \mathrm{~g} \mathrm{VS} / \mathrm{L} . \mathrm{d} \\
\mathrm{NR}\end{array}$ & 350 & $\begin{array}{l}46 \% \\
48 \%\end{array}$ & $\begin{array}{l}960 \mathrm{~L}_{\text {biogas }} / \mathrm{kg} \mathrm{VS} \\
440 \mathrm{~L}_{\text {biogas }} / \mathrm{kg} \mathrm{VS}\end{array}$ & $\begin{array}{l}\text { Zhang et al., } \\
\text { (2013b) }\end{array}$ \\
\hline & $\begin{array}{c}\text { Synthetic FW }+ \\
\text { waste activated } \\
\text { sludge (WAS) } \\
\text { (addition of } \\
\text { biochar) }\end{array}$ & $\begin{array}{l}\text { Batch } \\
(0.12 \mathrm{~L})\end{array}$ & $\begin{array}{l}\text { Thermophilic } \\
\left(55^{\circ} \mathrm{C}\right)\end{array}$ & NR & $\begin{array}{c}0.25 \\
0.75 \\
1.5 \\
2.25 \\
3.0\end{array}$ & 20 & NR & $\begin{array}{c}20 \\
50 \\
90 \\
150 \\
200 \\
\text { (cumulative methane } \\
\text { production, } \mathrm{mL} \text { ) }\end{array}$ & Li et al. (2018) \\
\hline
\end{tabular}




\begin{tabular}{|c|c|c|c|c|c|c|c|c|c|}
\hline $\begin{array}{l}\text { Types of co- } \\
\text { substrate }\end{array}$ & $\begin{array}{l}\text { Types of co- } \\
\text { digestion }\end{array}$ & $\begin{array}{l}\text { Types of } \\
\text { reactor }\end{array}$ & $\begin{array}{c}\text { Process } \\
\text { temperature/ } \\
\text { condition }\end{array}$ & HRT & OLR or $\mathrm{S} / \mathrm{I}$ & $\begin{array}{c}\text { Duration } \\
\text { (days) }\end{array}$ & $\begin{array}{c}\text { VS } \\
\text { removal } \\
(\%)\end{array}$ & $\begin{array}{c}\mathrm{CH}_{4} \text { yield } \\
\left(\mathrm{LCH}_{4} / \mathrm{kg} \mathrm{VS}\right)\end{array}$ & References \\
\hline \multirow{4}{*}{$\begin{array}{c}\text { Animal } \\
\text { manures/dung }\end{array}$} & $\begin{array}{c}\text { FW + cattle } \\
\text { slurry }(\mathrm{CS}) \\
(\mathrm{VS} \text { ratio }= \\
20: 80)\end{array}$ & $\begin{array}{l}\text { CSTR } \\
(75 \mathrm{~L})\end{array}$ & $\begin{array}{l}\text { Mesophilic } \\
\quad\left(36^{\circ} \mathrm{C}\right)\end{array}$ & 30 days & $2 \mathrm{gVS} / \mathrm{L}$. day & 308 & NR & 220 & $\begin{array}{l}\text { Zhang et al., } \\
\text { (2012) }\end{array}$ \\
\hline & $\begin{array}{c}\text { FW + dairy } \\
\text { manure }(\mathrm{DM}) \\
(\mathrm{VS} \text { ratio }= \\
50: 50)\end{array}$ & $\begin{array}{c}\text { CSTR } \\
(2 \mathrm{~L})\end{array}$ & $\begin{array}{l}\text { Mesophilic } \\
\quad\left(36^{\circ} \mathrm{C}\right)\end{array}$ & 80 days & $2 \mathrm{gVS} / \mathrm{L}$. day & 180 & NR & $\begin{array}{l}630 \text { (fine), } 560 \\
\text { (medium), } 470 \\
\quad \text { (coarse) }\end{array}$ & $\begin{array}{c}\text { Agyeman and } \\
\text { Tao (2014) }\end{array}$ \\
\hline & $\begin{array}{c}\mathrm{FW}+\text { chicken } \\
\text { manure }\end{array}$ & $\begin{array}{c}\text { CSTR } \\
(3.5 \mathrm{~L})\end{array}$ & $\begin{array}{l}\text { Mesophilic } \\
\quad\left(35^{\circ} \mathrm{C}\right)\end{array}$ & 35 days & $2.5 \mathrm{gVS} / \mathrm{L}$. day & 225 & NR & 508 & $\begin{array}{c}\text { Wang et al., } \\
\text { (2014) }\end{array}$ \\
\hline & $\begin{array}{c}\text { FW + cow dung } \\
(\mathrm{CD})+\text { piggery } \\
\text { dung (PD) } \\
(1: 2: 2)\end{array}$ & $\begin{array}{l}\text { CSTR } \\
(10 \mathrm{~L})\end{array}$ & Mesophilic & NR & NR & 30 & NR & $\begin{array}{c}\text { FW+CD+PD : } 0.67 \mathrm{~L} \\
\text { FW+CD: } 0.62 \mathrm{~L} \\
\text { FW+PD : } 0.58 \mathrm{~L} \\
\text { FW only : } 0.49 \mathrm{~L}\end{array}$ & $\begin{array}{c}\text { Oladejo et al. } \\
(2020)\end{array}$ \\
\hline
\end{tabular}

$\mathrm{NR}=$ not reported 


\section{$b, F W$ pretreatment}

Pretreatment and other in-situ procedures (such as co-digestion and addition of additives) are two methods that have been studied to enhance the hydrolysis rate (Panigrahi and Dubey, 2019). Pretreatment is required to convert complex structures such as cellulose, hemicellulose, and lignin, which are difficult for microbes to degrade, into biodegradable substances that can be digested by microbes (Siddique and Wahid, 2018). This method is used to boost methane production by increasing chemical oxygen demand and releasing the substrates' intracellular nutrients (Neshat et al., 2017). As a pretreatment stage happens early in the digestion process, it can minimize the level of difficulty in the hydrolysis stage, resulting in a more efficient digestion process. An effective pretreatment should be able to: (i) maintain organic components in biomass; ii) promote hydrolysis progress; iii) prevent the development of hazardous and/or inhibitory compounds; iv) be environmentally friendly, and v) be economically feasible (Derman et al., 2018; Choi et al., 2019). There are various effective pretreatment methods to increase biogas production especially methane through the anaerobic digestion process. These include physical, chemical, biological, and combination of these methods.

Mechanical, freezing/thawing, ultrasonic, microwave, and thermal/hydrothermal treatment are examples of physical pretreatment procedures. The purpose of physical treatments is to alter the morphological structure of substances in order to improve the solubilization and hydrolysis of solid organic materials (Ma et al., 2018). The application of the mechanical pretreatment method can help to boost the effectiveness of the anaerobic digestion process and increase biogas production especially methane. This method has the potential to reduce the size of the substrate particles and increase the surface area of the substrate to be exposed to anaerobic bacterial activity. As reported by Panigrahi and Dubey (2019), Braguglia et al. (2018), and Ariunbaatar et al. (2014), several mechanical methods are often used to pretreat the substrate before introduction into the anaerobic digester. These include grinding, bead milling, high-pressure homogenizer (HPH), stirred ball mills, ultrasonic, and the jetting and colliding method. The mechanical pretreatment method is a physical process that does not involve the addition of chemical substances. Mechanical pretreatment improves the kinetics of biological processes by altering the chemical composition, reducing particle size, crystallinity, polymerization, the release of dissolved organic matter (Panigrahi and Dubey, 2019), as well as improving the substrate's surface area to volume ratio and pore volume (Jain et al., 2015). A larger surface area allows for better contact between the substrate and the anaerobic bacteria, which improves the AD process. Ultrasonic (Rasapoor et al., 2016; Menon et al., 2016; Deepanraj et al., 2017), mechanical grinding (Izumi et al., 2010; Agyeman and Tao, 2014), and freezing/thawing are some of the physical pretreatment procedures employed on FW (Stabnikova et al., 2008).

Thermal pretreatment enhances the $\mathrm{AD}$ process by disinfecting by sterilization ( $\mathrm{Li}$ and Jin, 2015), deflocculating macromolecules, and enhancing dewaterability (Jin et al., 2016), solubilizing refractory particles (Ariunbaatar et al., 2015b), and lowering exogenous pollution, but it also inactivates methanogenic bacteria in the raw material. Thermal pretreatment is often evaluated in terms of soluble COD, VFA, and biogas generation. The existence of oil in OFMSW, on the other hand, necessitates the examination of both physical and chemical properties following thermal pretreatment (Jin et al., 2016) The primary affecting parameters in the thermal pretreatment method are treatment temperature, treatment time, and heat transfer mode, but treatment temperature is more essential than the duration of treatment (Panigrahi and Dubey, 2019). Thermal 
pretreatment (the only temperature is regulated, for example in a hot air oven, microwave, or hot water bath) and hydrothermal pretreatment (both temperature and pressure are regulated such as autoclave pretreatment) are the two types of thermal pretreatment methods. Microwave pretreatment for organic solid waste is more successful than autoclave pretreatment in terms of methane production (Tampio et al., 2014; Pecorini et al., 2016). Various studies related to thermal pretreatment have been carried out at temperatures ranging from 50 to $250{ }^{\circ} \mathrm{C}$. According to Ariunbaatar et al. (2014), the effects of thermal pretreatment are dependent on the kind of substrate or feedstock used and the temperature range involved. Although the degree of solubilization shows a significant effect when higher temperatures $\left(>110{ }^{\circ} \mathrm{C}\right)$ and longer retention times are applied to the substrate during thermal pretreatment, it cannot be directly attributed to the final energy yield (Braguglia et al., 2018). In some cases, higher solubilization can also be achieved at a low temperature $\left(<110{ }^{\circ} \mathrm{C}\right)$ but requires a longer retention time. According to Ariunbaatar et al. (2014), many studies related to thermal pretreatment performed at low temperatures $\left(<110{ }^{\circ} \mathrm{C}\right)$ i.e $70{ }^{\circ} \mathrm{C}$. This is based on EU Regulation EC1772/2002 which requires organic solid waste to be pretreated at $70^{\circ} \mathrm{C}$ at least 1 hour. Thermal pretreatment on FW has been carried out by several previous researchers such as Gnaoui et al. (2020), Li et al. (2017), Li and Jin (2015), and Tampio et al. (2014).

In chemical pretreatment, chemicals such as strong acids, alkalis, or oxidants have been used as pretreatment methods to break down the organic constituents by hydrolyzing the cell walls and membranes resulting in higher solubility of organic matter in the cells. To solve problems related to sludge solubilization efficiently with little or no energy demand, acid and alkali pretreatment become the appropriate option in addition to producing pathogen-free digestate. According to Sarto et al. (2019), acid pretreatment aims to weaken covalent hydrogen bonds and van der Waals forces in order to solubilize hemicellulose, break down cellulose, and hydrolyze hemicellulose into monosaccharides. Dilute acid was chosen for this pretreatment because it is less poisonous, less corrosive, and less costly, as well as requiring fewer neutralizing reagents and involving cheaper reactor construction material costs. The lignocellulosic substrates such as agricultural wastes, wood chips, crop waste, and paper waste have all been subjected to the dilute acid pretreatment approach. Various types of lignocellulosic fractions of MSW have been treated with dilute sulfuric acid $\left(\mathrm{H}_{2} \mathrm{SO}_{4}\right)$, dilute nitric acid $\left(\mathrm{HNO}_{3}\right)$, dilute hydrochloric acid $(\mathrm{HCl})$, dilute phosphoric acid $\left(\mathrm{H}_{3} \mathrm{PO}_{4}\right)$, dilute glycolic acid $\left(\mathrm{C}_{2} \mathrm{H}_{4} \mathrm{O}_{3}\right)$, and dilute oxalic acid $\left(\mathrm{C}_{2} \mathrm{H}_{2} \mathrm{O}_{4}\right)$, however, because of its inexpensive cost, dilute $\mathrm{H}_{2} \mathrm{SO}_{4}$ is the most often used (Panigrahi and Dubey, 2019). During alkaline pretreatment, acetyl groups are removed and uronic acid is substituted, making cellulose and hemicellulose more accessible to hydrolytic enzymes. Pretreatment with alkaline improves the internal surface area, degrades lignin, and destroys the lignin-carbohydrate bond. Alkaline reagents such as $\mathrm{NaOH}, \mathrm{KOH}, \mathrm{Mg}(\mathrm{OH})_{2}, \mathrm{Ca}(\mathrm{OH})_{2}$, and $\mathrm{NH}_{4} \mathrm{OH}$ have been employed in previous investigations (Bazargan et al., 2015). In terms of COD solubilization, $\mathrm{NaOH}$ is the most effective of these chemicals, followed by $\mathrm{KOH}, \mathrm{Mg}(\mathrm{OH})_{2}$, and $\mathrm{Ca}(\mathrm{OH})_{2}$ (Panigrahi and Dubey, 2019). By increasing the internal surface area of biomass, $\mathrm{NaOH}$ has the maximum ability to reduce crystallinity and degree of polymerization, as well as boost biomass degradability. Because part of the chemicals is used by the biomass during alkaline pretreatment, a larger chemical dosage is required. However, it has been noted that using $\mathrm{NaOH}$ can raise the cost of pretreatment and that a high concentration of $\mathrm{Na}^{+}$ can impede the $\mathrm{AD}$ process. When comparing $\mathrm{NaOH}$ to $\mathrm{Ca}(\mathrm{OH})_{2}, \mathrm{Ca}(\mathrm{OH})_{2}$ is preferable since it is less expensive, safer, and easier to extract from aqueous solutions using $\mathrm{CO}_{2}$. 
Apart from acid and alkaline pretreatment, the oxidation process is one of the pretreatment methods found in chemical pretreatment. This method includes ozonation, peroxidation, and peracetic acid. Ozonation and peroxidation pretreatment methods are very useful in sludge stabilization. The use of ozone will cause cellular disruption, flocs disintegration, and high COD solubilization (Salihu and Alam, 2016). There are some disadvantages of this pretreatment method which require high capital. In addition, higher ozonation will cause the formation of soluble compounds that will have a damaging effect when released into the environment. The use of the peroxidation method is also limited due to the factors such as low $\mathrm{pH}$, requiring proper handling, and special equipment and corrosion problems (Salihu and Alam, 2016). Therefore, most researchers prefer acid and alkaline pretreatment methods to treat organic waste that will be used as a feedstock for the anaerobic digestion process because both methods are easier with little or no energy demand. There are several researchers such as Junoh et al. (2015), Naran et al. (2016), Jang et al. (2015), and Yue et al. (2020) who used chemical methods (acid, alkaline, and ozonation) to perform $\mathrm{FW}$ pretreatment to increase biogas production during $\mathrm{AD}$ process (refer Table 5).

According to Panigrahi and Dubey (2019), the major objective of biological pretreatment is to improve the digestibility of complex waste by eliminating covalent cross-linkages and non-covalent interactions between hemicelluloses and lignin, as well as increasing particle surface area. Various types of feedstocks such as wood and grass, waste office paper, lignocellulosic substrate, agricultural residues, hardwood, FW, and MSW are suitable for biological pretreatment before the AD process. Biological pretreatment is an environmentally friendly process but time-consuming and that requires a longer retention time. During the pretreatment process, the microbes utilize free and easily accessible carbohydrates as their primary carbon source. Because the microbes compete with the native microorganisms during the pretreatment process, maintaining a pure culture of bacteria and optimizing their growth conditions for an FW pretreatment can be difficult (Banu et al., 2020). In biological pretreatment, the primary affecting parameters are incubation temperature and time, moisture content, type of biological pretreatment, $\mathrm{pH}$ of the medium, and substrate particle size. Aeration of $\mathrm{FW}$ is another biological pretreatment option that can boost hydrolysis rates. Aeration changes the biomass community in the FW and slows the build-up of volatile fatty acids, as well as hydrolyzing resistant substrates by mobilizing enzymes. Not limited to microbial systems alone, the biological pretreatment also involves enzymes such as amylase, lipase, protease, and cellulase which works to accelerate hydrolysis through enzymatic catalysis and further promote methane production through an anaerobic digestion process. The utilization of enzymes in biological pretreatment promotes the solubilization process that occurs earlier within the system than in the microbial process which requires an acclimatization period. Enzymatic pretreatment is one of the most promising biological pretreatment methods in which the rate of hydrolysis for organic residues can be improved further before anaerobic digestion. Before the digestion process, enzymes may be introduced to the substrate as a pretreatment or directly added to the digester. According to Carrere et al. (2016), the addition of enzymes directly into the digester is a common procedure in the full-scale scenario. Although enzymatic pretreatment requires less input energy than mechanical and thermal pretreatment methods without involving the addition of chemicals, other factors as the main issues would be the price, enzyme selection (lipase or glucoamylase), and process efficiency. 
Table 5. Summary for some of the pretreatment studies involving mechanical, chemical, thermal, biological and combination of various pretreatment methods reported on $\mathrm{FW}$

\begin{tabular}{|c|c|c|c|c|c|}
\hline $\begin{array}{c}\text { Type of } \\
\text { organic waste }\end{array}$ & $\begin{array}{l}\text { Pretreatment } \\
\text { conditions }\end{array}$ & $\begin{array}{l}\text { Type of AD } \\
\text { system }\end{array}$ & Impact of pretreatment & Anaerobic digestion performance & References \\
\hline $\begin{array}{l}\text { Food waste } \\
\quad(\mathrm{FW})\end{array}$ & $\begin{array}{l}\text { MECHANICAL } \\
\text { Grinding }\end{array}$ & $\begin{array}{l}\text { Mesophilic (semi- } \\
\text { continuous) }\end{array}$ & $\begin{array}{l}\text { reduction in the average size of } \mathrm{FW} \\
\text { particles to } 2.5,4 \text { and } 8 \mathrm{~mm}\end{array}$ & $\begin{array}{l}\bullet \quad \text { the range of methane yield } \\
\text { produced for particle sizes of } 2.5,4 \text {, and } 8 \\
\text { mm is in the range between } 510-630,470- \\
560 \text { and } 460-470 \mathrm{~mL} \mathrm{CH}_{4} / \mathrm{g} \text { VS. }\end{array}$ & $\begin{array}{l}\text { Agyeman and } \\
\text { Tao (2014) }\end{array}$ \\
\hline $\begin{array}{l}\text { Food waste } \\
\quad(\mathrm{FW})\end{array}$ & $\begin{array}{c}\text { MECHANICAL } \\
\text { Bead milling }(1000 \mathrm{rpm})\end{array}$ & $\begin{array}{l}\text { Mesophilic } \\
\quad \text { (batch) }\end{array}$ & $\begin{array}{l}\text { the mean particle size of the FW } \\
\text { decreased from } 0.843 \text { to } 0.391 \mathrm{~mm} \text {. } \\
\text { increased by } 40 \% \text { of the total COD. }\end{array}$ & - $\quad$ methane yield has increased by 28 & $\begin{array}{l}\text { Izumi et al., } \\
\quad(2010)\end{array}$ \\
\hline $\begin{array}{l}\text { Food waste } \\
\quad(\text { FW) }\end{array}$ & $\begin{array}{c}\text { MECHANICAL } \\
\text { High voltage pulse } \\
\text { discharge (HVPD) } \\
\text { Voltage }=40 \mathrm{kV} \\
\text { Electrode distance }=5 \\
\text { mm } \\
\text { Pulse frequency = } 400 \\
\mathrm{~Hz} \\
\text { Duration }=30 \mathrm{~min} \\
\end{array}$ & $\begin{array}{l}\text { Mesophilic } \\
\quad \text { (batch) }\end{array}$ & $\begin{array}{l}\text { - the COD removal rate of FW } \\
\text { pretreated with HVPD was over } 100 \% \text {, } \\
\text { significantly greater than the control. } \\
\text { more VFAs would be neutralized } \\
\text { due to the greater ammonia content in the } \\
\text { reactor after HVPD pretreatment. }\end{array}$ & $\begin{array}{l}\text { - the methane yield increased by } \\
34.6 \% \text { from } 234 \mathrm{~mL} \mathrm{CH}_{4} / \mathrm{gCOD}_{\text {removed }} \text { to } \\
315 \mathrm{~mL} \mathrm{CH}_{4} / \mathrm{gCOD}_{\text {removed. }}\end{array}$ & Zou et al. (2016) \\
\hline $\begin{array}{l}\text { Food waste } \\
\quad(\text { FW) }\end{array}$ & $\begin{array}{c}\text { MECHANICAL } \\
\text { Microwave } \\
\text { Temperature }=100^{\circ} \mathrm{C} \\
\text { Power }=600 \mathrm{~W}\end{array}$ & $\begin{array}{l}\text { Mesophilic } \\
\quad \text { (batch) }\end{array}$ & $\begin{array}{l}\text { Proteins and polysaccharides were } \\
\text { degraded by Proteiniborus and } \\
\text { Parabacteroides, respectively. } \\
\text { - } \quad \text { Bacteroides was the only bacteria } \\
\text { that dominated in the co-digestion system. } \\
\text { - At the active methane generation } \\
\text { phase, Methanosphaera predominated in } \\
\text { microwave pretreated FW. }\end{array}$ & $\begin{array}{l}\bullet \quad \text { There was an increase in methane } \\
\text { yield from } 297 \mathrm{~mL} \mathrm{CH}_{4} / \mathrm{g} \mathrm{VS}_{\text {added }} \text { to } 316 \mathrm{~mL} \\
\mathrm{CH}_{4} / \mathrm{g} \mathrm{VS}_{\text {added }}\end{array}$ & $\begin{array}{l}\text { Zhang et al. } \\
\qquad(2016)\end{array}$ \\
\hline $\begin{array}{l}\text { FW from the } \\
\text { campus } \\
\text { cafeteria }\end{array}$ & $\begin{array}{c}\text { MECHANICAL } \\
\text { Ultrasonic } \\
\end{array}$ & $\begin{array}{l}\text { Mesophilic } \\
\quad \text { (batch) }\end{array}$ & $\begin{array}{l}\text { There was an increase of } 7 \% \text { in } \\
\text { SCOD. }\end{array}$ & $\begin{array}{l}\bullet \quad \text { Produce } 149 \mathrm{~mL} \mathrm{H}_{2} / \mathrm{gVS}_{\text {added }} \\
\text { (sonicated) and } 85 \mathrm{~mL} \mathrm{H}_{2} / \mathrm{gVS}_{\text {added }} \text { (non- } \\
\text { sonicated) } \\
\end{array}$ & $\begin{array}{l}\text { Gadhe et al., } \\
\text { (2014) }\end{array}$ \\
\hline
\end{tabular}




\begin{tabular}{|c|c|c|c|c|c|}
\hline $\begin{array}{c}\text { Type of } \\
\text { organic waste }\end{array}$ & $\begin{array}{l}\text { Pretreatment } \\
\text { conditions }\end{array}$ & $\begin{array}{c}\text { Type of AD } \\
\text { system }\end{array}$ & Impact of pretreatment & Anaerobic digestion performance & References \\
\hline $\begin{array}{c}\text { (rice, } \\
\text { vegetables, } \\
\text { fruit peels, } \\
\text { other residues) }\end{array}$ & $\begin{array}{c}\text { Power }=1200 \mathrm{~W} \\
\text { Ultrasonic density }=1.5 \\
\mathrm{~W} / \mathrm{mL} \\
\mathrm{SE}=\text { varied depends on } \\
\text { sonication duration and } \\
\mathrm{TS} \\
\text { Frequency }=20 \mathrm{kHz} \\
\begin{array}{c}\text { Sonication duration }=15 \\
\text { min }\end{array} \\
\end{array}$ & & & $\begin{array}{l}\text { - The biogas production has been } \\
\text { enhanced with a } 75.3 \% \text { increase in } \\
\text { hydrogen content. }\end{array}$ & \\
\hline $\begin{array}{l}\text { FW } \\
\text { co-digested } \\
\text { with poultry } \\
\text { manure }\end{array}$ & \begin{tabular}{|c|} 
MECHANICAL \\
Ultrasonic \\
Power $=130 \mathrm{~W}$ \\
$\mathrm{SE}=\mathrm{N} . \mathrm{R}$ \\
Frequency $=20 \mathrm{kHz}$ \\
$\begin{array}{c}\text { Sonication duration }=30 \\
\text { min }\end{array}$ \\
\end{tabular} & $\begin{array}{l}\text { Thermophilic } \\
\text { (batch) }\end{array}$ & $\begin{array}{c}\bullet \text { TS, VS and COD removal } \\
\text { efficiency recorded } 61.83 \%, 65.21 \% \text { and } \\
54.66 \% \text {, respectively. }\end{array}$ & $\begin{array}{l}\text { Produce maximum cumulative } \\
\text { biogas of } 9926 \mathrm{~mL} \text { with methane } \\
\text { composition of } 62.47 \%\end{array}$ & $\begin{array}{c}\text { Deepanraj et al., } \\
\text { (2017) }\end{array}$ \\
\hline Kitchen waste & \begin{tabular}{|c|} 
MECHANICAL \\
Ultrasonic \\
UD $=0.2-0.6 \mathrm{~W} / \mathrm{L}$ \\
SE $=5000-10000 \mathrm{~kJ} / \mathrm{kg}$ \\
$\mathrm{TS}$ \\
Frequency $=20 \mathrm{kHz}$ \\
Sonication duration $=$ \\
$10-30$ min \\
Power $=$ N.R
\end{tabular} & $\begin{array}{l}\text { Mesophilic } \\
\quad \text { (batch) }\end{array}$ & $\begin{array}{l}\text { There was an increase about } 93 \% \text {, } \\
83 \% \text { and } 37 \% \text { in TVFA when the kitchen } \\
\text { waste with TS of } 6 \%, 8 \% \text { and } 10 \% \text { was } \\
\text { sonicated for } 30 \text { min, respectively. }\end{array}$ & $\begin{array}{c}\text { The maximum biogas yield produced after } \\
72 \mathrm{~h} \text { of digestion ranged between } 220-440 \\
\mathrm{~mL} / \mathrm{gVS} \text { at this condition }: 5000 \mathrm{~kJ} / \mathrm{kg} \text { TS- } \\
10,000 \mathrm{~kJ} / \mathrm{kg} \mathrm{TS}, 6 \% \mathrm{TS} \text {. }\end{array}$ & $\begin{array}{c}\text { Rasapoor et al. } \\
\text { (2016) }\end{array}$ \\
\hline Canteen FW & $\begin{array}{c}\text { MECHANICAL } \\
\text { Ultrasonic } \\
\text { Power }=100 \mathrm{~W} \\
\text { SE }=\text { N.R } \\
\text { Frequency }=20 \mathrm{kHz} \\
\end{array}$ & $\begin{array}{l}\text { Thermophilic } \\
\text { (batch) }\end{array}$ & $\begin{array}{l}\text { Reduction of processing time to } 38 \mathrm{~h} \\
\text { from the 60-80h needed in normal operation. } \\
\text { - } \quad \text { No significant improvement in } \\
\text { either SCOD or VFA production }\end{array}$ & $\begin{array}{l}\qquad \quad \text { There was an increase in total } \\
\text { biogas production with } 52 \% \mathrm{H}_{2} \text { and } 47 \% \\
\mathrm{CO}_{2} .\end{array}$ & $\begin{array}{c}\text { Menon et al. } \\
(2016)\end{array}$ \\
\hline
\end{tabular}

APPLIED ECOLOGY AND ENVIRONMENTAL RESEARCH 19(6):4795-4847.

http://www.aloki.hu • ISSN 15891623 (Print) • ISSN 17850037 (Online)

DOI: http://dx.doi.org/10.15666/aeer/1906 47954847

(c) 2021, ALÖKI Kft., Budapest, Hungary 


\begin{tabular}{|c|c|c|c|c|c|}
\hline $\begin{array}{c}\text { Type of } \\
\text { organic waste }\end{array}$ & $\begin{array}{l}\text { Pretreatment } \\
\text { conditions }\end{array}$ & $\begin{array}{l}\text { Type of AD } \\
\text { system }\end{array}$ & Impact of pretreatment & Anaerobic digestion performance & References \\
\hline & $\begin{array}{c}\text { Sonication duration }=15 \\
-45 \mathrm{~min}\end{array}$ & & & & \\
\hline $\begin{array}{l}\text { Food waste } \\
\qquad(\mathrm{FW})\end{array}$ & \begin{tabular}{|c|} 
CHEMICAL \\
Alkaline pretreatment \\
$\left(\begin{array}{c}40-190 \text { meq/L } \mathrm{Ca}(\mathrm{OH})_{2} \\
1-6 \text { hours })\end{array}\right.$ \\
\end{tabular} & $\begin{array}{l}\text { Mesophilic } \\
\quad \text { (batch) }\end{array}$ & $\begin{array}{c}\text { COD solubilization was optimum at } \\
166.98 \mathrm{meq} / \mathrm{L} \text { (equivalent to } 6.1 \mathrm{~g} \\
\left.\mathrm{Ca}(\mathrm{OH})_{2} / \mathrm{L}\right) \text { for } 1 \text { hour. }\end{array}$ & $\begin{array}{l}\text { the methane production of } 864.19 \\
\mathrm{~mL} / \mathrm{g} \mathrm{VS} \text { destructed was obtained with an } \\
\text { increase of } 20 \% \text { compared to untreated } \mathrm{FW} \text {. }\end{array}$ & $\begin{array}{l}\text { Junoh et al. } \\
\quad(2016)\end{array}$ \\
\hline Food waste & \begin{tabular}{|c|} 
CHEMICAL \\
\\
Alkaline pretreatment \\
Alkali concentration= \\
$0.4 \mathrm{~N} \mathrm{NaOH}$ \\
$\mathrm{pH}=12.7$ \\
Duration $=1$ hour \\
\end{tabular} & $\begin{array}{l}\text { Mesophilic } \\
\quad \text { (batch) }\end{array}$ & $\begin{array}{l}\text { better VS and COD solubilization } \\
\text { was obtained, which increased CH4 } \\
\text { recovery. }\end{array}$ & $\begin{array}{l}\text { there was an increase in methane } \\
\text { yield }(25 \%) \text { from } 271.7 \text { to } 339.2 \mathrm{~mL} \\
\mathrm{CH}_{4} / \mathrm{gVS}_{\text {removed }} \text { when alkaline pretreatment } \\
\text { was performed on } \mathrm{FW} \text {. }\end{array}$ & $\begin{array}{l}\text { Naran et al. } \\
\quad(2016)\end{array}$ \\
\hline $\begin{array}{l}\text { Food waste } \\
\qquad(\mathrm{FW})\end{array}$ & $\begin{array}{c}\text { CHEMICAL } \\
\text { Alkaline pretreatment } \\
\text { Alkali concentration = } \\
0.4 \mathrm{~N} \mathrm{NaOH} \\
\mathrm{pH}=12.0 \\
\text { Duration }=30 \text { hours }\end{array}$ & $\begin{array}{l}\text { Mesophilic } \\
\quad \text { (batch) }\end{array}$ & $\begin{array}{l}\text { - } \quad \text { the VS reduction recorded after } \\
\text { alkaline pretreatment was } 51 \pm 4.0 \% \text {. }\end{array}$ & $\begin{array}{l}-\quad \text { the resulting hydrogen yield was } \\
162 \mathrm{~mL} \mathrm{H}_{2} / \mathrm{g} \mathrm{VS}_{\text {added. }}\end{array}$ & $\begin{array}{l}\text { Jang et al. } \\
\quad(2016)\end{array}$ \\
\hline $\begin{array}{l}\text { Food waste } \\
\quad(\mathrm{FW})\end{array}$ & $\begin{array}{c}\text { CHEMICAL } \\
\text { Ozone pretreatment } \\
\text { Flow rate }=30 \mathrm{~mL} / \mathrm{min} \\
\text { Ozone concentrations }= \\
0,0.02,0.05,0.2 \text { and } 0.8 \\
\text { g-O3/g-TVS. } \\
\text { Pretreatment time }=0 \\
1.5,3.75,15,60 \mathrm{~min}\end{array}$ & $\begin{array}{l}\text { Mesophilic } \\
\quad \text { (batch) }\end{array}$ & \begin{tabular}{|c|} 
When the ozone content in the \\
pretreatment was increased to $0.8 \mathrm{~g}-\mathrm{O} 3 / \mathrm{g}$ - \\
TVS, the decomposition rate of glycerol \\
trioleate into hexadecanoic acid and \\
tetradecanoic acid increased to $78.6 \%$. \\
After ozonation pretreatment, the \\
coating of methanogens by lipids during the \\
anaerobic digestion process was significantly \\
reduced. \\
When food waste (carbohydrate \\
$45.7 \%$, protein $21.4 \%$, lipid $28.1 \%$ ) and
\end{tabular} & \begin{tabular}{|} 
At a concentration of $0.8 \mathrm{~g}-\mathrm{O} 3 / \mathrm{g}-$ \\
TVS, the methane yield from glycerol \\
trioleate increased by $81.9 \%$ to $946.5 \mathrm{~mL} / \mathrm{g}$ \\
TVS after dark hydrogen fermentation. \\
Because ozone oxidization \\
damaged most small-molecular \\
carbohydrates and a portion of proteins, \\
excessive ozone pretreatment $(0.05 \mathrm{~g}-\mathrm{O} 3 / \mathrm{g}-$ \\
TVS) lowered not only hydrogen yield but \\
also methane yield.
\end{tabular} & $\begin{array}{l}\text { Yue et al. } \\
(2020)\end{array}$ \\
\hline
\end{tabular}




\begin{tabular}{|c|c|c|c|c|c|}
\hline $\begin{array}{c}\text { Type of } \\
\text { organic waste }\end{array}$ & $\begin{array}{l}\text { Pretreatment } \\
\text { conditions }\end{array}$ & $\begin{array}{l}\text { Type of AD } \\
\text { system }\end{array}$ & Impact of pretreatment & Anaerobic digestion performance & References \\
\hline & & & $\begin{array}{c}\text { glycerol trioleate were combined with a total } \\
\text { volatile solids (TVS) ratio of } 1: 1, \text { an } \\
\text { ozonation pretreatment of } 0.02 \text {-O3/g-TVS } \\
\text { resulted in the maximum energy conversion } \\
\text { efficiency of } 78.7 \% \text { through two-stage dark } \\
\text { hydrogen fermentation and anaerobic } \\
\text { digestion. }\end{array}$ & & \\
\hline $\begin{array}{l}\text { Food waste } \\
\quad(\mathrm{FW})\end{array}$ & $\begin{array}{c}\text { THERMAL } \\
\text { Autoclave at } 160{ }^{\circ} \mathrm{C}, 6.2 \\
\text { bar }\end{array}$ & $\begin{array}{c}\text { Mesophilic (semi- } \\
\text { continuous) }\end{array}$ & 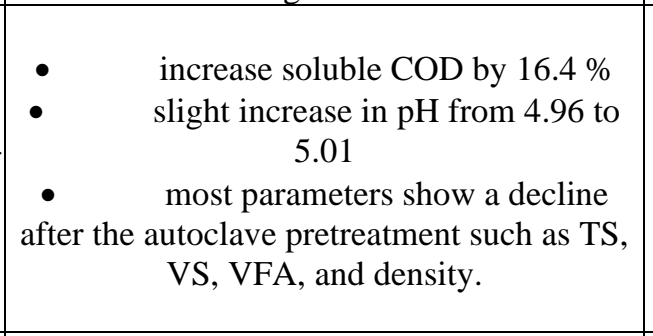 & 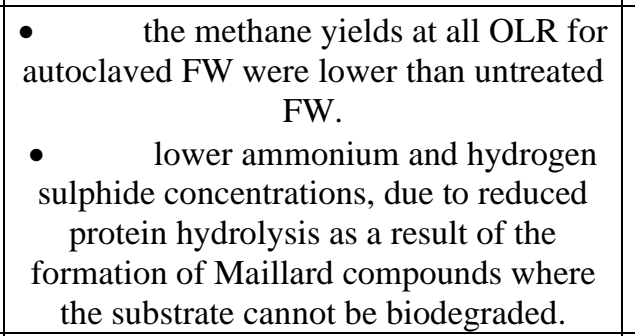 & $\begin{array}{l}\text { Tampio et al. } \\
\text { (2014) }\end{array}$ \\
\hline $\begin{array}{l}\text { Kitchen waste } \\
\qquad(\mathrm{KW})\end{array}$ & $\begin{array}{c}\text { THERMAL } \\
\text { Pretreatment condition }= \\
70 \text { min at } 55-90^{\circ} \mathrm{C} \text { and } \\
50 \text { min at } 120-160^{\circ} \mathrm{C} .\end{array}$ & $\begin{array}{l}\text { Mesophilic } \\
\text { (batch) }\end{array}$ & $\begin{array}{c}\text { improve the breakdown efficiency } \\
\text { of crude protein (CP), fat, oil and grease } \\
\text { (FOG), volatile solid (VS), and volatile fatty } \\
\text { acids (VFA), according to the kinetics } \\
\text { results. } \\
\text { had no effect on the ultimate protein } \\
\text { content, but it did reduce the FOG } \\
\text { degradation potential (7-36\%) and } \\
\text { lengthened the lag phase for protein and FOG } \\
\text { degradation by 35-65\% and } 11-82 \%, \\
\text { respectively, as compared to untreated KW. } \\
\text { the reduction in CP rose } \\
\text { tremendously with the efficiency of FOG } \\
\text { removal. }\end{array}$ & \begin{tabular}{|c|} 
- The removal efficiency of VS and \\
other organics (CP and FOG) enhanced \\
cumulative biogas yield in a linear and \\
exponential way.
\end{tabular} & Li et al. (2017) \\
\hline $\begin{array}{l}\text { Food waste } \\
\text { (FW) }\end{array}$ & $\begin{array}{l}\text { THERMAL } \\
\text { Temperatures }=60,80, \\
\text { and } 100 \circ \mathrm{C}\end{array}$ & $\begin{array}{c}\text { Mesophilic } \\
\text { (semi-continuous) }\end{array}$ & \begin{tabular}{|c|} 
Soluble COD was raised as a result \\
of temperature and time treatment, reaching \\
$68.54 \pm 2.4 \mathrm{mg} / \mathrm{L}$ at $\left(100{ }^{\circ} \mathrm{C}, 30 \mathrm{~min}\right)$, which \\
was $43.41 \%$ greater than the control.
\end{tabular} & \begin{tabular}{|l}
- \\
Anaerobic (AD) digestion of \\
thermally pretreated FW at $100{ }^{\circ} \mathrm{C}$ for 30 \\
min produced $382.82 \mathrm{~mL} \mathrm{STP} \mathrm{CH}_{4} / \mathrm{g}$ VS of
\end{tabular} & $\begin{array}{l}\text { Gnaoui et al. } \\
\quad(2020)\end{array}$ \\
\hline
\end{tabular}

APPLIED ECOLOGY AND ENVIRONMENTAL RESEARCH 19(6):4795-4847.

http://www.aloki.hu • ISSN 15891623 (Print) • ISSN 17850037 (Online)

DOI: http://dx.doi.org/10.15666/aeer/1906_47954847

( 2021 , ALÖKI Kft., Budapest, Hungary 


\begin{tabular}{|c|c|c|c|c|c|}
\hline \multirow[t]{2}{*}{$\begin{array}{c}\text { Type of } \\
\text { organic waste }\end{array}$} & $\begin{array}{l}\text { Pretreatment } \\
\text { conditions }\end{array}$ & $\begin{array}{c}\text { Type of AD } \\
\text { system }\end{array}$ & Impact of pretreatment & Anaerobic digestion performance & References \\
\hline & $\begin{array}{c}\text { Duration }=\underset{\min }{15,30} \text { and } 45 \\
\end{array}$ & & $\begin{array}{l}\text { Thermal pretreatment reduced the } \\
\text { percentage of VS as compared to raw FW. }\end{array}$ & $\begin{array}{l}\text { methane which was } 23.68 \% \text { higher than } \\
\text { untreated FW. } \\
\text { Biodegradability was improved by } \\
9.8 \% \text { from } 83.23 \% \text { to } 91.44 \% \text {. } \\
\end{array}$ & \\
\hline $\begin{array}{l}\text { Kitchen waste } \\
\text { (KW) }\end{array}$ & \begin{tabular}{|} 
THERMAL \\
Temperature $=55,70$ \\
$90,120,140$ and $160^{\circ} \mathrm{C}$
\end{tabular} & $\begin{array}{l}\text { Mesophilic } \\
\quad \text { (batch) }\end{array}$ & $\begin{array}{l}\bullet \quad \text { the increase in TS and VS } \\
\text { solubilization rate at } 55-120{ }^{\circ} \mathrm{C}(26.63 \% \text { and } \\
49.21 \%, \text { respectively) but decreased when } \\
\text { the temperature increased to } 140-160^{\circ} \mathrm{C} \\
\text { during acidification. }\end{array}$ & $\begin{array}{l}\text { reduce the retention time required } \\
\text { for anaerobic acidification by } 5 \text { days. } \\
\text { at temperatures ranging from } 50- \\
70{ }^{\circ} \mathrm{C} \text { and } 140-160{ }^{\circ} \mathrm{C} \text {, the organic removal } \\
\text { rate and biogas production for subsequent } \\
\text { anaerobic digestion showed a slight } \\
\text { reduction. } \\
\text { at a temperature of } 90 \text { and } 120^{\circ} \mathrm{C} \text {, } \\
\text { a better result was achieved. }\end{array}$ & $\begin{array}{l}\mathrm{Li} \text { and Jin } \\
\text { (2015) }\end{array}$ \\
\hline $\begin{array}{l}\text { Food waste } \\
\qquad(\mathrm{FW})\end{array}$ & $\begin{array}{c}\text { BIOLOGICAL } \\
\text { Aeration } \\
\text { Aeration in } 10 \mathrm{~L} \text { reactor } \\
\text { Temperature }=40{ }^{\circ} \mathrm{C} \\
\text { Flow rate }=50 \mathrm{~L} / \mathrm{h} \\
\text { Oxygen concentration }= \\
21 \% \mathrm{O}_{2} \\
\text { Duration }=2,4 \text { days }\end{array}$ & $\begin{array}{l}\text { Mesophilic } \\
\quad \text { (batch) }\end{array}$ & $\begin{array}{l}\text { After } 4 \text { days of aeration, there were } \\
\text { up to 10\% VS losses, as well as a reduction } \\
\text { in VFA, simple sugars, and low-weight } \\
\text { organic molecules. } \\
\text { The bacterial community became } \\
\text { more diverse as a result of the aerobic } \\
\text { circumstances. } \\
\text { Because of the high excretion of } \\
\text { exoenzymes, the Proteobacteria phylum may } \\
\text { have a superior capacity to hydrolyze less } \\
\text { easily biodegradable compounds. }\end{array}$ & \begin{tabular}{|c|} 
The methane potential of \\
pretreatment waste was maintained (500 \\
NLCH4/kg VS), but after a long period of \\
aeration, the methane potential was reduced \\
to the starting amount of waste.
\end{tabular} & $\begin{array}{l}\text { Fisgativa et al. } \\
\text { (2016b) }\end{array}$ \\
\hline $\begin{array}{l}\text { Food waste } \\
\qquad(\text { FW })\end{array}$ & $\begin{array}{c}\text { BIOLOGICAL } \\
\text { Enzymatic pretreatment }\end{array}$ & $\begin{array}{l}\text { Mesophilic (semi- } \\
\text { continuous) }\end{array}$ & $\begin{array}{c}\bullet \quad \text { COD removal rates were } 96.7 \pm \\
1.5 \%, 92.1 \pm 3.4 \%, 88 \pm 2.3 \%, 84.1 \pm 2.3 \% \\
88.4 \pm 3.2 \% \text { when OLRs of } 12,14,16,18, \\
\text { and } 20 \mathrm{~g} \mathrm{COD/Ld} \text { were utilized, respectively. } \\
\bullet \quad \text { The COD removal rate declined } \\
\text { slightly as the OLR increased. }\end{array}$ & \begin{tabular}{|c|} 
The biogas production rate had \\
increased to $5.2 \pm 0.3,5.7 \pm 0.3,6.4 \pm 0.2$, \\
$6.9 \pm 0.2$ and $7.8 \pm 0.1 \mathrm{~L} / \mathrm{L} . \mathrm{d}$ when the OLR \\
was increased from $12 \mathrm{mgCOD} / \mathrm{Ld}$ to 14 \\
16,18 and $20 \mathrm{mgCOD} / \mathrm{L} . \mathrm{d}$, respectively. \\
The resulting methane yields were \\
$0.30,0.28,0.28,0.26,0.27 \mathrm{~m} 3 \mathrm{CH} 4 / \mathrm{kg}$ \\
COD removed, respectively.
\end{tabular} & $\begin{array}{l}\text { Zhang et al. } \\
\text { (2020) }\end{array}$ \\
\hline
\end{tabular}




\begin{tabular}{|c|c|c|c|c|c|}
\hline $\begin{array}{c}\text { Type of } \\
\text { organic waste }\end{array}$ & $\begin{array}{l}\text { Pretreatment } \\
\text { conditions }\end{array}$ & $\begin{array}{c}\text { Type of AD } \\
\text { system }\end{array}$ & Impact of pretreatment & Anaerobic digestion performance & References \\
\hline & & & & \begin{tabular}{|c|} 
\\
typically between $60-64 \%$, showing that \\
the digestion process was stable.
\end{tabular} & \\
\hline $\begin{array}{l}\text { Food waste } \\
\text { (FW) }\end{array}$ & $\begin{array}{l}\text { BIOLOGICAL } \\
\text { Fungal mass }\end{array}$ & $\begin{array}{l}\text { Mesophilic } \\
\quad \text { (batch) }\end{array}$ & \begin{tabular}{|c|} 
about $89.1 \mathrm{~g} / \mathrm{L}$ glucose, $2.4 \mathrm{~g} / \mathrm{L}$ free \\
amino nitrogen and $165 \mathrm{~g} / \mathrm{L}$ SCOD were \\
produced \\
- $\quad \begin{array}{c}\text { preduction in VS within } 24 \\
\text { hours. }\end{array}$ \\
\end{tabular} & \begin{tabular}{|l} 
the methane yield and methane \\
production rate were 2.3 and 3.5 times \\
higher than untreated FW. \\
The percentage of VS of about \\
$80.4 \pm 3.5 \%$ was achieved.
\end{tabular} & $\begin{array}{l}\text { Kiran et al., } \\
\text { (2015) }\end{array}$ \\
\hline $\begin{array}{l}\text { Food waste } \\
\text { (FW) }\end{array}$ & $\begin{array}{c}\text { BIOLOGICAL } \\
\text { Fungal mash } \\
\text { (concentration: } 2 \mathrm{~g} / \mathrm{L} \text { ) }\end{array}$ & $\begin{array}{l}\text { Mesophilic } \\
\quad \text { (batch) }\end{array}$ & \begin{tabular}{|c|} 
- \\
a total of $19.1 \%$ reduction in VS \\
was achieved. \\
the SCOD concentrations increased \\
to $6853.8 \pm 223.7 \mathrm{mg} / \mathrm{L}$ after $24 \mathrm{~h}$ of \\
hydrolysis with the fungal mash, higher than \\
untreated $\mathrm{FW}$. \\
the FAN concentration increased to \\
$74.1 \pm 13.9 \mathrm{mg} / \mathrm{L}$ after 24 hours pretreatment \\
The glucose concentration increased \\
to $3598.8 \pm 128.3 \mathrm{mg} / \mathrm{L}$ after 24 hours \\
pretreatment.
\end{tabular} & 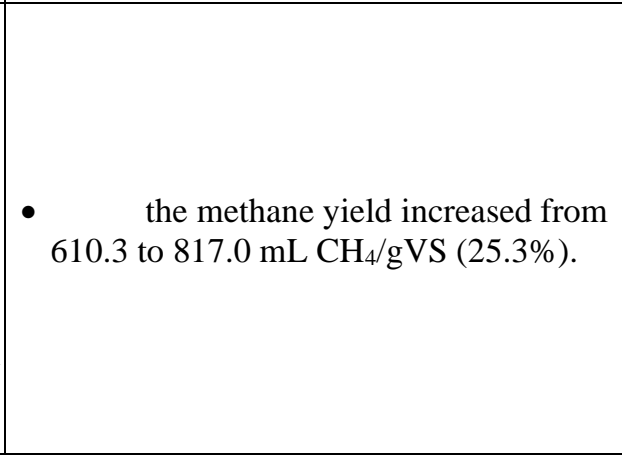 & $\begin{array}{l}\text { Yin et al., } \\
\text { (2016) }\end{array}$ \\
\hline $\begin{array}{l}\text { Kitchen waste } \\
\qquad(\mathrm{KW})\end{array}$ & \begin{tabular}{|c|} 
COMBINATION \\
PRETREATMENT \\
Combined mechanical- \\
ultrasonic pretreatment \\
(CMUP) \\
Mechanical pretreatment \\
(MP): Size reduction \\
using kitchen blender \\
Ultrasonic pretreatment \\
(UP): \\
Frequency $=40 \mathrm{kHz}$ \\
Time $=24 \mathrm{~min}$
\end{tabular} & $\begin{array}{l}\text { Mesophilic } \\
\quad \text { (batch) }\end{array}$ & $\begin{array}{l}\text { The biodegradability of MP } \\
\text { (control) and CMUP is } 72 \% \text { and } 86 \% \text {, } \\
\text { respectively, in both trials. }\end{array}$ & $\begin{array}{l}\text { The control (MP) and CMUP } \\
\text { experiments produced } 382 \mathrm{~mL} \mathrm{CH}_{4} / \mathrm{gVS} \\
\text { and } 493 \mathrm{~mL} \mathrm{CH} 4 / \mathrm{gVS} \text { of methane, } \\
\text { respectively. } \\
\text { This clearly reveals that the CMUP } \\
\text { improves methane generation and } \\
\text { biodegradability, implying that the } \\
\text { hydrolysis and methanogenesis phases of } \\
\text { the process are improved by this combined } \\
\text { pretreatment. }\end{array}$ & $\begin{array}{l}\text { Karouach et al. } \\
\text { (2020) }\end{array}$ \\
\hline
\end{tabular}

APPLIED ECOLOGY AND ENVIRONMENTAL RESEARCH 19(6):4795-4847.

http://www.aloki.hu • ISSN 15891623 (Print) • ISSN 17850037 (Online)

DOI: http://dx.doi.org/10.15666/aeer/1906 47954847

(c) 2021, ALÖKI Kft., Budapest, Hungary 


\begin{tabular}{|c|c|c|c|c|c|}
\hline $\begin{array}{c}\text { Type of } \\
\text { organic waste }\end{array}$ & $\begin{array}{l}\text { Pretreatment } \\
\text { conditions }\end{array}$ & $\begin{array}{c}\text { Type of AD } \\
\text { system }\end{array}$ & Impact of pretreatment & Anaerobic digestion performance & References \\
\hline $\begin{array}{l}\text { Kitchen waste } \\
\qquad(\mathrm{KW})\end{array}$ & $\begin{array}{c}\text { COMBINATION } \\
\text { PRETREATMENT } \\
\text { Microwave-hydrogen } \\
\text { peroxide pretreatment } \\
\\
\mathrm{H}_{2} \mathrm{O}_{2} \text { added }=0.38 \mathrm{~g} / \mathrm{gTS} \\
\text { at } 30 \%(\mathrm{v} / \mathrm{v}) ; \\
\text { Contact time }=1 \mathrm{~h} ; \\
\text { Microwave } \\
\text { frequency }=2450 \mathrm{MHz} \\
\mathrm{T}_{\text {max }}=85^{\circ} \mathrm{C} \\
\text { Ramp time }=40 \mathrm{~min} \\
\text { Retention } \\
\text { time }=1 \mathrm{~min}\end{array}$ & $\begin{array}{l}\text { Mesophilic } \\
\quad \text { (batch) }\end{array}$ & $\begin{array}{c}\text { Pretreatment of kitchen waste (KW) } \\
\text { (from Canadian OFMSW) at } 115^{\circ} \mathrm{C} \text { and } \\
145^{\circ} \mathrm{C} \text { improved biogas production by } 4-7 \% \\
\text { compared to untreated KW (control). } \\
\text { Biogas production was reduced } \\
\text { when pretreated at } 175^{\circ} \mathrm{C} \text { due to the } \\
\text { development of refractory chemicals, which } \\
\text { inhibited digestion. } \\
\text { The effect of pretreatment on } \\
\text { - } \quad \text { cumulative biogas production (CBP) for the } \\
\text { liquid component of } \mathrm{KW} \text { was more obvious } \\
\text { for SWA20 at } 145^{\circ} \mathrm{C} \text {, with a } 26 \% \text { increase in } \\
\text { biogas production after } 8 \text { days of digestion } \\
\text { compared to the control. } \\
\text { - The enhanced substrate availability } \\
\text { in the liquid fraction following MW } \\
\text { pretreatment resulted in a } 78 \% \text { increase in } \\
\text { biogas generation compared to the control. }\end{array}$ & \begin{tabular}{|} 
The combination of $\mathrm{MW}$ and $\mathrm{H}_{2} \mathrm{O}_{2}$ \\
- \\
stabilization or increased biogas generation. \\
All $\mathrm{H}_{2} \mathrm{O}_{2}$-pretreated samples had a \\
considerable lag phase, and the CBP was \\
typically lower than MW irradiated only \\
samples.
\end{tabular} & $\begin{array}{c}\text { Shahriari et al. } \\
\text { (2012) }\end{array}$ \\
\hline $\begin{array}{l}\text { Food waste } \\
\text { (FW) }\end{array}$ & $\begin{array}{c}\text { COMBINATION } \\
\text { PRETREATMENT } \\
\text { Ultrasonic with acid } \\
\text { (UA) } \\
\text { (SE }=79 \mathrm{~kJ} / \mathrm{kg} \mathrm{TS}, \mathrm{pH} 3 \\
\text { with } 1 \mathrm{~N} \mathrm{HCl}, 24 \mathrm{~h}) . \\
\\
\text { Ultrasonic with base } \\
\text { (UB) } \\
\mathrm{SE}=79 \mathrm{~kJ} / \mathrm{kg} \mathrm{TS}, \mathrm{pH} 11 \\
\text { with } \mathrm{NaOH}, 24 \mathrm{~h}) .\end{array}$ & $\begin{array}{l}\text { Mesophilic } \\
\text { (batch) }\end{array}$ & $\begin{array}{l}\text { UB preatreatment showed the } \\
\text { highest increase in soluble COD and soluble } \\
\text { protein by } 33 \% \text { and } 40 \% \text {, respectively. } \\
\text { the highest increase in soluble } \\
\text { carbohydrate by } 31 \% \text { was indicated by UA } \\
\text { pretreatment. }\end{array}$ & \begin{tabular}{|l} 
UA pretreatment achieved the \\
highest hydrogen yield of $118 \mathrm{~mL} / \mathrm{g} \mathrm{VS}$ initial. \\
$\bullet \quad$ UB pretreatment produced a \\
hydrogen yield of $67 \mathrm{~mL} / \mathrm{g} \mathrm{VS}$ initial which \\
was slightly higher than that was observed \\
in untreated FW (42 mL/g VS initial $_{\text {. }}$.
\end{tabular} & $\begin{array}{c}\text { Elbeshbishy et } \\
\text { al., (2011) }\end{array}$ \\
\hline
\end{tabular}




\begin{tabular}{|c|c|c|c|c|c|}
\hline $\begin{array}{c}\text { Type of } \\
\text { organic waste }\end{array}$ & $\begin{array}{l}\text { Pretreatment } \\
\text { conditions }\end{array}$ & $\begin{array}{c}\text { Type of AD } \\
\text { system }\end{array}$ & Impact of pretreatment & Anaerobic digestion performance & References \\
\hline $\begin{array}{l}\text { Kitchen waste } \\
\text { (from } \\
\text { OFMSW) }\end{array}$ & \begin{tabular}{|c|} 
COMBINATION \\
PRETREATMENT \\
Thermo-acid \\
pretreatment \\
$1.12 \% \mathrm{HCl}$ for 94 min or \\
$1017 \% \mathrm{HCl}$ for $86 \mathrm{~min}$ \\
Temperature $=100^{\circ} \mathrm{C}$
\end{tabular} & & $\begin{array}{c}\text { Chemical pretreatment of KW using } \\
\text { either } 1.12 \% \mathrm{HCl} \text { for } 94 \text { minutes or } 1.17 \% \\
\mathrm{HCl} \text { for } 86 \text { minutes (at } 100^{\circ} \mathrm{C} \text { ) raised soluble } \\
\text { sugars concentration by } 120 \% \text { compared to } \\
\text { untreated } \mathrm{KW} \text {. }\end{array}$ & $\begin{array}{l}\text { The mono-sugars glucose and } \\
\text { fructose were primarily responsible for the } \\
\text { rise in soluble sugars. }\end{array}$ & $\begin{array}{c}\text { Vavouraki et al. } \\
\text { (2013) }\end{array}$ \\
\hline
\end{tabular}


In addition, longer contact time requirements (at least 24 hours) cause this pretreatment method is not appropriate to be performed on a full scale even though the batch test indicates high methane production (Braguglia et al., 2018). In addition to numerous modes of action depending on distinct FW components, Ma et al. (2018) showed that enzymatic pretreatment may be used quickly and effectively in FW hydrolysis. Amylase, protease, and lipase are enzymes that may break down macromolecular starches, proteins, and lipids into glucose, free amino acids (FAN), and long-chain fatty acids (LCFA), correspondingly. Despite the fact that enzymatic pretreatment of FW resulted in highefficiency hydrolysis with a VSS removal rate of $60 \%$ and a methane yield and generation rate roughly double that of the control, it is still not extensively used in $\mathrm{AD}$ processes due to the high cost of commercial enzymes. Biological pretreatment methods of food waste consisting of microbial reactions, enzyme reactions, and aeration have been investigated by several researchers such as Kiran et al. (2015), Yin et al. (2016), Fisgativa et al. (2016b), and Zhang et al. (2020).

The combination of various pretreatment methods involves the utilization of more than one pretreatment method in which the combined effect produces better substrate solubilization which in turn produces higher biogas production and faster AD kinetic processes (Ariunbaatar et al., 2014; Salihu and Alam, 2016). Combination pretreatment can reduce inhibition, formation of recalcitrant products, long retention time, enzyme specialization as well as energy costs. Combination pretreatment is also used when a single pretreatment is insufficient to achieve the desired outcome due to its unique mechanism of action (Braguglia et al., 2018). There are two major combinations of pretreatment methods, namely thermo-chemical pretreatment and thermo-mechanical pretreatment. Thermo-chemical pretreatment is a combination of two methods, namely thermal pretreatment and chemical pretreatment. The chemicals that are commonly added to these pretreatment combinations are sodium hydroxide $(\mathrm{NaOH})$, calcium oxide $(\mathrm{CaO})$, or lime and hydrogen peroxide $\left(\mathrm{H}_{2} \mathrm{O}_{2}\right)$. Several studies have been conducted and reported regarding the thermo-chemical pretreatment method to improve the anaerobic biodegradability of organic wastes such as sludge (Tong et al., 2018), animal manure (Khan and Ahring, 2021), organic fraction of municipal solid waste (OFMSW) (Bala et al., 2019), and FW (Junoh et al., 2015). Thermo-mechanical pretreatment is a combination of two methods: thermal and mechanical pretreatment. Combination of microwave-ultrasonic and thermo-pressure pretreatment are the two methods that are available under the thermo-mechanical pretreatment. Most studies involving thermomechanical pretreatment are performed on sludge. In addition, there is a combination of other pretreatment methods that are also used to pretreat the organic waste i.e physicalchemical pretreatment (ultrasonic-alkaline, ultrasonic-acid) and electro-chemical pretreatment. Table 5 demonstrates the summary for some of the pretreatment studies involving mechanical, chemical, thermal, biological, and combination of various pretreatment methods reported on FW.

\section{Inoculum and microbial communities in AD of FW}

The AD of FW is a complicated process. Numerous inhibitors, such as ammonia buildup and VFAs, cause poor performance and then even system malfunction (Dai et al., 2013; Agyeman and Tao, 2014; Owamah and Izinyon, 2015). The digesters are typically run at a low organic loading rate (OLR) to ensure a steady operation (Tampio et al., 2014). The majority of prior studies focused on process monitoring and control to increase 
process stability and efficiency (Li et al., 2014). AD is a multi-stage biochemical process that involves complex organic molecules going through hydrolysis, acidogenesis, acetogenesis, and methanogenesis in order. In the process of producing methane by AD of FW, the microbial communities differ at different stages of hydrolysis and acidification, hydrogen synthesis, and methane production (Wang et al., 2018). Because $\mathrm{AD}$ is a biochemical process involving a wide range of microbial groups, microorganisms form the foundation of the digesters. Bacteria and archaea are the two types of microorganisms that participate in anaerobic digestion. Bacteria degrade complicated substrates to produce VFA, $\mathrm{CO}_{2}$, and $\mathrm{H}_{2}$, while archaea produce methane (Ren et al., 2018). Seon et al. (2014) and Yamada et al. (2006) pointed out that Clostridium, Bacteroides, Bifidobacterium, Butyrivibrio, Proteobacteria, Pseudomonas, Bacillus, Streptococcus, Eubacterium, and other bacteria are involved in the hydrolysis and acidogenesis processes. Methanogens are archaea, and there have been 65 species discovered so far, divided into 3 orders, 7 families, and 19 genera. Imachi et al. (2007), Nielsen et al. (2007), and Sousa et al. (2007) reveal that the primary bacteria that produce methane include Methanobacterium, Methanococcus, Methanobrevibacter, Methanomicrobium, Methanosarcina, and Methanosaeta.

To enhance the AD of organic waste, inoculum has been employed as a microbial booster. Fresh manure and anaerobically digested sludge from numerous wastewater treatment plants (WTPs) and manure treatment AD plants are typical inoculum sources, as the bacteria are more acclimated to anaerobic environments (Bong et al., 2017). According to $\mathrm{Gu}$ et al. (2014), some organic waste cannot be digested on its own, necessitating the use of additional methane-producing bacteria to commence the digestion process. Active microbial communities are required for anaerobic digestion, and inoculums should contain these communities. A good inoculum can speed up digestion, boost biogas production, reduce startup time, and make the digestion process more stable (Gu et al, 2014). Many trace elements could be found in the inoculum, which could aid in the activity of anaerobic microbes. Sufficient trace elements in the seeded inoculum, such as $\mathrm{Ni}$ and Mo, could have a good impact on the AD of FW, enhancing methane production and hydrolysis rate while also decreasing the lag phase (Sawatdeenarunat et al., 2021). The majority of studies examining the impacts of different inoculums in biomass digestion have concentrated on substrate breakdown and biogas production, rather than the inoculums themselves, such as enzyme activity and nutrient content. Inoculum micronutrients can boost enzyme activity and biogas output (Zhang et al., 2011).

The use of inoculum from various sources in the mono-digestion of FW has been practiced by several researchers such as Lim et al. (2020), Zhang et al. (2017), Wu et al. (2016), Li et al. (2015), Jang et al. (2015) and many more. Lim et al. (2020) compared two techniques of converting mesophilic to thermophilic consortia and evaluated the effect of inoculum on the start-up of thermophilic anaerobic digestion (AD) of FW. The use of inoculum was crucial during the start-up process, and a one-step temperature increase was the favored method. The inoculum employed in their investigation came from two places: anaerobic sludge obtained from a digester treating activated sludge from a wastewater reclamation plant in Singapore and anaerobic sludge taken from a laboratory pilot-scale $1000 \mathrm{~L}$ digester treating $\mathrm{FW}$ for more than three months at $35^{\circ} \mathrm{C}$. When the temperature approached $50{ }^{\circ} \mathrm{C}$, there were symptoms of instability and failure, according to observations made during the investigation. For step-wise temperature increase reactors, a large increase in absolute abundance of bacteria but a decrease in archaea likely 
resulted in an excess of $\mathrm{AD}$ intermediates that were not digested by methanogens in time, generating reactor sourness. At this point, there will be an accumulation of VFA as well as an initial decrease in biogas. However, the one-step temperature increase reactor recovered from VFA accumulation and poor biogas generation after 10 days attributed to the successful adaptation of thermophilic bacteria such as Thermotogae, Thermoanaerobacterales, and Thermoanaerobacterium, as well as Methanosarcina. Microbial consortia for thermophilic AD were successfully generated using the one-step temperature increase technique and a suitable inoculum, which assisted the start-up of thermophilic AD of FW. Zhang et al. (2017) evaluated the efficacy of a three-stage anaerobic digester (TSAD) in treating $\mathrm{FW}$, as well as the synergistic effect of microorganisms in the TSAD. The inoculum employed in this investigation was wasteactivated sludge (WAS) from a large-scale anaerobic digester at Singapore's Ulu Pandan Water Reclamation Plant (UPWRP). TSAD exhibited a 24-54\% higher methane yield at a high organic loading rate of $10 \mathrm{~g}$ VS/L when compared to standard one-stage and twostage anaerobic digesters. TSAD also obtained a greater volatile solid reduction rate of $83.5 \pm 1.3 \%$. When the one-stage and two-stage digesters had already soured and failed, TSAD showed a strong buffering ability even at high organic loading. According to the pyrosequencing study, the bacterial community in TSAD is more diversified than in control digesters. Multi-function methanogens like Methanosarcina, as well as some dominant populations with acetogenesis, amino-acid consumption, and symbiotic functions, have been discovered to selectively enrich TSAD. Wu et al. (2016) used highthroughput sequencing of $16 \mathrm{~S}$ rRNA genes to investigate the microbial community during the start-up stage of a thermophilic AD treating FW with sludge sourced from secondary sedimentation basin from the Jinhai Municipal Wastewater Treatment Plant in Chengdu. They discovered that thermophilic AD that treated FW could be started up fast and successfully. At the end of the start-up, bacterial groups involved in hydrolysis, fermentation, acetogenesis, and syntrophic oxidation were dominating, and a steady hydrogenotrophic/acetoclastic methanogen ratio was critical for methanogenesis. These modifications represented microbial communities' adaptation to AD environments in enhancing AD performance. The fast start-up of the AD process was likely aided by the cooperation of bacterial and methanogenic populations, as well as the thermophilic environment. During the start-up phase of this study, many thermophilic Firmicutes, Bacteroidetes, and Thermotogae with hydrolytic, acidogenic, and acetogenic activities became predominant. Li et al. (2015) utilized organic loading rate (OLR) disturbances in a mesophilic anaerobic digester to produce stable and deteriorative phases in FW inoculated with anaerobic sludge collected from a rural household biogas digester operated at ambient temperature. 454-pyrosequencing was used to look at the microbial community of each phase. At the deteriorative phase, the relative abundance of acidproducing bacteria and syntrophic volatile fatty acid (VFA) oxidizers grew considerably, but the dominant methanogens (Methanosaeta) remained acetoclastic. The mismatch between bacteria and methanogens could be contributing to the deterioration of the process.

One of the most important drivers of anaerobic bioconversion of various feedstocks in $\mathrm{AD}$ processes is the $\mathrm{AD}$ microbial community. As various microorganisms are regularly introduced through co-feedstocks, co-digestion systems tend to support microbial communities with greater variety than mono-digestion systems (Karki et al., 2021). Codigestion of FW with other organic substrates is gaining popularity because it improves $\mathrm{AD}$ efficiency, increases biogas generation, and enhances microorganism synergy 
(Braguglia et al., 2018). Firmicutes, Chloroflexi, Bacteroidetes, Proteobacteria, and Actinobacteria are the most common bacteria found in traditional AD (Dai et al., 2016; Zamanzadeh et al., 2017). The type of feedstock has a significant impact on the structure of microbial communities. Animal dungs and sewage sludge are the most common organic waste streams explored for co-digesting FW for biogas production. Firmicutes (40.8\%), Bacteroidetes (23.9\%), Proteobacteria (5.9\%), and Chloroflexi (1.1\%) constitute the composition of bacterial communities found in sewage sludge-fed AD systems, while the percentage of bacterial communities consisting of Chloroflexi (52.9\%), Firmicutes (20.6\%), Bacteroidetes (6.6\%), and Proteobacteria $(6.3 \%)$ are found in manure-fed reactor systems (Dai et al., 2016). The microbial community structure is also influenced by the ratio of different feedstocks and their biodegradability (Karki et al., 2021).

Co-digestion of FW with other substrates such as animal manure and sewage sludge has been practiced by several researchers such as Muratcobanoglu et al. (2020), Chan et al. (2019), Kim et al. (2019), Wang et al. (2020), Lim et al. (2013) and many more. Muratcobanoglu et al. (2020) used batch tests in mesophilic conditions to explore the effects of graphite on the anaerobic digestion of food waste (FW), cow dung (CM), and their mixture (FW/CM). Graphite was employed as a conductive material in the anaerobic digestion of $\mathrm{CW}, \mathrm{FW}$, and the mixture of $\mathrm{FW}+\mathrm{CW}$ in their investigation. Carbon allotrope graphite has a huge surface area and a strong conductivity. The maximum biogas generation with graphite addition is $1128.46,829.6$, and $1471.1 \mathrm{~mL} / \mathrm{gVS}$ for FW $+1 \mathrm{~g} / \mathrm{L}$, $\mathrm{CM}+1.5 \mathrm{~g} / \mathrm{L}$, and FW/CM $+0.75 \mathrm{~g} / \mathrm{L}$, respectively. Muratcobanoglu and his co-workers also studied the relationship between microbial community structure and biogas production when graphite is added. They found that Aminiphilus (13-14\%), Actinobaculum (13-15\%), and Clostridium (12-18\%) were the most common bacterial genera in graphite-added FW, CM, and FW/CM reactors, according to $16 \mathrm{~S}$ rRNA gene amplicon sequencing results. In this anaerobic digestion configuration, abundances of Clostridium along with co-digestion impact FW/CM biogas generation synergistically. In the graphite-added digesters, Methanosaeta was the most common methanogen; however, the relative abundance of these groups differed. Chan et al. (2019) supplemented copper (such as $\mathrm{CuSO}_{4}$ and $\mathrm{CuCl}_{2}$ ) at 10,30 , and $50 \mathrm{mg} / \mathrm{L} \mathrm{Cu}{ }^{2+}$ to boost anaerobic co-digestion of food waste and domestic wastewater. They reported that copper supplementation enhanced high methane production $\left(0.260-0.325 \mathrm{~L} \mathrm{CH}_{4} / \mathrm{g} \mathrm{COD}_{\text {removed }}\right)$ compared to control $\left(0.175 \mathrm{~L} \mathrm{CH}_{4} / \mathrm{g} \mathrm{COD}_{\text {removed }}\right)$, in addition to a COD removal efficiency of more than $90 \%$. When $10 \mathrm{mg} / \mathrm{L}$ of $\mathrm{Cu}^{2+}$ was added to the mixture, the cumulative methane production increased by $94.1 \%$. They also found that copper as a cofactor of several microbial enzymes and coenzymes involved in methane synthesis enhanced methane production as well as COD removal efficiency. However, microbial community analysis confirmed that copper supplementation had a considerable impact on bacterial populations, but only a little impact on archaea diversity. When compared to the control, there was a significant change in the microbial populations following copper supplementation. Bacteroidetes $(37.2 \%)$ were the most common phylum followed by Firmicutes (20.7\%), Thermotogae (17.3\%), and Synergistetes (6.9\%) after copper supplementation. Kim et al. (2019) investigated the impact of food waste (FW) codigestion with wastewater biosolids (WWB) on microbial communities by running thirteen lab-scale digesters for 100 days under various operational conditions, including OLR ( 2 and $4 \mathrm{~kg} \mathrm{COD} / \mathrm{m}^{3}$.day), feed types (WWB and FW), and FW content (10\%, 90\%, $100 \%)$. FW co-digestion increased biogas generation by $13 \%$ and COD degradation rates 
by up to $101 \%$ when compared to mono-digestion of WWB. From the microbial analysis, Syntrophomonas was the dominating genus among fermentative bacteria/acetogens in FW digesters, whereas Clostridium was prominent in WWB digesters. Methanosarcina and Methanosaeta are the dominant methanogens in FW digesters and WWB digesters, respectively. The Bacteroidetes population was shown to be highly associated with COD breakdown rates and methane production. Clostridium was shown to be highly associated with methane production rate in FW digesters, syntrophs in WWB digesters, and acetoclastic methanogens in both digesters. Wang et al. (2020) investigated the methane output from the digesters that co-digest pig manure (PM) and food waste (FW) at various TS concentrations (R1, TS 5\%; R2, TS 10\%; R3, TS 15\%; and R4, TS 20\%). They reported that the increase in TS concentrations from 5\% to $15 \%$ did not have a significant effect on specific methane yield (278.8-291.7 NmL/g VS added) and even decreased (259.8 NmL/g VS added) when TS concentration was increased to $20 \% \mathrm{TS}$. There was a general shifting from the acetoclastic pathway to the mixotrophic pathway and hydrogenotrophic pathway in dry AD (20\% TS), with mixotrophic and hydrogenotrophic methanogens predominant. Firmicutes, Proteobacteria, and Chloroflexi were the most prevalent bacteria in the samples. Firmicutes, Proteobacteria, and Chloroflexi all had relative abundances of $33.9 \%, 19.5 \%$, and $11.4 \%$, respectively, within the mixture. Lim et al. (2013) examined the microbial community and reactor performance in single and two-phase continuously stirred tank reactors (CSTRs) for the anaerobic co-digestion of brown water and food waste. After 150 days of reactor operation, the bacterial and archaeal populations were investigated. Methane generation in two-phase CSTR was found to be $23 \%$ greater than in single-phase CSTR. The abundance of Firmicutes and increased bacterial variety in two-phase CSTR, and the scarcity of Firmicutes in singlephase CSTR, might explain these observations. Both CSTRs had high amounts of Methanosaeta, which was associated with low acetate levels in their effluent.

\section{Conclusions}

To be known as substrate containing high organic matter and high moisture content as well as the highest contributor in the MSW composition, FW has enormous potential and is one of the most promising substrates to produce biogas and methane using biological treatment method, i.e. anaerobic digestion (AD). The concept of waste recovery is important in the present context in order to reduce waste and produce renewable energy due to the abundance of FW. This review shows the progress and changes in the field of research related to FW conversion to energy. From the reviews conducted, FW is a complicated substrate with different degrees of decomposability. The success of the biodegradation process also depends on several parameters such as temperature, $\mathrm{pH}$ and alkalinity, mixing strategy, hydraulic retention time (HRT) and organic loading rate (OLR). As a result, the biogas produced through the AD process can vary significantly when FW is processed either by batch, continuous or semi-continuous method. In FWrelated research studies, pretreatment and co-digestion are among the issues that have been frequently highlighted over the last 20 years. The implementation of pretreatment can improve the degree of anaerobic biodegradability of FW which in turn increases the production of biogas and methane yield. Pretreatment technology is introduced in AD of FW aims to improve the solubilization of organic matter and reduces the size of organic compounds before decomposed by anaerobic bacteria, enhance the hydrolysis rate and improve the biodegradability of organic matter to support a more efficient hydrolysis 
process. However, adverse effects such as VFA accumulation during the hydrolysis stage may interfere in the AD process due to excessive pretreatment. Co-digestion of FW with organic substrates such as green waste or agricultural waste, sewage sludge and animal manures is getting more attention in the research field related to AD of FW. This strategy succeeded in increasing the number of major nutrients, stabilizing the digestate produced and increasing the biogas and methane production. Although many studies on AD of FW produced encouraging findings regarding the advances in the design and optimization process, but further studies related to cost savings in the construction of bioreactor and monitoring processes still need to be implemented.

Acknowledgment. The authors would like to thank Universiti Sains Malaysia for the financial support through USM Short Term Grant (304/PAWAM/60313043) and technical support to complete this study.

\section{REFERENCES}

[1] Abd Ghafar, S. W. (2017): Food waste in Malaysia: Trends, current practices and key challenges. - FFTC-AP 19582: 1-12.

[2] Agbalakwe, E. (2011): Anaerobic treatment of glycol contaminated wastewater for methane production. - Master Thesis, University of Stavanger, Retrieved from https://uis.brage.unit.no/uisxmlui/bitstream/handle/11250/182464/Agbalakwe\%2c

Ekene.pdf.

[3] Agyeman, F. O., Tao, W. (2014): Anaerobic co-digestion of food waste and dairy manure: effects of food waste particle size and organic loading rate. - Journal of Environmental Management 133: 268-274.

[4] Akgul, D., Cella, M. A., Eskicioglu, C. (2017): Influences of low-energy input microwave and ultrasonic pretreatments on single-stage and temperature-phased anaerobic digestion (TPAD) of municipal wastewater sludge. - Energy 123: 271-282.

[5] Algapani, D. E., Wang, J., Qiao, W., Su, M., Goglio, A., Wandera, S. M., Jiang, M., Pan, X., Adani, F., Dong, R. (2017): Improving methane production and anaerobic digestion stability of food waste by extracting lipids and mixing it with sewage sludge. - Bioresource Technology 244: 996-1005.

[6] Angelidaki, I., Ahring, B. K. (2000): Methods for increasing the biogas potential from the recalcitrant organic matter contained in manure. - Water Science and Technology 41(3): 189-194.

[7] Anggarini, S., Hidayat, N., Sunyoto, N. M. S., Wulandari, P. S. (2015): Optimization of hydraulic retention time (HRT) and inoculums addition in wastewater treatment using anaerobic digestion system. - Agriculture and Agricultural Science Procedia 3: 95-101.

[8] Appels, L., Baeyens, J., Degreve, J., Dewil, R. (2008): Principles and potential of the anaerobic digestion of waste-activated sludge. - Progress in Energy and Combustion Science 34: 755-781.

[9] Appels, L., Assche, A. V., Willems, K., Degrève, J., Impe, J. V., Dewil, R. (2011): Peracetic acid oxidation as an alternative pre-treatment for the anaerobic digestion of waste activated sludge. - Bioresource Technology 102: 4124-4130.

[10] Ariunbaatar, J., Panico, A., Esposito, G., Pirozzi, F., Lens, P. N. L. (2014): Pretreatment methods to enhance anaerobic digestion of organic solid waste. - Applied Energy 123: 143156.

[11] Ariunbaatar, J., Di Perta, E. S., Panico, A., Frunzo, L., Esposito, G., Lens, P. N. L., Pirozzi, F. (2015a): Effect of ammoniacal nitrogen on one-stage and two-stage anaerobic digestion of food waste. - Waste Management 38: 388-398. 
[12] Ariunbaatar, J., Panico, A., Yeh, D. H., Pirozzi, F., Lens, P. N. L., Esposito, G. (2015b): Enhanced mesophilic anaerobic digestion of food waste by thermal pretreatment: substrate versus digestate heating. - Waste Management 46: 176-181.

[13] Arsova, L. (2010): Anaerobic digestion of food waste: Current status, problems and an alternative product. - Master Thesis, Columbia University.

[14] Bala, R., Gautam, V., Mondal, M. K. (2019): Improved biogas yield from organic fraction of municipal solid waste as preliminary step for fuel cell technology and hydrogen generation. - International Journal of Hydrogen Energy 44(1): 164-173.

[15] Banu, J. R., Merrylin, J., Mohamed Usman, T. M., Yukesh Kannah, R., Gunasekaran, M., Kim, S. H., Kumar, G. (2020): Impact of pretreatment on food waste for biohydrogen production: A review. - International Journal of Hydrogen Energy 45: 18211-18225.

[16] Bazargan, A., Bazargan, M., McKay, G. (2015): Optimization of rice husk pretreatment for energy production. - Renewable Energy 77: 512-520.

[17] Beevi, B. S., Madhu, G., Sahoo, D. K. (2015): Performance and kinetic study of semi-dry thermophilic anaerobic digestion of organic fraction of municipal solid waste. - Waste Management 36: 93-97.

[18] Bharathirajaa, B., Sudharsana, T., Jayamuthunagai, J., Praveenkumar, R., Chozhavendhan, S., Iyyappan, J. (2018): Biogas production - A review on composition, fuel properties, feed stock, and principles of anaerobic digestion. - Renewable and Sustainable Energy Reviews 90: 570-582.

[19] Bhatia, P., Fujiwara, M., Salangsang, M. C. D., Qian, J., Liu, X., Ban, S., Myojin, M., Toda, T. (2021): Effect of semi-continuous anaerobic digestion on the substrate solubilisation of lignin-rich steam-exploded Ludwigia grandiflora. - Applied Sciences 11: 4452.

[20] Bong, C. P. C., Lee, C. T., Ho, W. S., Hashim, H., Klemesc, J. J., Ho, C. S. (2017): Minireview on substrate and inoculum loadings for anaerobic co-digestion of food waste. Chemical Engineering Transactions 56: 493-498.

[21] Borowski, S. (2015): Temperature-phased anaerobic digestion of the hydromechanically separated organic fraction of municipal solid waste with sewage sludge. - International Biodeterioration and Biodegradation 105: 106-113.

[22] Braguglia, C. M., Gallipoli, A., Gianico, A., Pagliaccia, P. (2018): Anaerobic bioconversion of food waste into energy: A critical review. - Bioresource Technology 248: 37-56.

[23] Browne, J. D., Murphy, J. D. (2013): Assessment of the resource associated with biomethane from food waste. - Applied Energy 104: 170-177.

[24] Capson-Tojo, G., Rouez, M., Crest, M., Steyer, J.-P., Delgenès, J.-P., Escudié, R. (2016): Food waste valorization via anaerobic processes: A review. - Reviews in Environmental Science and Bio/Technology 15(3): 499-547.

[25] Carrere, H., Antonopoulou, G., Affes, R., Passos, F., Battimelli, A., Lyberatos, G., Ferrer, I. (2016): Review of feedstock pretreatment strategies for improved anaerobic digestion: from lab-scale research to full-scale application. - Bioresource Technology 199: 386-397.

[26] Castrillon, L., Maranon, E., Fernandez-Nava, Y., Ormaechea, P., Quiroga, G. (2013): Thermophilic co-digestion of cattle manure and food waste supplemented with crude glycerin in induced bed reactor (IBR). - Bioresource Technology 136: 73-77.

[27] Cavinato, C., Bolzonella, D., Pavan, P., Fatone, F., Cecchi, F. (2013): Mesophilic and thermophilic anaerobic co-digestion of waste activated sludge and source sorted biowaste in pilot-and full-scale reactors. - Renewable Energy 55: 260-265.

[28] Chan, P. C., Lu, Q., de Toledo, R. A., Gu, J. D., Shima, H. (2019): Improved anaerobic codigestion of food waste and domestic wastewater by copper supplementation - Microbial community change and enhanced effluent quality. - Science of the Total Environment 670: 337-344.

[29] Charalambous, P., Vyrides, I. (2021): In situ biogas upgrading and enhancement of anaerobic digestion of cheese whey by addition of scrap or powder zero-valent iron (ZVI). - Journal of Environmental Management 280: 111651. 
[30] Cheerawit, R., Thunwadee, T. S., Duangporn, K., Tanawat, R., Wichuda, K. (2012): Biogas production from co-digestion of domestic wastewater and food waste. - Health and the Environment Journal 3(2): 1-9.

[31] Chen, X., Yan, W., Sheng, K., Sanati, M. (2014): Comparison of high solids to liquid anaerobic co-digestion of food waste and green waste. - Bioresource Technology 154: 215221.

[32] Chen, S., Tao, Z., Yao, F., Wu, B., He, L., Hou, K., Pi, Z., Fu, J.,Yin, H., Huang, Q., Liu, Y., Wang, D., Li, X., Yang, Q. (2020): Enhanced anaerobic co-digestion of waste activated sludge and food waste by sulfidated microscale zerovalent iron: Insights indirect interspecies electron transfer mechanism. - Bioresource Technology 316: 123901.

[33] Choi, J. H., Jang, S. K., Kim, J. H., Park, S. Y., Kim, J. C., Jeong, H., Kim, H. Y., Choi, I. G. (2019): Simultaneous production of glucose, furfural, and ethanol organosolv lignin for total utilization of high recalcitrant biomass by organosolv pretreatment. - Renewable Energy 130: 952-960.

[34] Chu, C. F., Xu, K. Q., Li, Y. Y., Inamori, Y. (2012): Hydrogen and methane potential based on the nature of food waste materials in a two-stage thermophilic fermentation process. International Journal of Hydrogen Energy 37(14): 10611-10618.

[35] Chuenchart, W., Logan, M., Leelayouthayotin, C., Visvanathan, C. (2020): Enhancement of food waste thermophilic anaerobic digestion through synergistic effect with chicken manure. - Biomass and Bioenergy 136: 105541.

[36] Dai, X., Duan, N., Dong, B., Dai, L. (2013): High-solids anaerobic co-digestion of sewage sludge and food waste in comparison with mono digestions: Stability and performance.Waste Management 33(2): 308-316.

[37] Dai, X., Chen, Y., Zhang, D., Yi, J. (2016): High-solid anaerobic co-digestion of sewage sludge and cattle manure: the effects of volatile solid ratio and pH. - Scientific Reports 6: 4-13.

[38] Deepanraj, B., Sivasubramanian, B., Jayaraj, S. (2017): Effect of substrate pretreatment on biogas production through anaerobic digestion of food waste. - International Journal of Hydrogen Energy 42(42): 26522-26528.

[39] Derman, E., Abdulla, R., Marbawi, H., Sabullah, M. K. (2018): Oil palm empty fruit bunches as a promising feedstock for bioethanol production in Malaysia. - Renewable Energy 129: 285-298.

[40] Dhamodharan, K., Kumar, V., Kalamdhad, A. S. (2015): Effect of different livestock dungs as inoculum on food waste anaerobic digestion and its kinetics. - Bioresource Technology 180: 237-241.

[41] Dhar, H., Kumar, P., Kumar, S., Mukherjee, S., Vaidya, A. N. (2016): Effect of organic loading rate during anaerobic digestion of municipal solid waste. - Bioresource Technology 217: 56-61.

[42] Drennan, M. F., Di Stefano, T. D. (2014): High solids co-digestion of food and landscape waste and the potential for ammonia toxicity. - Waste Management 34: 1289-1298.

[43] Elbeshbishy, E., Hafez, H., Dhar, B. R., Nakhla, G. (2011): Single and combined effect of various pretreatment methods for biohydrogen production from food waste. - International Journal of Hydrogen Energy 36(17): 11379-11387.

[44] Esposito, G., Frunzo, L., Giordano, A., Liotta, F., Panico, A., Pirozzi, F. (2012): Anaerobic co-digestion of organic wastes. - Reviews in Environmental Science and Bio/Technology 11(4): 325-341.

[45] Facchin, V., Cavinato, C., Fatone, F., Pavan, P., Cecchi, F., Bolzonella, D. (2013): Effect of trace element supplementation on the mesophilic anaerobic digestion of food waste in batch trials: the influence of inoculum origin. - Biochemical Engineering Journal 70: 7177.

[46] Fernandez-Rodriguez, J., Perez, M., Romero, L. I. (2013): Comparison of mesophilic and thermophilic dry anaerobic digestion of OFMSW: kinetic analysis. - Chemical Engineering Journal 232: 59-64. 
[47] Fisgativa, H., Tremier, A., Dabert, P. (2016a): Characterizing the variability of food waste quality: a need for efficient valorization through anaerobic digestion. - Waste Management 50: 264-274.

[48] Fisgativa, H., Saoudi, M., Tremier, A. (2016b): Impact of an aerobic pretreatment on anaerobic biodegradability of food waste. $-6^{\text {th }}$ international Conference on Engineering for Waste and biomass Valorization, May 23-26 2016, Albi, France.

[49] Forgacs, G. (2012): Biogas production from citrus wastes and chicken feather: pretreatment and co-digestion. - PhD Tesis. Chalmers University of Technology, Sweden.

[50] Franco, R. T., Buffiere, P., Bayard, R. (2018): Co-ensiling of cattle manure before biogas production: effects of fermentation stimulants and inhibitors on biomass and methane preservation. - Renewable Energy 121: 315-323.

[51] Fuess, L. T., Klein, B. C., Chagas, M. F., Rezende, M. C. A. F., Garcia, M. L., Bonomi, A., Zaiat, M. (2018): Diversifying the technological strategies for recovering bioenergy from the two-phase anaerobic digestion of sugarcane vinasse: an integrated techno-economic and environmental approach. - Renewable Energy 122: 674-687.

[52] Gadhe, A., Sonawane, S. S., Varma, M. N. (2014): Ultrasonic pretreatment for an enhancement of biohydrogen production from complex food waste. - International Journal of Hydrogen Energy 39(15): 7721-7729.

[53] Garrone, P., Melacini, M., Perego, A. (2014): Opening the black box of food waste reduction. - Journal of Food Policy 46: 129-139.

[54] Gaur, R. Z., Suthar, S. (2017): Anaerobic digestion of activated sludge, anaerobic granular sludge, and cow dung with food waste for enhanced methane production. - Journal of Cleaner Production 164: 557-566.

[55] Gianico, A., Braguglia, C. M., Mescia, D., Mininni, G. (2013): Ultrasonic and thermal pretreatments to enhance the anaerobic bioconversion of olive husks. - Bioresource Technology 147: 623-626.

[56] Gnaoui, Y. E., Karouach, F., Bakraoui, M., Barzb, M., Bari, H. E. (2020): Mesophilic anaerobic digestion of food waste: Effect of thermal pretreatment on improvement of anaerobic digestion process. - Energy Reports 6: 417-422.

[57] Gou, C., Yang, Z., Huang, J., Wang, H., Xu, H., Wang, L. (2014): Effects of temperature and organic loading rate on the performance and microbial community of anaerobic codigestion of waste activated sludge and food waste. - Chemosphere 105: 146-151.

[58] Grimberg, S. J., Hilderbrandt, D., Kinnunen, M., Rogers, S. (2015): Anaerobic digestion of food waste through the operation of a mesophilic two-phase pilot scale digester assessment of variable loadings on system performance. - Bioresource Technology 178: 226-229.

[59] Gu, Y., Chen, X., Liu, X., Zhou, X., Zhang, Y. (2014): Effect of inoculum sources on the anaerobic digestion of rice straw. - Bioresource Technology 158: 149-155.

[60] Guo, J., Wang, W., Liu, X., Lian, S., Zheng, L. (2014): Effects of thermal pre-treatment on anaerobic co-digestion of municipal biowastes at high organic loading rate. - Chemosphere 101: 66-70.

[61] Gupta, P., Singh, R. S., Sachan, A., Vidyarthi, A. S., Gupta, A. (2012): A re-appraisal on intensification of biogas production. - Renewable Sustainable Energy Reviews 16: 49084916.

[62] Hamdi Muratçobanoglu, H., Gokceka, O. B., Merta, R. A., Zanb, R., Demirel, S. (2020): Simultaneous synergistic effects of graphite addition and co-digestion of food waste and cow manure: Biogas production and microbial community. - Bioresource Technology 309: 123365.

[63] Hasegawa, S., Shiota, N., Katsura, K., Akashi, A. (2000): Solubilization of organic sludge by thermophilic aerobic bacteria as a pretreatment for anaerobic digestion. - Water Science and Technology 41(3): 163-169. 
[64] Hegde, S., Trabold, T. A. (2019): Anaerobic digestion of food waste with unconventional co-substrates for stable biogas production at high organic loading rates. - Sustainability 11: $1-15$.

[65] Holliger, C., Alves, M., Andrade, D., Angelidaki, I., Astals, S., Baier, U., Bougrier, C. (2016): Towards a standardization of biomethane potential tests. - Water Science Technology 74(11): 2515-2522.

[66] Horiuchi, J. I., Shimizu, T., Tada, K., Kanno, T., Kobayashi, M. (2002): Selective production of organic acids in anaerobic acid reactor by $\mathrm{pH}$ control. - Bioresource Technology 82: 209-213.

[67] Ibrahim, N., Yusoff, M. S., Aziz, H. A. (2010): Food waste characteristics after autoclaving treatment. - Proceedings $2^{\text {nd }}$ International Conference on Biotechnology and Food Science (IPCBEE), Singapore.

[68] Imachi, H., Sakai, S., Ohashi, A., Harada, H., Hanada, S., Kamagata, Y., Sekiguchi, Y. (2007): Pelotomaculum propionicicum sp. nov., an anaerobic, mesophilic, obligately syntrophic, propionate-oxidizing bacterium. - International Journal of Systematic and Evolutionary Microbiology 57(Pt7): 1487-1492.

[69] Izumi, K., Okishio, Y., Nagao, N., Niwa, C., Yamamoto, S., Toda, T. (2010): Effects of particle size on anaerobic digestion of food waste. - International Biodeterioration \& Biodegradation 64(7): 601-608.

[70] Jabeen, M., Zeshan Yousaf, S., Rizwan Haider, M., Malik, R. N. (2015): High-solids anaerobic co-digestion of food waste and rice husk at different organic loading rates. International Biodeterioration \& Biodegradation 102: 149-153.

[71] Jain, S., Jain, S., Wolf, I. T., Lee, J., Tong, Y. W. (2015): A comprehensive review on operating parameters and different pretreatment methodologies for anaerobic digestion of municipal solid waste. - Renewable and Sustainable Energy Reviews 52: 142-154.

[72] Jang, H. M., Ha, J. H., Park, J. M., Kim, M. S., Sommer, S. G. (2015): Comprehensive microbial analysis of combined mesophilic anaerobicethermophilic aerobic process treating high-strength food wastewater. - Water Research 73: 291-303.

[73] Jang, S., Kim, D. H., Yun, Y. M., Lee, M. K., Moon, C., Kang, W. S., Kwak, S. S., Kim, M. S. (2015): Hydrogen fermentation of food waste by alkali shock pretreatment: microbial community analysis and limitation of continuous operation. - Bioresource Technology 186: $215-222$.

[74] Jayaraj, S., Deepanraj, B., Sivasubramanian, V. (2014): Study on the effect of ph on biogas production from food waste by anaerobic digestion. $-9^{\text {th }}$ Annual Green Energy Conference in (IGEC-IX), Tianjin China, May 2014.

[75] Jiang, J., Li, L., Cui, M., Zhang, F., Liu, Y., Liu, Y., Long, J., Guo, Y. (2018): Anaerobic digestion of kitchen waste: The effects of source, concentration, and temperature. Biochemical Engineering Journal 135: 91-97.

[76] Jin, Y., Li, Y., Li, J. (2016): Influence of thermal pretreatment on physical and chemical properties of kitchen waste and the efficiency of anaerobic digestion. - Journal of Environmental Management 180: 291-300.

[77] Jin, C., Sun, S., Yang, D., Sheng, W., Ma, Y., He, W., Li, G. (2021): Anaerobic digestion: An alternative resource treatment option for food waste in China. - Science of the Total Environment 779: 146397.

[78] Jung, K. K., Baek, R. O., Young, N. C., Si, W. K. (2006): Effects of temperature and hydraulic retention time on anaerobic digestion of food waste. - Journal of Bioscience and Bioengineering 102(4): 328-332.

[79] Junoh, H., Yip, C. H., Kumaran, P. (2016): Effect on $\mathrm{Ca}(\mathrm{OH})_{2}$ pretreatment to enhance biogas production of organic food waste. - IOP Conf. Series: Earth and Environmental Science 32: 012013.

[80] Kamaruddin, M. A., Yusoff, M. S., Rui, L. M., Isa, A. M., Zawawi, M. H., Alrozi, R. (2017): An overview of municipal solid waste management and landfill leachate treatment: 
Malaysia and Asian perspectives. - Environmental Science and Pollution Research 24(35): 26988-27020.

[81] Kaparaju, P., Buendia, I., Ellegaard, L., Angelidaki, I. (2008): Effects of mixing on methane production during thermophilic anaerobic digestion of manure: lab-scale and pilot-scale studies. - Bioresource Technology 99: 4919-4928.

[82] Karim, K., Hoffmann, R., Klasson, K. T., Al-Dahhan, M. H. (2005): Anaerobic digestion of animal waste: effect of mode of mixing. - Water Research 39: 3597-3606.

[83] Kariyama, I. D., Zhai, X., Wu, B. (2018): Influence of mixing on anaerobic digestion efficiency in stirred tank digesters: A review. - Water Research 143: 503-517.

[84] Karki, R., Chuenchart, W., Surendra, K. C., Shrestha, S., Raskin, L., Sung, S., Hashimoto, A., Khanal, S. K. (2021): Anaerobic co-digestion: Current status and perspectives. Bioresource Technology 330: 125001.

[85] Karouach, F., Bakraoui, M., Gnaoui, Y. E., Lahboubi, N., Bari, H. E. (2020): Effect of combined mechanical-ultrasonic pretreatment on mesophilic anaerobic digestion of household organic waste fraction in Morocco. - Energy Reports 6: 310-314.

[86] Karthikeyan, O. P., Nguyen Hao, H. T., Razaghi, A., Heimann, K. (2018): Recycling of food waste for fuel precursors using an integrated bio-refinery approach. - Bioresource Technology 248: 194-198.

[87] Kawai, M., Nagao, N., Tajima, N., Niwa, C., Matsuyama, T., Toda, T. (2014): The effect of the labile organic fraction in food waste and the substrate/inoculum ratio on anaerobic digestion for a reliable methane yield. - Bioresource Technology 157: 174-180.

[88] Khan, M. U., Ahring, B. K. (2021): Improving the biogas yield of manure: Effect of pretreatment on anaerobic digestion of the recalcitrant fraction of manure. - Bioresource Technology 321: 124427.

[89] Kim, J., Lee, C. (2016): Response of a continuous anaerobic digester to temperature transitions: A critical range for restructuring the microbial community structure and function. - Water Research 89: 241-251.

[90] Kim, M., Abdulazeez, M., Haroun, B. M., Nakhlaa, G., Kelemanc, M. (2019): Microbial communities in co-digestion of food wastes and wastewater Biosolids. - Bioresource Technology 289: 121580.

[91] Kiran, E. U., Trzcinski, A. P., Liu, Y. (2015): Enhancing the hydrolysis and methane production potential of mixed food waste by an effective enzymatic pretreatment. Bioresource Technology 183: 47-52.

[92] Kondusamy, D., Kalamdhad, A. S. (2014): Pretreatment and anaerobic digestion of food waste for high rate methane production - A review. - Journal of Environmental Chemical Engineering 2(3): 1821-1830.

[93] Kouzi, A. I., Puranen, M., Kontro, M. H. (2020): Evaluation of the factors limiting biogas production in full-scale processes and increasing the biogas production efficiency. Environmental Science and Pollution Research 27: 28155-28168.

[94] Kumar, A., Samadder, S. R. (2020): Performance evaluation of anaerobic digestion technology for energy recovery from organic fraction of municipal solid waste: A review. - Energy 197: 117253.

[95] Kumar, M., Dutta, S., You, S., Luo, G., Zhang, S., Show, P. L., Sawarkar, A. D., Singh, Tsang, D. C. W. (2021): A critical review on biochar for enhancing biogas production from anaerobic digestion of food waste and sludge. - Journal of Cleaner Production 305: 127143.

[96] Kuruti, K., Begum, S., Ahuja, S., Rao Anupoju, G., Juntupally, S., Gandu, B., Kumar Ahuja, D. (2017): Exploitation of rapid acidification phenomena of food waste in reducing the hydraulic retention time (HRT) of high rate anaerobic digester without conceding on biogas yield. - Bioresource Technology 226: 65-72.

[97] Labatut, R. A., Angenent, L. T., Scott, N. R. (2011): Biochemical methane potential and biodegradability of complex organic substrates. - Bioresource Technology 102(3): 22552264. 
[98] Lee, D. H., Behera, S. K., Kim, J. W., Park, H. S. (2009): Methane production potential of leachate generated from Korean food waste recycling facilities: a lab-scale study. - Waste Management 29(2): 876-882.

[99] Lee, D. J., Lee, S. Y., Bae, J. S., Kang, J. G., Kim, K. H., Rhee, S. S., Park, J. H., Cho, J. S., Chung, J., Seo, D. C. (2015): Effect of volatile fatty acid concentration on anaerobic degradation rate from field anaerobic digestion facilities treating food waste leachate in South Korea. - Journal of Chemistry: 640717.

[100] Leung, D. Y. C., Wang, J. (2016): An overview on biogas generation from anaerobic digestion of food waste. - International Journal of Green Energy 13: 119-131.

[101] Li, L., He, Q., Wei, Y., He, Q., Peng, X. (2014): Early warning indicators for monitoring the process failure of anaerobic digestion system of food waste. - Bioresource Technology 171: 491-494.

[102] Li, L., He, Q., Ma, Y., Wang, X., Peng, X. (2015): Dynamics of microbial community in a mesophilic anaerobic digester treating food waste: Relationship between community structure and process stability. - Bioresource Technology 189: 113-120.

[103] Li, Y. Y., Jin, Y. Y. (2015): Effects of thermal pretreatment on acidification phase during two-phase batch anaerobic digestion of kitchen waste. - Renewable Energy 77: 550-557.

[104] Li, Y., Jin, Y., Li, J. (2016): Enhanced split-phase resource utilization of kitchen waste by thermal pre-treatment. - Energy 98: 155-167.

[105] Li, Y., Jin, Y., Li, J., Li, H., Yu, Z., Nie, Y. (2017): Effects of thermal pretreatment on degradation kinetics of organics during kitchen waste anaerobic digestion. - Energy 118: 377-386.

[106] Li, L., Peng, X., Wang, X., Wu, D. (2018): Anaerobic digestion of food waste: A review focusing on process stability. - Bioresource Technology 248: 20-28.

[107] Li, Q., Xu, M., Wang, G., Chen, R., Qiao, W., Wang, X. (2018): Biochar assisted thermophilic co-digestion of food waste and waste activated sludge under high feedstock to seed sludge ratio in batch experiment. - Bioresource Technology 249: 1009-1016.

[108] Li, L., Kong, Z., Qin, Y., Wu, J., Zhu, A., Xiao, B., Ni, J., Kubota, K., Li, Y. Y. (2020): Temperature-phased anaerobic co-digestion of food waste and paper waste with and without recirculation: Biogas production and microbial structure. - Science of the Total Environment 724: 138168.

[109] Lim, J. W., Chen, C. L., Ho, I. J. R., Wang, J. Y. (2013): Study of microbial community and biodegradation efficiency for single and two-phase anaerobic co-digestion of brown water and food waste. - Bioresource Technology 147: 193-201.

[110] Lim, J. W., Wen, S., Wong, K., Dai, Y., Tong, Y. W. (2020): Effect of seed sludge source and start-up strategy on the performance and microbial communities of thermophilic anaerobic digestion of food waste. - Energy 203: 117922.

[111] Lindmark, J., Eriksson, P., Thorin, E. (2014): The effects of different mixing intensities during anaerobic digestion of the organic fraction of municipal solid waste. - Waste Management 34: 1391-1397.

[112] Liu, C. F., Yuan, X. Z., Zeng, G. M., Li, W. W., Li, J. (2008): Prediction of methane yield at optimum $\mathrm{pH}$ for anaerobic digestion of organic fraction of municipal solid waste. Bioresource Technology 99: 882-888.

[113] Liu, X., Li, R., Ji, M., Han, L. (2013): Hydrogen and methane production by co-digestion of waste activated sludge and food waste in the two-stage fermentation process: substrate conversion and energy yield. - Bioresource Technology 146: 317-323.

[114] Liu, X., Khalid, H., Amin, F. R., Ma, X., Li, X., Chen, C., Liu, G. (2018): Effects of hydraulic retention time on anaerobic digestion performance of food waste to produce methane as a biofuel. - Environmental Technology \& Innovation 11: 348-357.

[115] Liu, J., Wang, D., Yu, C., Jiang, J., Guo, M., Hantoko, D., Yana, M. (2021): A two-step process for energy-efficient conversion of food waste via supercritical water gasification: Process design, products analysis, and electricity evaluation. - Science of the Total Environment 752: 142331. 
[116] Lu, F., Hao, L., Zhu, M., Shao, L., He, P. (2012): Initiating methanogenesis of vegetable waste at low inoculum to substrate ratio: Importance of spatial separation. - Bioresource Technology 105: 169-173.

[117] Ma, C., Liu, J., Ye, M., Zou, L., Qian, G., Li, Y. Y. (2018): Towards utmost bioenergy conversion efficiency of food waste: Pretreatment, co-digestion, and reactor type. Renewable and Sustainable Energy Reviews 90: 700-709.

[118] Mamimin, C., Prasertsan, P., Kongjan, P., O-Thong, S. (2017): Effects of volatile fatty acids in biohydrogen effluent on biohythane production from palm oil mill effluent under thermophilic condition. - Electronic Journal of Biotechnology 29: 78-85.

[119] Mao, C., Feng, Y., Wang, X., Ren, G. (2015): Review on research achievements of biogas from anaerobic digestion. - Renewable and Sustainable Energy Reviews 45: 540-555.

[120] Mao, L., Zhang, J., Dai, Y., Tong, Y. W. (2019): Effects of mixing time on methane production from anaerobic co-digestion of food waste and chicken manure: Experimental studies and CFD analysis. - Bioresource Technology 294: 122177.

[121] Mata-Alvarez, J., Dosta, J., Romero-Güiza, M. S., Fonoll, X., Peces, M., Astals, S. (2014): A critical review on anaerobic co-digestion achievements between 2010 and 2013. Renewable \& Sustainable Energy Reviews 36: 412-427.

[122] Menon, A., Ren, F., Wang, J. Y., Giannis, A. (2016): Effect of pretreatment techniques on food waste solubilisation and biogas production during thermophilic batch anaerobic digestion. - Journal Material Cycles Waste Management 18: 222-230.

[123] Micolucci, F., Gottardo, M., Bolzonella, D., Pavan, P. (2014): Automatic process control for stable bio-hythane production in two-phase thermophilic anaerobic digestion of food waste. - International Journal of Hydrogen Energy 39(31): 17563-17572.

[124] Nagao, N., Tajima, N., Kawai, M., Niwa, C., Kurosawa, N., Matsuyama, T., Yusoff, F. M., Toda, T. (2012): Maximum organic loading rate for the single-stage wet anaerobic digestion of food waste. - Bioresource Technology 118: 210-218.

[125] Naran, E., Toor, U. A., Kim, D. (2016): Effect of pretreatment and anaerobic co-digestion of food waste and waste activated sludge on stabilization and methane production. International Biodegradation and Biodeterioration 113: 17-21.

[126] Nathao, C., Sirisukpoka, U., Pisutpaisal, N. (2013): Production of hydrogen and methane by one and two stage fermentation of food waste. - International Journal of Hydrogen Energy 38(35): 15764-15769.

[127] Negri, C., Ricci, M., Zilio, M., D’Imporzano, G., Qiao, W., Dong, R., Adani, F. (2020): Anaerobic digestion of food waste for bio-energy production in China and Southeast Asia: A review. - Renewable and Sustainable Energy Reviews 133: 110138.

[128] Neshat, S. A., Mohammadi, M., Najafpour, G. D., Lahijani, P. (2017): Anaerobic codigestion of animal manures and lignocellulosic residues as a potent approach for sustainable biogas production. - Renewable and Sustainable Energy Reviews 79: 308-322.

[129] Nghiem, L. D., Koch, K., Bolzonella, D., Drewes, J. E. (2017): Full scale co-digestion of wastewater sludge and food waste: Bottlenecks and possibilities. - Renewable and Sustainable Energy Reviews 72: 354-362.

[130] Nguyen, D. C., Yeop, J. S., Choi, J., Kim, S., Chang, S. W., Jeon, B. H., Guo, W., Ngo, H. H. (2017): A new approach for concurrently improving performance of South Korean food waste valorization and renewable energy recovery via dry anaerobic digestion under mesophilic and thermophilic conditions. - Waste Management 66: 161-168.

[131] Nielsen, H., Uellendahl, H., Ahring, B. (2007): Regulation and optimization of the biogas process: propionate as a key parameter. - Biomass Bioenergy 31(11-12): 820-830.

[132] Noyola, A., Tinajero, A. (2005): Effect of biological additives and micronutrients on the anaerobic digestion of physicochemical sludge. - Water Science and Technology 52(1-2): 275-281.

[133] Oladejo, O. S., Dahunsi, S. O., Adesulu-Dahunsi, A. T., Ojo, S. O., Lawal, A. I., Idowu, E. O., Olanipekun, A. A., Ibikunle, R. A., Osueke, C. O., Ajayi, O. E., Osueke, N., 
Evbuomwan, I. (2020): Energy generation from anaerobic co-digestion of food waste, cow dung and piggery dung. - Bioresource Technology 313: 123694.

[134] Ormaechea, P., Castrillon, L., Suarez-Pena, B., Megido, L., Fernandez-Nava, Y., Negral, L., Maranon, E., Rodriguez-Iglesias, J. (2018): Enhancement of biogas production from cattle manure pretreated and/or co-digested at pilot-plant scale, characterization by SEM. - Renewable Energy 126: 897-904.

[135] Owamah, H. I., Izinyon, O. C. (2015): The effect of organic loading rates (OLRs) on the performances of food wastes and maize husks anaerobic co-digestion in continuous mode. - Sustainable Energy Technologies and Assessments 11: 71-76.

[136] Pagliaccia, P., Gallipoli, A., Gianico, A., Montecchio, D., Braguglia, C. M. (2016): Single stage anaerobic bioconversion of food waste in mono and co-digestion with olive husks: impact of thermal pretreatment on hydrogen and methane production. - International Journal of Hydrogen Energy 41(2): 905-915.

[137] Pan, S. Y., Tsai, C. Y., Liu, C. W., Wang, S. W., Kim, H., Fan, C. (2021): Anaerobic codigestion of agricultural wastes toward circular bio-economy. - iScience 24: 102704.

[138] Panigrahi, S., Dubey, B. K. (2019): A critical review on operating parameters and strategies to improve the biogas yield from anaerobic digestion of organic fraction of municipal solid waste. - Renewable Energy 143: 779-797.

[139] Panigrahi, S., Sharma, H. B., Dubey, B. K. (2020): Anaerobic co-digestion of food waste with pretreated yard waste: A comparative study of methane production, kinetic modeling and energy balance. - Journal of Cleaner Production 243: 118480.

[140] Parawira, W. (2004): Anaerobic treatment of agricultural residues and wastewater application of high- rate reactors. - PhD Thesis, Lund University. Retrieved from ttps://lup.lub.lu.se/search/ws/files/5606523/1472236.pdf.

[141] Paritosh, K., Kushwaha, S. K., Yadav, M., Pareek, N., Chawade, A., Vivekanand, V. (2017): Food waste to energy: an overview of sustainable approaches for food waste management and nutrient recycling. - BioMed Research International, Article ID: 2370927.

[142] Paudel, S., Kang, Y., Yoo, Y.-S., Seo, G. T. (2017): Effect of volumetric organic loading rate (OLR) on $\mathrm{H}_{2}$ and $\mathrm{CH}_{4}$ production by two-stage anaerobic co-digestion of food waste and brown water. - Waste Management 61: 484-493.

[143] Pecorini, I. Baldi, F., Carnevale, E. A., Corti, A. (2016): Biochemical methane potential tests of different autoclaved and microwaved lignocellulosic organic fractions of municipal solid waste. - Waste Management 56: 143-150.

[144] Pleissner, D., Kwan, T. H., Lin, C. S. (2014): Fungal hydrolysis in submerged fermentation for food waste treatment and fermentation feedstock preparation. - Bioresource Technology 158: 48-54.

[145] Polprasert, C. (2007): Organic Waste Recycling - Technology and Management. $-3^{\text {rd }}$ Edition. IWA Publishing.

[146] Qiang, H., Niu, Q., Chi, Y., Li, Y. (2013): Trace metals requirements for continuous thermophilic methane fermentation of high solid food waste. - Chemical Engineering Journal 222: 330-336.

[147] Qiao, W., Takayanagi, K., Niu, Q., Shofie, M., Li, Y. Y. (2013): Long-term stability of thermophilic co-digestion submerged anaerobic membrane reactor encountering high organic loading rate, persistent propionate and detectable hydrogen in biogas. Bioresource Technology 149: 92-102.

[148] Rasapoor, M., Ajabshirchi, Y., Adl, M., Abdi, R., Gharibi, A. (2016): The effect of ultrasonic pretreatment on biogas generation yield from organic fraction of municipal solid waste under medium solids concentration circumstance. - Energy Conversion and Management 119: 444-452.

[149] Ratanatamskul, C., Manpetch, P. (2016): Comparative assessment of prototype digester configuration for biogas recovery from anaerobic co-digestion of food waste and rain tree leaf as feedstock. - International Biodeterioration \& Biodegradation 113: 367-374. 
[150] Ren, Y., Yu, M., Wu, C., Wang, Q., Gao, M., Huang, Q., Liu, Y. (2018): A comprehensive review on food waste anaerobic digestion: Research updates and tendencies. - Bioresource Technology 247: 1069-1076.

[151] Sabri, R. M., Jahim, J. M., Takriff, M. S., Yunus, N., Trisakti, B. (2018): Comparison of methane production utilizing raw and acidogenic effluent coming from sago starch processing in anaerobic sequencing batch reactor (ASBR). - Jurnal Kejuruteraan SI 1(7): 27-36.

[152] Salihu, A., Alam, Z. (2016): Pretreatment methods of organic wastes for biogas production. - Journal of Applied Science 16(3): 124-137.

[153] Sarto, S., Hildayati, R., Syaichurrozi, I. (2019): Effect of chemical pretreatment using sulfuric acid on biogas production from water hyacinth and kinetics. - Renewable Energy 132: 335-350.

[154] Sawatdeenarunat, C., Saipa, S., Suaisom, P. (2021): Methane recovery from cassava starch wastewater via anaerobic digestion: Effect of inoculum source and kinetic study. - AsiaPacific Journal of Science and Technology 26(2): 1-9.

[155] Sen, B., Aravind, J., Kanmani, P., Lay, C. H. (2016): State of the art and future concept of food waste fermentation to bioenergy. - Renewable and Sustainable Energy Reviews 53: 547-557.

[156] Seon, J. Y., Lee, T., Lee, S. C., Pham, H. D., Woo, H. C., Song, M. (2014): Bacterial community structure in maximum volatile fatty acidsproduction from alginate in acidogenesis. - Bioresource Technology 157(1): 22-27.

[157] Seruga, P. (2021): The municipal solid waste management system with anaerobic digestion. - Energies 14: 2067.

[158] Shahriari, H., Warith, M., Hamoda, M., Kennedy, K. J. (2012): Anaerobic digestion of organic fraction of municipal solid waste combining two pretreatment modalities, high temperature microwave and hydrogen peroxide. - Waste Management 32: 41-52.

[159] Shen, F., Yuan, H., Pang, Y., Chen, S., Zhu, B., Zou, D., Liu, Y., Ma, J., Yu, L., Li, X. (2013): Performances of anaerobic co-digestion of fruit \& vegetable waste (FVW) and food waste (FW): single-phase vs. two-phase. - Bioresource Technology 144: 80-85.

[160] Shi, X. S., Dong, J. J., Yu, J. H., Yin, H., Hu, S. M., Huang, S. X. (2017): Effect of hydraulic retention time on anaerobic digestion of wheat straw in the semicontinuous continuous stirred-tank reactors. - BioMed Research International 2017: 2457805.

[161] Siddique, M. N. I., Abdul Munaim, M. S., Wahid, Z. (2016): Role of hydraulic retention time in enhancing bioenergy generation from petrochemical wastewater. - Journal of Cleaner Production 133: 504-510.

[162] Siddique, M. N. I., Wahid, Z. A. (2018): Achievements and perspectives of anaerobic codigestion: A review. - Journal of Cleaner Production 194: 359-371.

[163] Singh, B., Szamosi, Z., Simenfalvi, Z. (2020): Impact of mixing intensity and duration on biogas production in an anaerobic digester: A review. - Critical Reviews in Biotechnology 40(4): 508-521.

[164] Sousa, D. Z., Smidt, H., Alves, M. M., Stams, A. J. M. (2007): Syntrophomonas zehnderi sp. nov., an anaerobe that degrades long-chain fatty acids in co-culture with Methanobacterium formicicum. - International Journal of Systematic and Evolutionary Microbiology 57(Pt3): 609-615.

[165] Stabnikova, O., Liu, X. Y., Wang, J. Y. (2008): Digestion of frozen/thawed food waste in the hybrid anaerobic solid-liquid system. - Waste Management 28: 1654-1659.

[166] SWCorp News (2016): http://www.swcorp.gov.my/swcorpnews/2016/SWCorpNews7.pdf. - Accessed on 20/8/2016.

[167] Ta, D. T., Lin, C. Y., Ngoc Ta, T. M., Chu, C. Y. (2020): Biohythane production via singlestage fermentation using gel-entrapped anaerobic microorganisms: Effect of hydraulic retention time. - Bioresource Technology 317: 123986.

[168] Tampio, E., Ervasti, S., Paavola, T. (2014): Anaerobic digestion of autoclaved and untreated food waste. - Waste Management 34: 370-377. 
[169] Tanimu, I. M., Ghazi, T. I. M., Harun, M. R., Idris, A. (2014): Effect of carbon to nitrogen ratio of food waste on biogas methane production in a batch mesophilic anaerobic digester. - International Journal of Innovation, Management and Technology 5(2): 116-119.

[170] Tayyab, A., Ahmad, Z., Mahmood, T., Khalid, A., Qadeer, S., Mahmood, S., Andleeb, S., Anjum, M. (2019): Anaerobic co-digestion of catering food waste utilizing Parthenium hysterophorus as co-substrate for biogas production. - Biomass and Bioenergy 124: 74-82.

[171] Tchobanoglous, G., Burton, F. L., Stensel, H. D. (2003): Wastewater Engineering Treatment and Reuse. $-4^{\text {th }}$ Edition, Tata Mc Graw-Hill. New Delhi, India.

[172] Tong, J., Lu, X., Zhang, J., Angelidaki, I., Wei, Y. (2018): Factors influencing the fate of antibiotic resistance genes during thermochemical pretreatment and anaerobic digestion of pharmaceutical waste sludge. - Environmental Pollution 243: 1403-1413.

[173] Tran, D. (2017): Hydrodynamic cavitation applied to food waste anaerobic digestion. Master Thesis. Linkoping University. Retrieved from http://www.divaportal.org/smash/get/diva2:930482/fulltext01.pdf.

[174] Vavouraki, A. I., Angelis, E. M., Kornaros, M. (2013): Optimization of thermo-chemical hydrolysis of kitchen wastes. - Waste Management 33: 740-745.

[175] Ventura, J. R. S., Lee, J., Jahng, D. (2014): A comparative study on the alternating mesophilic and thermophilic two-stage anaerobic digestion of food waste. - Journal of Environmental Sciences 26(6): 1274-1283.

[176] Verma, S. (2002): Anaerobic digestion of biodegradable organics in municipal solid wastes. - Master Thesis. Columbia University. Retrieved from https://secureservercdn.net/198.71.233.199/epm.300.myftpupload.com/wpcontent/uploads/2020/10/Verma_thesis.pdf.

[177] Vijayaraghavan, K., Varma, V. S., Kamala Nalini, S. P. (2012): Hydrogen generation from biological solid waste of milk processing effluent treatment plant. - International Journal of Current Trends and Resources 1: 17-23.

[178] Voelklein, M. A., Jacob, A., O'Shea, R., Murphy, J. D. (2016): Assessment of increasing loading rate on two-stage digestion of food waste. - Bioresource Technology 202: 172180.

[179] Wang, M., Sun, X., Li, P., Yin, L., Liu, D., Zhang, Y., Li, W., Zheng, G. (2014): A novel alternate feeding mode for semi-continuous anaerobic co-digestion of food waste with chicken manure. - Bioresource Technology 164: 309-314.

[180] Wang, P., Wang, H., Qiu, Y., Ren, L., Jiang, B. (2018): Microbial characteristics in anaerobic digestion process of food waste for methane production-A review. - Bioresource Technology 248: 29-36.

[181] Wang, Z., Jiang, Y., Wang, S., Zhang, Y., Hu, Y., Hue, Z., Wu, G., Zhan, X. (2020): Impact of total solids content on anaerobic co-digestion of pig manure and food waste: Insights into shifting of the methanogenic pathway. - Waste Management 114: 96-106.

[182] Wu, B., Wang, X., Deng, Y. Y., He, X. L., Li, Z. W., Li, Q., Qin, H., Chen, J. T., He, M. X., Zhang, M., Hu, G. Q., Yin, X. B. (2016): Adaption of microbial community during the start-up stage of a thermophilic anaerobic digester treating food waste. - Bioscience, Biotechnology, and Biochemistry 80(10): 2025-2032.

[183] Wu, L.-J., Kobayashi, T., Kuramochi, H., Li, Y.-Y., Xu, K.-Q. (2016): Improved biogas production from food waste by co-digestion with de-oiled grease trap waste. - Bioresource Technology 201: 237-244.

[184] Xiao, B., Qin, Y., Zhang, W., Wu, J., Qiang, H., Liu, J., Li, Y. Y. (2018): Temperaturephased anaerobic digestion of food waste: A comparison with single-stage digestions based on performance and energy balance. - Bioresource Technology 249: 826-834.

[185] Yamada, T., Sekiguchi, Y., Hanada, S. (2006): Anaerolinea thermolimosa sp. nov., Levilinea saccharolytica gen. nov., sp. nov. and Leptolinea tardivitalis gen. nov., sp. nov., novel filamentous anaerobes, and description of the new classes Anaerolineae classis nov. and Caldilineae classis nov. in the bacterial phylum Chloroflexi. - International Journal of Systematic and Evolutionary Microbiology 56: 1331-1340. 
[186] Yang, L., Huang, Y., Zhao, M. (2015): Enhancing biogas generation performance from food wastes by high-solids thermophilic anaerobic digestion: effect of $\mathrm{pH}$ adjustment. International Biodeterioration and Biodegradation 105: 153-159.

[187] Yang, Z., Koh, S. K., Ng, W. C., Lim, R. C. J., Tan, H. T. W., Tong, Y. W., Wang, C. H. (2016): Potential application of gasification to recycle food waste and rehabilitate acidic soil from secondary forests on degraded land in Southeast Asia. - Journal of Environmental Management 172: 40-48.

[188] Yeshanew, M. M., Frunzo, L., Pirozzi, F., Lens, P. N. L., Esposito, G. (2016): Production of biohythane from food waste via an integrated system of continuously stirred tank and anaerobic fixed bed reactors. - Bioresource Technology 220: 312-322.

[189] Yin, Y., Liu, Y., Meng, S., Kiran, E. U., Liu, Y. (2016): Enzymatic pretreatment of activated sludge, food waste and their mixture for enhanced bioenergy recovery and waste volume reduction via anaerobic digestion. - Applied Energy 179: 1131-1137.

[190] Yirong, C., Heaven, S., Banks, C. J. (2015): Effect of a trace element addition strategy on volatile fatty acid accumulation in thermophilic anaerobic digestion of food waste. - Waste Biomass Valorization 6(1): 1-12.

[191] Yong, Z., Dong, Y., Zhang, X., Tan, T. (2015): Anaerobic co-digestion of food waste and straw for biogas production. - Renewable Energy 78: 527-530.

[192] Zaher, U., Cheong, D. Y., Wu, B., Chen, S. (2007): Producing energy and fertilizer from organic municipal solid wastes. - Olympia, WA: Department of Biological Systems Engineering, WSU. http://www.ecy.wa.gov/programs/ swfa/solidwastedata/.

[193] Zamanzadeh, M., Hagen, L. H., Svensson, K., Linjordet, R., Horn, S. J. (2016): Anaerobic digestion of food waste - effect of recirculation and temperature on performance and microbiology. - Water Research 96: 246-254.

[194] Zamanzadeh, M., Hagen, L. H., Svensson, K., Linjordet, R., Horn, S. J. (2017): Biogas production from food waste via co-digestion and digestion- effects on performance and microbial ecology. - Scientific Reports 7: 1-12.

[195] Zamri, M. F. M. A., Hasmady, S., Akhiar, A., Ideris, F., Shamsuddin, A. H., Mofijur, M., Fattah, I. M. R., Mahlia, T. M. I. (2021): A comprehensive review on anaerobic digestion of organic fraction of municipal solid waste. - Renewable and Sustainable Energy Reviews 137: 110637.

[196] Zhang, P., Chen, Y., Zhou, Q. (2009): Waste activated sludge hydrolysis and short-chain fatty acids accumulation under mesophilic and thermophilic conditions: effect of $\mathrm{pH}$. Water Research 43: 3735-3742.

[197] Zhang, L., Lee, Y. W., Jahng, D. (2011): Anaerobic co-digestion of food waste and piggery wastewater: focusing on the role of trace elements. - Bioresource Technology 102(8): 5048-5059.

[198] Zhang, C., Su, H., Tan, T. (2013a): Batch and semi-continuous anaerobic digestion of food waste in a dual solid-liquid system. - Bioresource Technology 145: 10-16.

[199] Zhang, Z. L., Zhang, L., Zhou, Y. L., Chen, J. C., Liang, Y. M., Wei, L. (2013b): Pilot scale operation of enhanced anaerobic digestion of nutrient-deficient municipal sludge by ultrasonic pretreatment and co-digestion of kitchen garbage. - Journal of Environmental Chemical Engineering 1(1-2): 73-78.

[200] Zhang, C., Su, H., Baeyens, J., Tan, T. (2014): Reviewing the anaerobic digestion of food waste for biogas production. - Renewable and Sustainable Energy Reviews 38: 383-392.

[201] Zhang, C., Su, H., Wang, Z., Tan, T., Qin, P. (2015): Biogas by semi-continuous anaerobic digestion of food waste. - Applied Biochemical Biotechnology 175: 3901-3914.

[202] Zhang, W., Wu, S., Guo, J., Zhou, J., Dong, R. (2015a): Performance and kinetic evaluation of semi-continuously fed anaerobic digesters treating food waste: role of trace elements. Bioresource Technology 178: 297-305.

[203] Zhang, W., Zhang, L., Li, A. (2015b): Anaerobic co-digestion of food waste with MSW incineration plant fresh leachate: process performance and synergistic effects. - Chemical Engineering Journal 259: 795-805. 
[204] Zhang, J., Lv, C., Tong, J., Liu, J., Liu, J., Yu, D., Wang, Y., Chen, M., Wei, Y. (2016): Optimization and microbial community analysis of anaerobic co-digestion of food waste and sewage sludge based on microwave pretreatment. - Bioresource Technology 200: 253261.

[205] Zhang, W., Lang, Q., Fang, M., Li, X., Bah, H., Dong, H., Dong, R. (2017): Combined effect of crude fat content and initial substrate concentration on batch anaerobic digestion characteristics of food waste. - Bioresource Technology 232: 304-312.

[206] Zhang, J., Loh, K. C., Li, W., Lim, J. W., Dai, Y., Tong, Y. W. (2017): Three-stage anaerobic digester for food waste. - Applied Energy 194: 287-295.

[207] Zhang, L., Loh, K. C., Zhang, J. (2018): Food waste enhanced anaerobic digestion of biologically pretreated yard waste: Analysis of cellulose crystallinity and microbial communities. - Waste Management 79: 109-119.

[208] Zhang, J., Hu, Q., Qu, Y., Dai, Y., He, Y., Wang, C. H., Tong, Y. W. (2020): Integrating food waste sorting system with anaerobic digestion and gasification for hydrogen and methane co-production. - Applied Energy 257: 113988.

[209] Zhang, S., Zou, L., Wan, Y., Ye, M., Ye, J., Li, Y. Y., Liu, J. (2020): Using an expended granular sludge bed reactor for advanced anaerobic digestion of food waste pretreated with enzyme: The feasibility and its performance. - Bioresource Technology 311: 123504.

[210] Zhou, M., Yan, B., Wong, J. W. C., Zhang, Y. (2018): Enhanced volatile fatty acids production from anaerobic fermentation of food waste: A mini-review focusing on acidogenic metabolic pathways. - Bioresource Technology 248: 68-78.

[211] Zou, L., Ma, C., Liu, J., Li, M., Ye, M., Qian, G. (2016): Pretreatment of food waste with high voltage pulse discharge towards methane production enhancement. - Bioresource Technology 222: 82-88. 